\title{
Molecular Rotors for the Detection of Chemical Warfare Agent Simulants
}

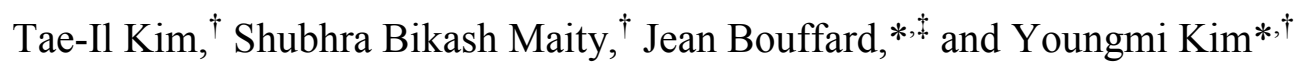 \\ ${ }^{\dagger}$ Department of Chemistry, Kyung Hee University, 26 Kyungheedae-ro, Dongdaemun-gu, Seoul, 02447, Korea. \\ ¿Department of Chemistry and Nano Science (BK 21 Plus), Ewha Womans University, 52 Ewhayeodae-gil, \\ Seodaemun-gu, Seoul, 03760, Korea. \\ youngmi.kim@khu.ac.kr \\ Tel: +82 2-961-9537 \\ Fax: +82 2-961-0443 \\ bouffard@ewha.ac.kr \\ Tel: +82 2-3277-3427 \\ Fax: +82 2-3277-3427
}

\section{Table of Contents:}

1. Synthesis of Compounds

2. Studies of the Photophysical Properties

3. Time-Resolved Photoluminescence Decay Dynamics

4. Stability Studies

5. DFT Calculations

6. Fluorometric Assay Studies

7. Identification of Reaction Product by LC-MS

8. ${ }^{1} \mathrm{H}-\mathrm{NMR}$ and ${ }^{13} \mathrm{C}-\mathrm{NMR}$ Spectra

9. References 


\section{Experimental}

\section{Materials}

All reagents were of the highest commercial quality and used as received without further purification. All solvents were spectroscopic grade unless otherwise noted. HPLC grade tetrahydrofuran, ethyl acetate, acetone, ethanol, acetonitrile, DMF and DMSO were obtained from Samchun Inc. Anhydrous dichloromethane and anhydrous acetonitrile, 4-dimethylaminopyridine (DMAP), and diethyl chlorophosphate (DCP) were obtained from Alfa Aesar. Silica gel $(40 \mu \mathrm{m})$ was obtained from Merck Inc. Aqueous solutions were freshly prepared with deionized water from a water purification system (Human Corp. Korea).

\section{General methods, instrumentation, and measurements}

Synthetic manipulations that required an inert atmosphere (where noted) were carried out under argon using standard Schlenk techniques. NMR $\left({ }^{1} \mathrm{H}\right.$ and $\left.{ }^{13} \mathrm{C}\right)$ spectra were recorded on JEOL $400 \mathrm{MHz}$ spectrometer. The ${ }^{1} \mathrm{H}$ and ${ }^{13} \mathrm{C}$ chemical shifts were reported as $\delta$ in units of parts per million (ppm), referenced to the residual solvent. Splitting patterns are denoted as s (singlet), d (doublet), t (triplet), q (quartet), m (multiplet), and br (broad). High-resolution electrospray ionization (ESI) mass spectra were obtained at the Korean National Center for Inter-University Research. Absorption spectra were obtained on a Shimadzu UV-2501 spectrophotometer. Fluorescence measurements were recorded on a Hitachi F-7000 fluorescence spectrophotometer using quartz cuvettes with a path length of $1 \mathrm{~cm}$. Fluorescence quantum yields were determined using fluorescein $\left(\Phi_{\mathrm{F}}=0.95\right.$ in $\left.0.1 \mathrm{~N} \mathrm{NaOH}\right)$ as standard. ${ }^{1}$ Life-time measurements were performed using a MicroTime-200 instrument at the Korea Basic Science Institute (KBSI), Daegu Center, South Korea. 


\section{Synthesis of Compounds}

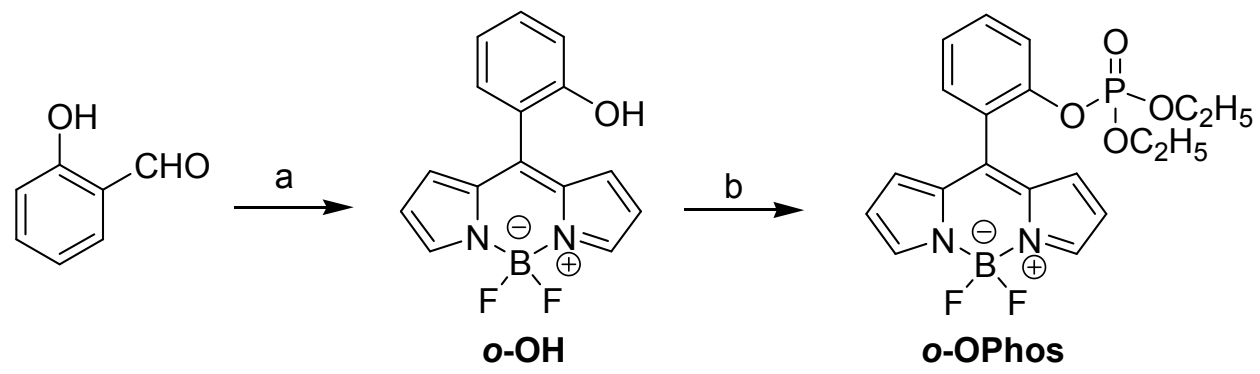

Scheme S1. Synthetic scheme for compounds $\boldsymbol{o}$-OH and $\boldsymbol{o}$-OPhos. (a) i) pyrrole, trifluoroacetic acid, r.t., 10 min; ii) $\mathrm{DDQ}, \mathrm{CH}_{2} \mathrm{Cl}_{2}$, r.t., 6 h; iii) $\mathrm{Et}_{3} \mathrm{~N}, \mathrm{BF}_{3} \cdot \mathrm{OEt}_{2}$, r.t., overnight, $25 \%$; (b) diethyl chlorophosphate, diisopropylethylamine, $\mathrm{CH}_{3} \mathrm{CN}$, overnight, $50{ }^{\circ} \mathrm{C}, 70 \%$.

8-[2-Hydroxyphenyl]-4,4-difluoro-4-bora-3a,4a-diaza-s-indacene $(\boldsymbol{o}-\mathrm{OH}) .{ }^{2}$ To a stirred mixture of pyrrole $(6.86 \mathrm{~g}, 102 \mathrm{mmol})$ and salicylaldehyde $(0.50 \mathrm{~g}, 4.1 \mathrm{mmol})$ at room temperature under an argon atmosphere were added 2 drops of trifluoroacetic acid. After the resulting mixture was stirred at room temperature for 10 minutes, the reaction was quenched with a solution of $0.1 \mathrm{M} \mathrm{NaOH}$, and extracted with ethyl acetate. The combined organic layers were dried over anhydrous $\mathrm{MgSO}_{4}$, filtered, and evaporated under reduced pressure. The crude mixture was purified by column chromatography on silica gel using progressively more polar 20:1 to 5:1 hexanes:ethyl acetate as the mobile phase to afford the dipyrromethane intermediate as a white solid. To a stirred solution of the dipyrromethane in dry $\mathrm{CH}_{2} \mathrm{Cl}_{2}(100 \mathrm{~mL})$ at room temperature under argon atmosphere was added DDQ (600 mg, $2.64 \mathrm{mmol})$. After stirring at room temperature for 6 hours, $\mathrm{Et}_{3} \mathrm{~N}$ ( $\left.4 \mathrm{~mL}, 28.8 \mathrm{mmol}\right)$ was added to the solution, followed by dropwise addition of $\mathrm{BF}_{3} \cdot \mathrm{OEt}_{2}(6 \mathrm{~mL}, 48.6 \mathrm{mmol})$. The resulting solution was stirred overnight. After the reaction was completed, the reaction solution was evaporated under reduced pressure. The crude product was purified by column chromatography on silica gel using progressively more polar 10:1 to 2:1 hexanes:ethyl acetate as the mobile phase to afford $\boldsymbol{o}-\mathbf{O H}$ as a red solid $(0.29 \mathrm{~g}, 25 \%)$.; ${ }^{1} \mathrm{H}-\mathrm{NMR}\left(400 \mathrm{MHz}, \mathrm{CDCl}_{3}\right): \delta=7.95(\mathrm{~s}, 2 \mathrm{H}), 7.45(\mathrm{t}, 1 \mathrm{H}, J=7.8 \mathrm{~Hz}), 7.29(\mathrm{~d}, 1 \mathrm{H}, J=7.6 \mathrm{~Hz}), 7.05(\mathrm{~m}, 2 \mathrm{H})$, $6.94(\mathrm{~d}, 2 \mathrm{H}, J=4.4 \mathrm{~Hz}), 6.54(\mathrm{~d}, 2 \mathrm{H}, J=4.4 \mathrm{~Hz}), 5.16(\mathrm{~s}, 1 \mathrm{H}) ;{ }^{13} \mathrm{C}-\mathrm{NMR}(100 \mathrm{MHz}, \mathrm{CDCl}): \delta=153.3,144.9$, $142.5,135.1,132.0,131.6,131.4,120.5,120.1,118.9,116.9$; HR-MS (ESI): calcd. for $\mathrm{C}_{15} \mathrm{H}_{11} \mathrm{BN}_{2} \mathrm{OF}_{2} \mathrm{Na}$ $[\mathrm{M}+\mathrm{Na}]^{+} 307.0830$, found 307.0883 .

8-[2-Diethylphosphoryloxyphenyl]-4,4-difluoro-4-bora-3a,4a-diaza-s-indacene (o-OPhos). To a solution of $\boldsymbol{o}$-OH $(0.12 \mathrm{~g}, 0.42 \mathrm{mmol})$ in $10 \mathrm{~mL}$ anhydrous acetonitrile was added diisopropylethylamine $(110 \mu \mathrm{L}, 0.63$ $\mathrm{mmol})$ and the mixture solution was warmed to $50^{\circ} \mathrm{C}$. Neat diethyl chlorophosphate $(190 \mu \mathrm{L}, 1.3 \mathrm{mmol})$ was added via syringe over a period of $15 \mathrm{~min}$ and the solution was kept at $50{ }^{\circ} \mathrm{C}$ overnight. The resulting reaction solution was evaporated under reduced pressure, and the crude mixture was dissolved in water. The aqueous layer were extracted with ethyl acetate $(50 \mathrm{~mL} \times 3)$ and the combined organic layers were dried over anhydrous $\mathrm{MgSO}_{4}$, filtered and evaporated under reduce pressure. The crude mixture was purified by column chromatography on silica gel using progressively more polar 10:1 to $1: 1$ hexanes:ethyl acetate as the mobile phase to afford $\boldsymbol{o}$-OPhos as a red solid $(0.124 \mathrm{~g}, 70 \%)$.; ${ }^{1} \mathrm{H}-\mathrm{NMR}\left(400 \mathrm{MHz}, \mathrm{CDCl}_{3}\right): \delta=7.92(\mathrm{~s}, 2 \mathrm{H}), 7.56$ $(\mathrm{m}, 2 \mathrm{H}), 7.41(\mathrm{~d}, 1 \mathrm{H}, J=7.6 \mathrm{~Hz}), 7.31(\mathrm{t}, 1 \mathrm{H}, J=7.6 \mathrm{~Hz}), 6.86(\mathrm{~d}, 2 \mathrm{H}, J=4 \mathrm{~Hz}), 6.51(\mathrm{~d}, 2 \mathrm{H}, J=4 \mathrm{~Hz})$, $3.88(\mathrm{~m}, 4 \mathrm{H}), 1.14(\mathrm{t}, 6 \mathrm{H}, J=7.2 \mathrm{~Hz}) ;{ }^{13} \mathrm{C}-\mathrm{NMR}\left(100 \mathrm{MHz}, \mathrm{CDCl}_{3}\right): \delta=148.5,144.7,142.4,135.5,131.7$, $131.6, \quad 125.4,125.3,124.6,120.6,118.7,64.8,64.7,15.8,15.7$; HR-MS (ESI): calcd. for $\mathrm{C}_{19} \mathrm{H}_{20} \mathrm{BN}_{2} \mathrm{O}_{4} \mathrm{~F}_{2} \mathrm{PNa}[\mathrm{M}+\mathrm{Na}]^{+} 443.1120$, found 443.1124 . 

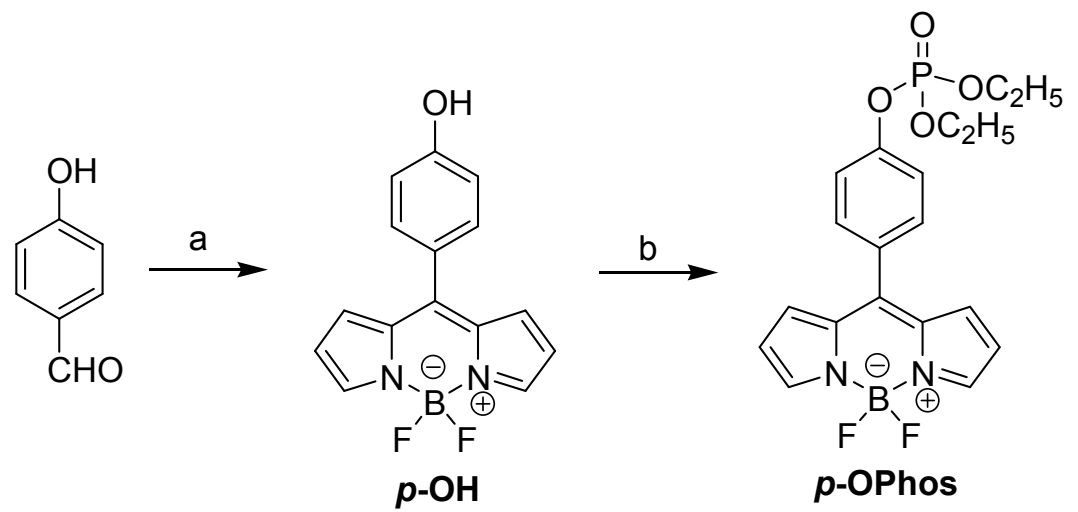

Scheme S2. Synthetic scheme for compounds $\boldsymbol{p}$-OH and $\boldsymbol{p}$-OPhos. (a) i) pyrrole, trifluoroacetic acid, r.t., $1 \mathrm{~h}$; ii) $\mathrm{DDQ}, \mathrm{CH}_{2} \mathrm{Cl}_{2}$, r.t., 6 h; iii) $\mathrm{Et}_{3} \mathrm{~N}, \mathrm{BF}_{3} \cdot \mathrm{OEt}_{2}$, r.t., overnight, $35 \%$; (b) diethyl chlorophosphate, $\mathrm{Et}_{3} \mathrm{~N} \mathrm{CH}_{3} \mathrm{CN}$, overnight, $50{ }^{\circ} \mathrm{C}, 51 \%$.

8-[4-Hydroxyphenyl]-4,4-difluoro-4-bora-3a,4a-diaza-s-indacene ( $\boldsymbol{p}$-OH). To a stirred mixture of pyrrole $(6.86 \mathrm{~g}, 102 \mathrm{mmol})$ and 4-hydroxybenzaldehyde $(0.5 \mathrm{~g}, 4 \mathrm{mmol})$ were added 2 drops of TFA under an argon atmosphere. After the resulting mixture was stirred at room temperature for 1 hour, the reaction was quenched with $0.1 \mathrm{M} \mathrm{NaOH}$, and extracted with ethyl acetate. The combined organic layers were dried over anhydrous $\mathrm{MgSO}_{4}$, filtered and evaporated under reduced pressure. The crude mixture was purified by column chromatography on silica gel using progressively more polar 20:1 to 5:1 hexanes:ethyl acetate as the mobile

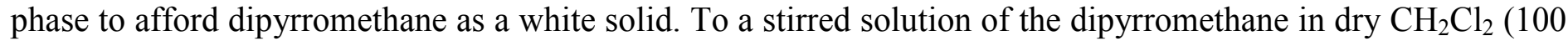
$\mathrm{mL})$ at room temperature under argon atmosphere was added DDQ $(600 \mathrm{mg}, 2.64 \mathrm{mmol})$. After stirring at room temperature for 6 hours, $\mathrm{Et}_{3} \mathrm{~N}(4 \mathrm{~mL}, 28.7 \mathrm{mmol})$ was added to the solution, followed by dropwise addition of $\mathrm{BF}_{3} \cdot \mathrm{OEt}_{2}(6 \mathrm{~mL}, 48.6 \mathrm{mmol})$. The resulting solution was stirred overnight. After the reaction was completed, the reaction solution was evaporated under reduced pressure. The crude product was purified by column chromatography on silica gel using progressively more polar 10:1 to 8:2 hexanes:ethyl acetate as the mobile phase to afford $\boldsymbol{p}$ - $\mathbf{O H}$ as a red solid $(0.4 \mathrm{~g}, 35 \%)$.; ${ }^{1} \mathrm{H}-\mathrm{NMR}\left(400 \mathrm{MHz}, \mathrm{CDCl}_{3}\right): \delta=7.92(\mathrm{~s}, 2 \mathrm{H}), 7.51(\mathrm{~d}, 2 \mathrm{H}$ $J=8.8 \mathrm{~Hz}), 6.98(\mathrm{t}, 4 \mathrm{H}, J=7.2 \mathrm{~Hz}), 6.55(\mathrm{~d}, 2 \mathrm{H}, J=4 \mathrm{~Hz}), 5.17(\mathrm{~s}, 1 \mathrm{H}) ;{ }^{13} \mathrm{C}-\mathrm{NMR}\left(100 \mathrm{MHz}, \mathrm{CDCl}_{3}\right): \delta=$ $158.4,147.4,143.6,134.9,132.7,131.5,126.5,118.4,115.7$; HR-MS (ESI): calcd. for $\mathrm{C}_{15} \mathrm{H}_{11} \mathrm{BN}_{2} \mathrm{OF}_{2} \mathrm{Na}$ $[\mathrm{M}+\mathrm{Na}]^{+} 307.0830$, found 307.0831 .

8-[4-Diethylphosphyloxyphenyl]-4,4-difluoro-4-bora-3a,4a-diaza-s-indacene ( $\boldsymbol{p}$-OPhos). To a solution of $\boldsymbol{p}$ $\mathbf{O H}(0.2 \mathrm{~g}, 0.7 \mathrm{mmol})$ in $15 \mathrm{~mL}$ anhydrous acetonitrile was added $\mathrm{Et}_{3} \mathrm{~N}(250 \mu \mathrm{L}, 1.8 \mathrm{mmol})$ and the resulting solution was warmed to $50^{\circ} \mathrm{C}$. Neat diethyl chlorophosphate $(305 \mu \mathrm{L}, 2.1 \mathrm{mmol})$ was added via syringe over a period of $10 \mathrm{~min}$ and the solution was kept at $50^{\circ} \mathrm{C}$ for overnight. The reaction solution was evaporated under reduced pressure and the crude mixture was dissolved in water. The aqueous layer was extracted with ethyl acetate $(50 \mathrm{~mL} \times 3)$ and the combined organic layers were dried over anhydrous $\mathrm{MgSO}_{4}$, filtered and evaporated under reduced pressure. The crude mixture was purified by column chromatography on silica gel using progressively more polar 10:1 to 1:1 hexanes:ethyl acetate as the mobile phase to afford $\boldsymbol{p}$-OPhos as a red solid (0.15 g, 51\%):; ${ }^{1} \mathrm{H}-\mathrm{NMR}\left(400 \mathrm{MHz}, \mathrm{CDCl}_{3}\right): \delta=7.95(\mathrm{~s}, 2 \mathrm{H}), 7.57(\mathrm{~d}, 2 \mathrm{H}, J=8.8 \mathrm{~Hz}), 7.40$ (d, $2 \mathrm{H}, J$ $=8 \mathrm{~Hz}), 6.93(\mathrm{~d}, 2 \mathrm{H}, J=4 \mathrm{~Hz}), 6.56(\mathrm{~d}, 2 \mathrm{H}, J=4 \mathrm{~Hz}), 4.28(\mathrm{~m}, 4 \mathrm{H}), 1.41(\mathrm{t}, 6 \mathrm{H}, J=7.6 \mathrm{~Hz}) ;{ }^{13} \mathrm{C}-\mathrm{NMR}$ $\left(100 \mathrm{MHz}, \mathrm{CDCl}_{3}\right): \delta=153.1,153.0,146.3,144.4,135.0,132.2,131.6,130.6,120.3,120.2,118.8,65.1$, 65.0, 16.3, 16.2; HR-MS (ESI): calcd. for $\mathrm{C}_{19} \mathrm{H}_{21} \mathrm{BN}_{2} \mathrm{O}_{4} \mathrm{~F}_{2} \mathrm{P}[\mathrm{M}+\mathrm{H}]^{+} 421.1300$, found 421.1300 . 


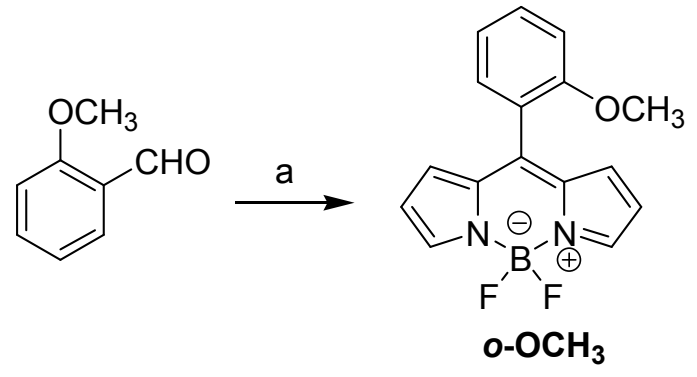

Scheme S3. Synthetic scheme for compound $\boldsymbol{o}-\mathbf{O C H}_{3}$. (a) i) pyrrole, trifluoroacetic acid, r.t., $1 \mathrm{~h}$; ii) DDQ, $\mathrm{CH}_{2} \mathrm{Cl}_{2}$, r.t., 6 h; iii) $\mathrm{Et}_{3} \mathrm{~N}, \mathrm{BF}_{3} \cdot \mathrm{OEt}_{2}$, r.t., overnight, $30 \%$

8-[2-Methoxyphenyl]-4,4-difluoro-4-bora-3a,4a-diaza-s-indacene $\left(\boldsymbol{o}-\mathbf{O C H}_{3}\right)$. To a stirred solution of 2methoxybenzaldehyde $(0.5 \mathrm{~g}, 3.67 \mathrm{mmol})$ and pyrrole $(6.16 \mathrm{~g}, 91.8 \mathrm{mmol})$ were added 2 drops of TFA under an argon atmosphere. After the resulting mixture was stirred at room temperature for 1 hour, the reaction was quenched with $0.1 \mathrm{M} \mathrm{NaOH}$ and extracted with ethyl acetate. The combined organic layers were dried over anhydrous $\mathrm{MgSO}_{4}$, filtered and evaporated under reduced pressure. The crude mixture was purified by column chromatography on silica gel using progressively more polar 20:1 to 5:1 hexanes:ethyl acetate as the mobile phase to afford the intermediate dipyrromethane as a light gray solid. The dipyrromethane was dissolved in dry $\mathrm{CH}_{2} \mathrm{Cl}_{2}(100 \mathrm{~mL})$ before the addition of DDQ $(500 \mathrm{mg}, 2.2 \mathrm{mmol})$ at room temperature under an argon atmosphere. After stirring at room temperature for 4 hours, $\mathrm{Et}_{3} \mathrm{~N}(4 \mathrm{~mL}, 28.7 \mathrm{mmol})$ was added to the solution, followed by dropwise addition of $\mathrm{BF}_{3} \cdot \mathrm{OEt}_{2}(6 \mathrm{~mL}, 48.6 \mathrm{mmol})$. The resulting solution was stirred overnight. After the completion of the reaction, the solvent was evaporated under reduced pressure. The crude mixture was purified by column chromatography on silica gel using progressively more polar 10:1 to 8:2 hexanes:ethyl acetate as the mobile phase to afford $\boldsymbol{o}-\mathbf{O C C H}_{3}$ as a red solid $(0.32 \mathrm{~g}, 30 \%)$; ${ }^{1} \mathrm{H}-\mathrm{NMR}\left(400 \mathrm{MHz}, \mathrm{CDCl}_{3}\right): \delta=$ $7.90(\mathrm{~s}, 2 \mathrm{H}), 7.50(\mathrm{t}, 1 \mathrm{H}, J=8.8 \mathrm{~Hz}), 7.30(\mathrm{~d}, 1 \mathrm{H}, J=6.4 \mathrm{~Hz}), 7.06(\mathrm{~m}, 2 \mathrm{H}), 6.80(\mathrm{~d}, 2 \mathrm{H}, J=4 \mathrm{~Hz}), 6.47$ (d, $2 \mathrm{H}, J=3.6 \mathrm{~Hz}), 3.75(\mathrm{~s}, 3 \mathrm{H}) ;{ }^{13} \mathrm{C}-\mathrm{NMR}\left(100 \mathrm{MHz}, \mathrm{CDCl}_{3}\right): \delta=157.3,144.7,144.0,135.8,131.8,131.7$, 131.3, 122.6, 120.3, 118.3, 111.5, 55.7; HR-MS (ESI): calcd. for $\mathrm{C}_{16} \mathrm{H}_{13} \mathrm{BN}_{2} \mathrm{OF}_{2} \mathrm{Na}[\mathrm{M}+\mathrm{Na}]^{+}$321.0987, found 321.0990 . 


\section{Studies of the Photophysical Properties}

Table S1. Photophysical properties of compounds in various solvents

\begin{tabular}{|c|c|c|c|c|c|}
\hline Compounds & Solvent & $\lambda_{\text {abs. } \max }[\mathrm{nm}]$ & $\varepsilon^{b}\left[\mathrm{M}^{-1} \mathrm{~cm}^{-1}\right]$ & $\lambda_{\text {em. } \max }{ }^{c}[\mathrm{~nm}]$ & $\Phi_{\mathrm{FL}}^{d}$ \\
\hline o-OH & THF & 503 & 59,000 & 522 & 0.07 \\
\hline$o-\mathrm{OH}$ & Ethyl acetate & 501 & 61,000 & 520 & 0.13 \\
\hline$o-\mathrm{OH}$ & Acetone & 500 & 54,000 & 518 & 0.06 \\
\hline$o-\mathrm{OH}$ & $\mathrm{C}_{2} \mathrm{H}_{5} \mathrm{OH}$ & 500 & 50,000 & 520 & 0.008 \\
\hline$o-\mathrm{OH}$ & $\mathrm{CH}_{3} \mathrm{CN}$ & 499 & 52,700 & 519 & 0.05 \\
\hline$o-\mathrm{OH}$ & DMF & 502 & 55,100 & 522 & 0.002 \\
\hline$o-\mathrm{OH}$ & DMSO & 504 & 62,000 & 525 & 0.002 \\
\hline$o-\mathrm{OH}$ & PBS buffer ${ }^{a}$ & 500 & 51,000 & 520 & 0.002 \\
\hline o-OPhos & $\mathrm{THF}$ & 507 & 67,500 & 525 & 0.51 \\
\hline o-OPhos & Ethyl acetate & 502 & 63,400 & 523 & 0.49 \\
\hline o-OPhos & Acetone & 502 & 53,000 & 523 & 0.44 \\
\hline o-OPhos & $\mathrm{C}_{2} \mathrm{H}_{5} \mathrm{OH}$ & 503 & 57,700 & 524 & 0.62 \\
\hline o-OPhos & $\mathrm{CH}_{3} \mathrm{CN}$ & 502 & 56,300 & 523 & 0.50 \\
\hline o-OPhos & DMF & 505 & 58,000 & 527 & 0.49 \\
\hline o-OPhos & DMSO & 507 & 60,000 & 530 & 0.13 \\
\hline o-OPhos & PBS buffer $^{a}$ & 504 & 54,100 & 524 & 0.83 \\
\hline p-OH & THF & 496 & 65,000 & 515 & 0.052 \\
\hline p-OH & Ethyl acetate & 495 & 60,000 & 514 & 0.039 \\
\hline p-OH & Acetone & 494 & 55,000 & 513 & 0.028 \\
\hline p-OH & $\mathrm{C}_{2} \mathrm{H}_{5} \mathrm{OH}$ & 494 & 53,000 & 513 & 0.029 \\
\hline p-OH & $\mathrm{CH}_{3} \mathrm{CN}$ & 494 & 55,000 & 513 & 0.028 \\
\hline p-OH & DMF & 496 & 56,000 & 517 & 0.009 \\
\hline p-OH & DMSO & 498 & 58,000 & 519 & 0.008 \\
\hline p-OH & PBS buffer ${ }^{a}$ & 494 & 47,000 & 514 & 0.007 \\
\hline$p$-OPhos & THF & 501 & 63,000 & 522 & 0.027 \\
\hline p-OPhos & Ethyl acetate & 499 & 67,000 & 520 & 0.022 \\
\hline p-OPhos & Acetone & 496 & 59,000 & 519 & 0.017 \\
\hline p-OPhos & $\mathrm{C}_{2} \mathrm{H}_{5} \mathrm{OH}$ & 500 & 70,000 & 522 & 0.027 \\
\hline p-OPhos & $\mathrm{CH}_{3} \mathrm{CN}$ & 498 & 60,000 & 519 & 0.018 \\
\hline p-OPhos & DMF & 501 & 58,000 & 524 & 0.023 \\
\hline p-OPhos & DMSO & 503 & 50,000 & 526 & 0.025 \\
\hline p-OPhos & PBS buffer $^{a}$ & 499 & 51,000 & 520 & 0.026 \\
\hline$o-\mathrm{OCH}_{3}$ & THF & 503 & 49,000 & 522 & 0.23 \\
\hline$o-\mathrm{OCH}_{3}$ & Ethyl acetate & 501 & 59,000 & 520 & 0.24 \\
\hline$o-\mathrm{OCH}_{3}$ & Acetone & 500 & 59,000 & 520 & 0.19 \\
\hline$o-\mathrm{OCH}_{3}$ & $\mathrm{C}_{2} \mathrm{H}_{5} \mathrm{OH}$ & 500 & 63,000 & 520 & 0.26 \\
\hline$o-\mathrm{OCH}_{3}$ & $\mathrm{CH}_{3} \mathrm{CN}$ & 499 & 50,000 & 519 & 0.15 \\
\hline$o-\mathrm{OCH}_{3}$ & DMF & 503 & 67,000 & 524 & 0.25 \\
\hline$o-\mathrm{OCH}_{3}$ & DMSO & 505 & 57,000 & 527 & 0.13 \\
\hline$o-\mathrm{OCH}_{3}$ & PBS buffer $^{a}$ & 501 & 48,000 & 521 & 0.007 \\
\hline
\end{tabular}

${ }^{a}$ Data were obtained in $10 \mathrm{mM}$ PBS buffer $(\mathrm{pH} 7.4)$ containing $1 \%$ DMF as cosolvent. ${ }^{b}$ Measured at each absorption maximum. ${ }^{c}$ Excited at $480 \mathrm{~nm} .{ }^{d}$ Quantum yields vs. Fluorescein in $0.1 \mathrm{~N} \mathrm{NaOH}\left(\Phi_{\mathrm{FL}}=0.95\right) .{ }^{1}$ 

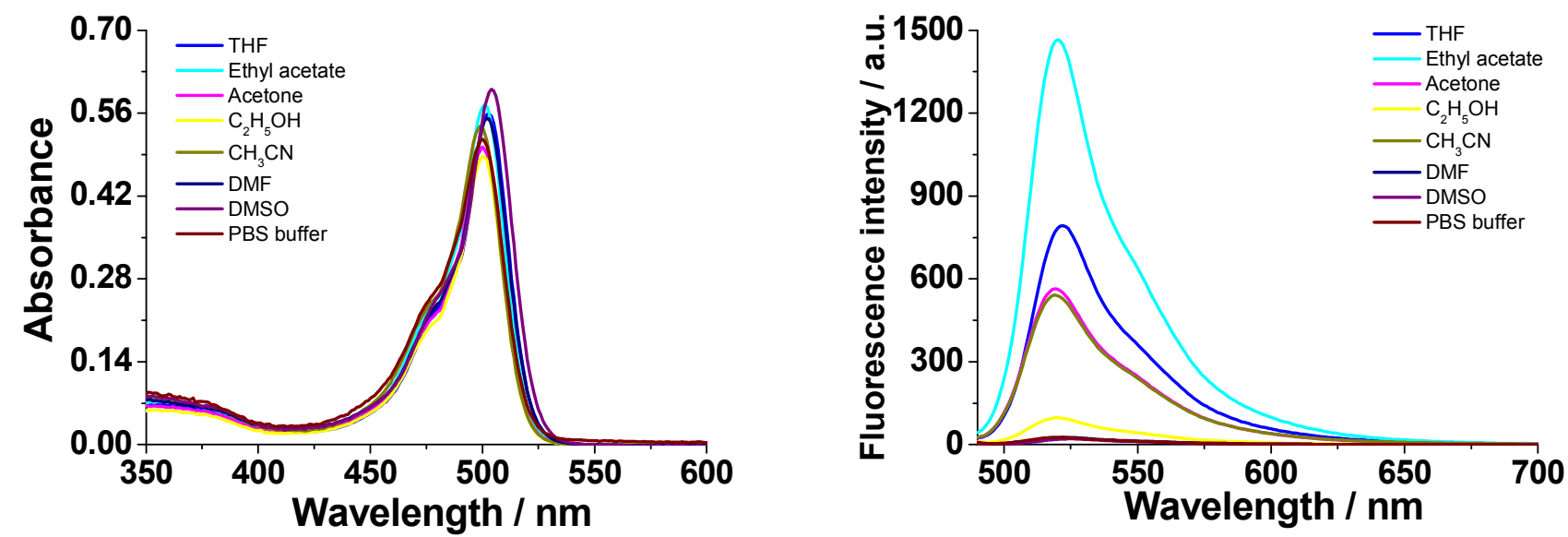

Figure S1. Absorption (left) and fluorescence emission (right) spectra of $\boldsymbol{o}-\mathbf{O H}(10 \mu \mathrm{M})$ in various solvents at $25^{\circ} \mathrm{C}$. Excited at $480 \mathrm{~nm}$.
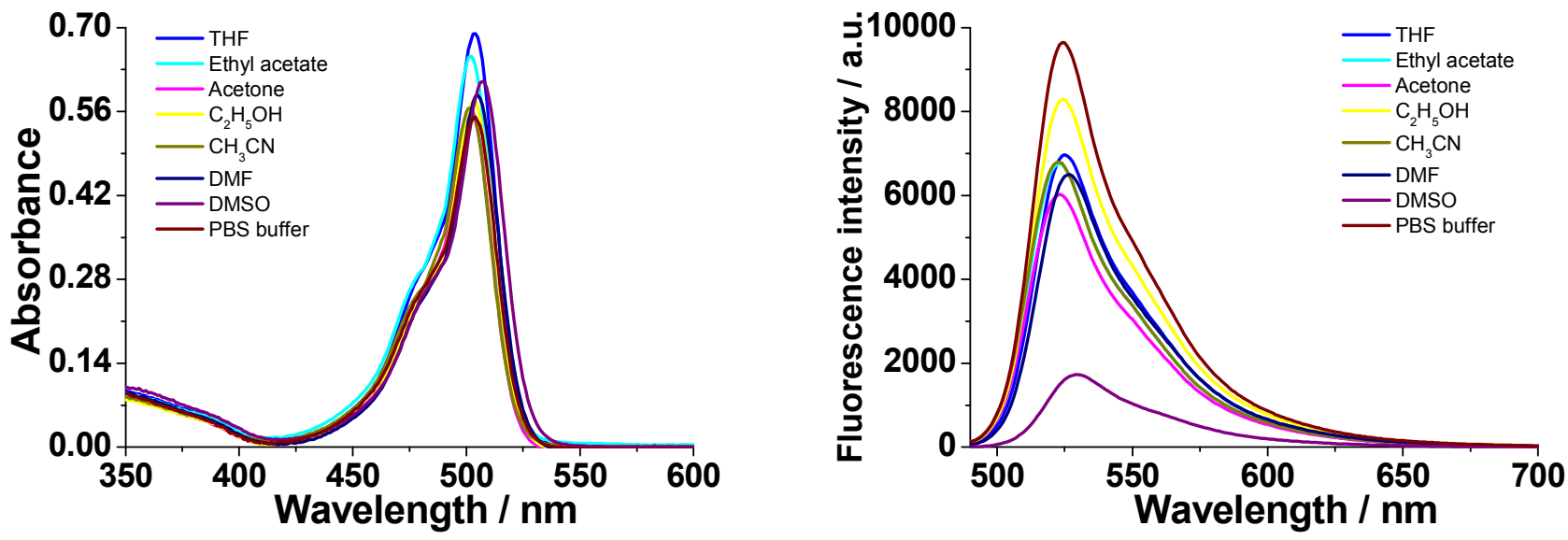

Figure S2. Absorption (left) and fluorescence emission (right) spectra of o-OPhos (10 $\mu \mathrm{M})$ in various solvents at $25{ }^{\circ} \mathrm{C}$. Excited at $480 \mathrm{~nm}$. 

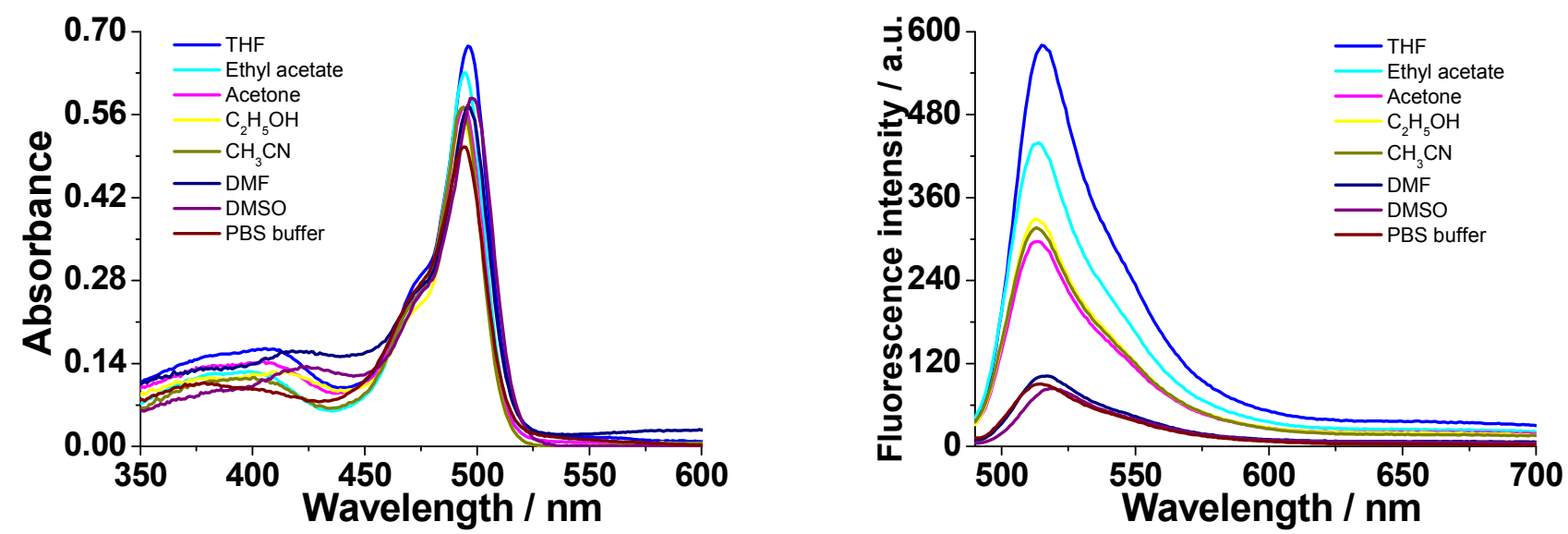

Figure S3. Absorption (left) and fluorescence emission (right) spectra of $\mathbf{p - O H}(10 \mu \mathrm{M})$ in various solvents at $25^{\circ} \mathrm{C}$. Excited at $480 \mathrm{~nm}$.
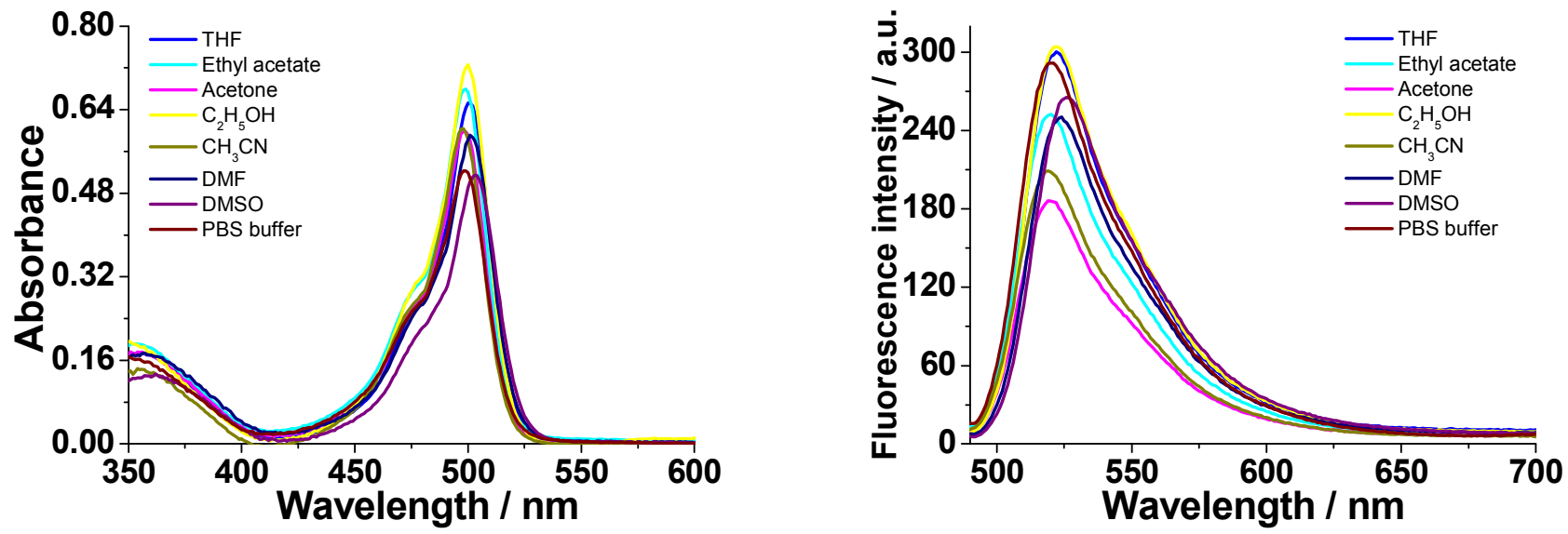

Figure S4. Absorption (left) and fluorescence emission (right) spectra of $\boldsymbol{p}$-OPhos $(10 \mu \mathrm{M})$ in various solvents at $25^{\circ} \mathrm{C}$. Excited at $480 \mathrm{~nm}$. 

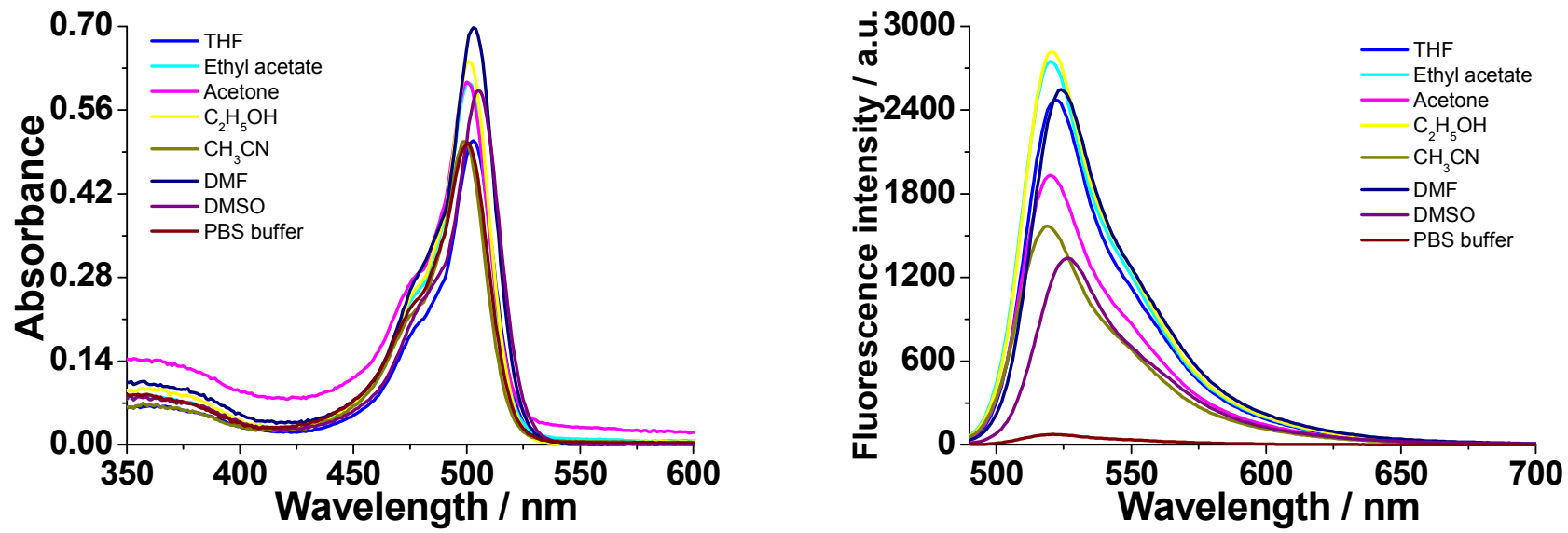

Figure S5. Absorption (left) and fluorescence emission (right) spectra of $\boldsymbol{o}-\mathbf{O C H}(10 \mu \mathrm{M})$ in various solvents at $25^{\circ} \mathrm{C}$. Excited at $480 \mathrm{~nm}$. 

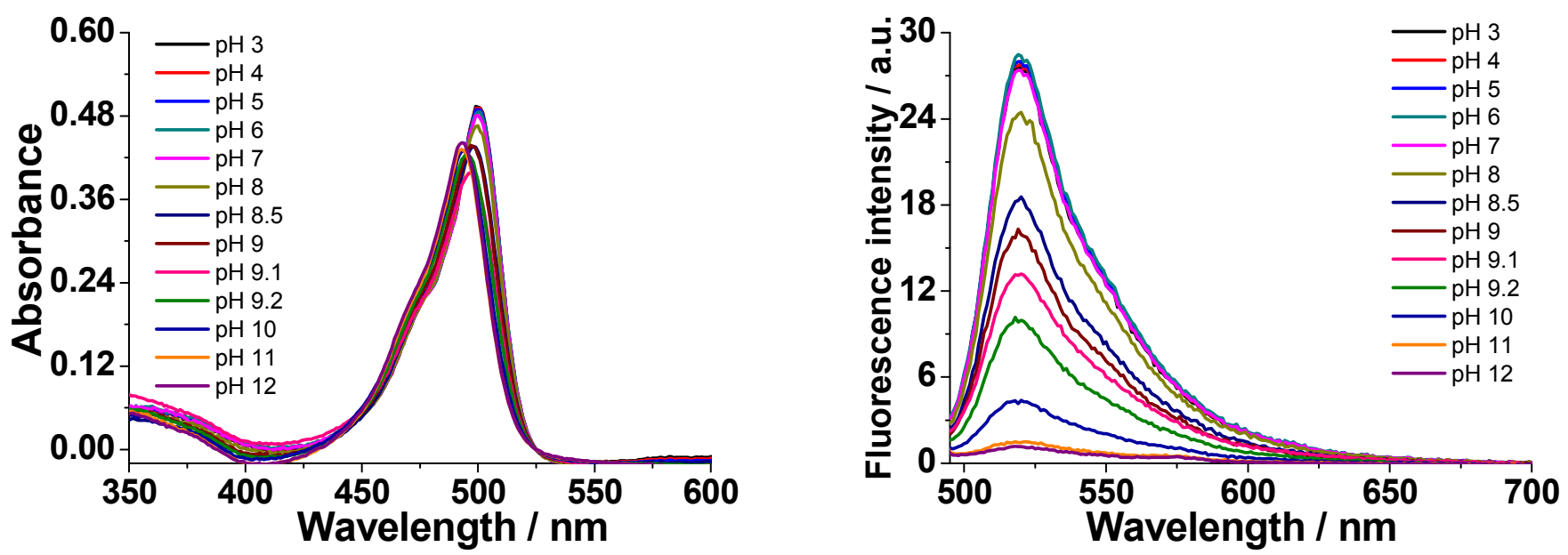

Figure S6. Absorption (left) and fluorescence emission (right) spectra of $\boldsymbol{o - O H}(10 \mu \mathrm{M})$ in different pH buffer systems containing $1 \%$ DMF as a cosolvent at $25^{\circ} \mathrm{C}$. Excited at $480 \mathrm{~nm}$.

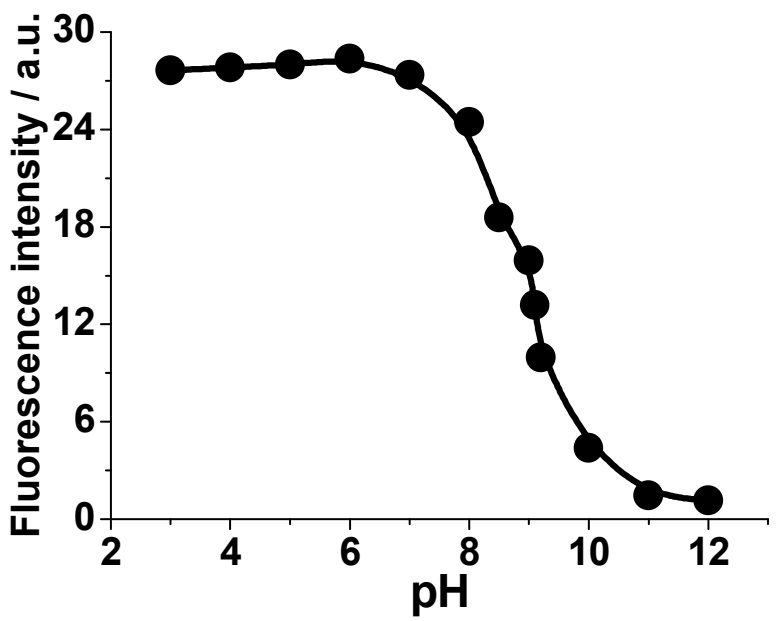

Figure S7. Relative fluorescence intensity at $520 \mathrm{~nm}$ of $\boldsymbol{o}-\mathbf{O H}$ in different pH conditions. $[\boldsymbol{o}-\mathbf{O H}]=10 \mu \mathrm{M}$. Excited at $480 \mathrm{~nm}$. $\mathrm{p} K_{\mathrm{a}}$ of compound $\boldsymbol{o}-\mathbf{O H}$ is estimated to be 9.1. 


\section{(c) Emission spectra of compounds in viscous media}

Because the luminescence of molecular rotors is dependent on the medium viscosity, the fluorescence spectra of meso-aryl BODIPYs were examined in ethanol-glycerol mixtures ranging from pure ethanol to 1:99 ethanol:glycerol. The viscosity of pure ethanol $(1.074 \mathrm{cP})$ and pure glycerol $(934 \mathrm{cP})$ at $25^{\circ} \mathrm{C}$ were taken from the CRC Handbook of Chemistry and Physics, 76th ed. The viscosity of intermediate mixtures was interpolated according to the Arrhenius model $(1),{ }^{3}$ which was experimentally demonstrated to be valid for BODIPY-based molecular rotors in methanol-glycerol: ${ }^{4}$

$\log \eta_{\text {mix }}=x_{1} \cdot \log \eta_{1}+x_{2} \cdot \log \eta_{2}$

$\eta$ : solvent viscosity

$x_{\mathrm{n}}$ : volume fractions of each solvent

The investigated solvent mixtures thus span a viscosity ranging from $1.07 \mathrm{cP}$ to $873 \mathrm{cP}$.

The calibration plot of fluorescence intensity $(I)$ versus viscosity $(\eta)$ were obtained based on the FörsterHoffmann equation $(2),{ }^{5}$ which relates the fluorescence quantum yield $\left(\Phi_{\mathrm{F}}\right)$ as a function of viscosity $(\eta)$ and fluorophore and condition-specific constants $(z, \alpha)$.

$$
\Phi_{\mathrm{F}}=\mathrm{z} \eta^{\alpha}
$$

Using the simplified relationship (3) derived from (2), ${ }^{6}$ we observed a linear relationship between the logarithms of fluorescence intensity $(I)$ and viscosity $(\eta)$ over the viscosity range investigated $(1.07-873 \mathrm{cP})$. The fluorescence intensity $(I)$ sharply increases as a function of the increasing viscosity $(\eta)$ for probe $\boldsymbol{o}-\mathbf{O H}$ $\left(x=0.23, R^{2}=0.9787\right)$, which is similar to those of control molecular rotors $\boldsymbol{p}$-OH $\left(x=0.25, R^{2}=0.9757\right)$ and $\boldsymbol{p}$-OPhos $\left(x=0.29, R^{2}=0.9744\right)$. Meanwhile, the DCP-induced bulkier product $\boldsymbol{o}$-OPhos, for which free rotation is restricted, was not affected by medium viscosity as indicated by a markedly lower value of slope $\left(x=0.026, R^{2}=0.9959\right)$.

$$
\log (I)=C+x \log (\eta)
$$

$I$ : fluorescence emission intensity

$\eta$ : solvent viscosity

$X$ : dye-dependent constant

$C$ : temperature-dependent constant 

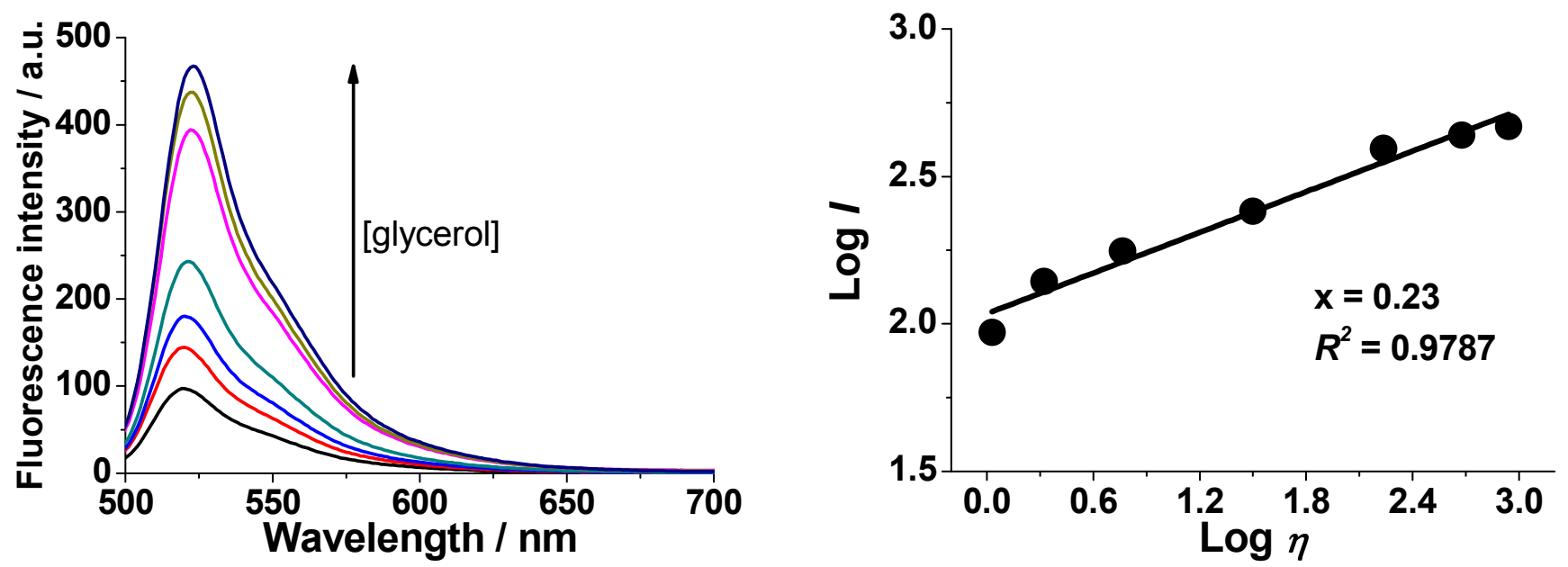

Figure S8. (left) Fluorescence emission spectra of $\boldsymbol{o - O H}(10 \mu \mathrm{M})$ in ethanol-glycerol mixtures with different glycerol fraction $\left(f_{\text {glycerol }}(\right.$ vol\%), bottom to top; $0,10,25,50,75,90,99 \%)$, which correspond to viscosity (bottom to top; 1.07, 2.11, 5.83, 31.7, 172, 475, $873 \mathrm{cP}$ ) at $25{ }^{\circ} \mathrm{C}$. Excited at $480 \mathrm{~nm}$. (right) Plot of Log (fluorescence intensity, $I$ ) as a function of $\log$ (viscosity, $\eta$ ).
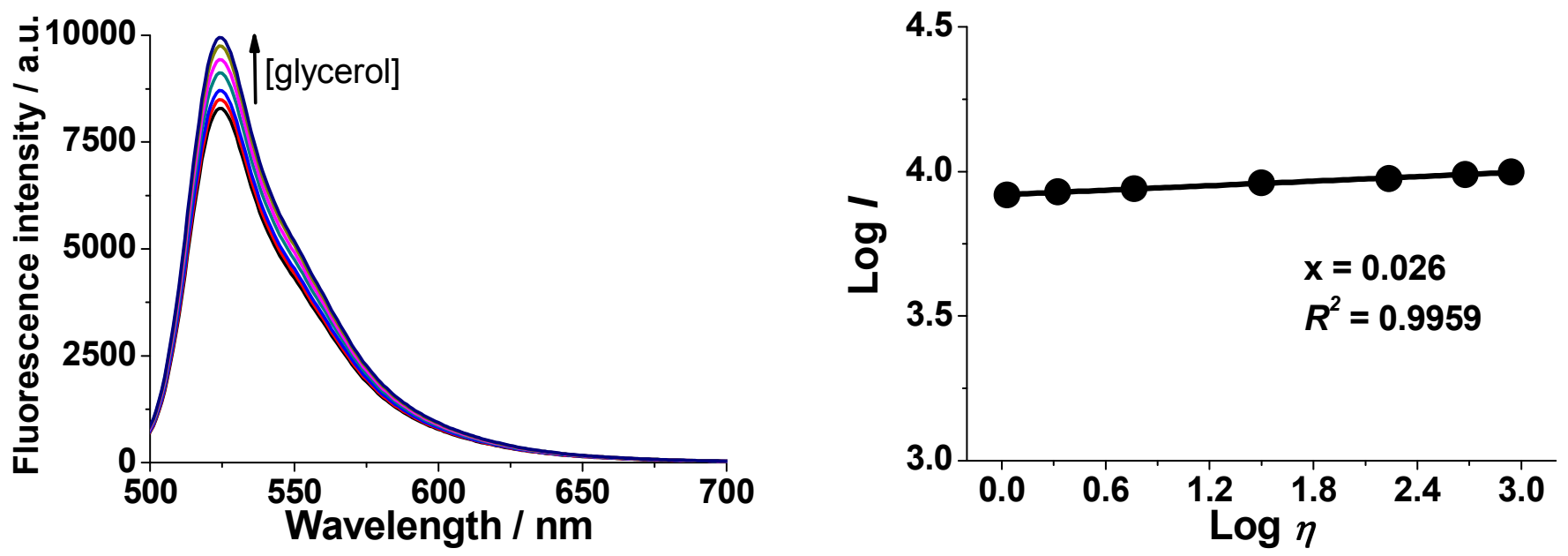

Figure S9. (left) Fluorescence emission (right) spectra of $\boldsymbol{o}$-OPhos $(10 \mu \mathrm{M})$ in ethanol-glycerol mixtures with different glycerol fraction $\left(f_{\text {glycerol }}(\mathrm{vol} \%)\right.$, bottom to top; $0,10,25,50,75,90,99 \%$ ), which correspond to viscosity (bottom to top; 1.07, 2.11, 5.83, 31.7, 172, 475, $873 \mathrm{cP}$ ) at $25{ }^{\circ} \mathrm{C}$. Excited at $480 \mathrm{~nm}$. (right) Plot of Log (fluorescence intensity, $I$ ) as a function of $\log$ (viscosity, $\eta$ ). 

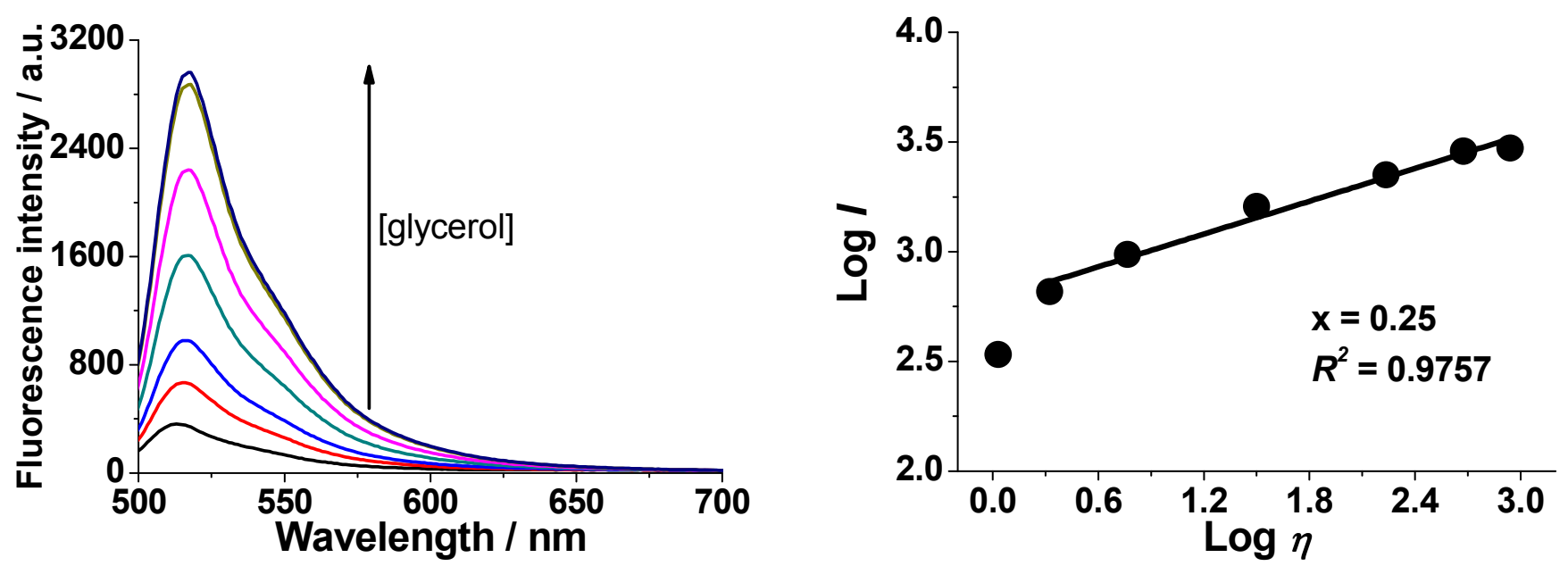

Figure S10. (left) Fluorescence emission (right) spectra of $\boldsymbol{p}$-OH $(10 \mu \mathrm{M})$ in ethanol-glycerol mixtures with different glycerol fraction $\left(f_{\text {glycerol }}(\mathrm{vol} \%)\right.$, bottom to top; $\left.0,10,25,50,75,90,99 \%\right)$, which correspond to viscosity (bottom to top; $1.07,2.11,5.83,31.7,172,475,873 \mathrm{cP}$ ) at $25^{\circ} \mathrm{C}$. Excited at $480 \mathrm{~nm}$. (right) Plot of $\log$ (fluorescence intensity, $I$ ) as a function of $\log$ (viscosity, $\eta$ ).
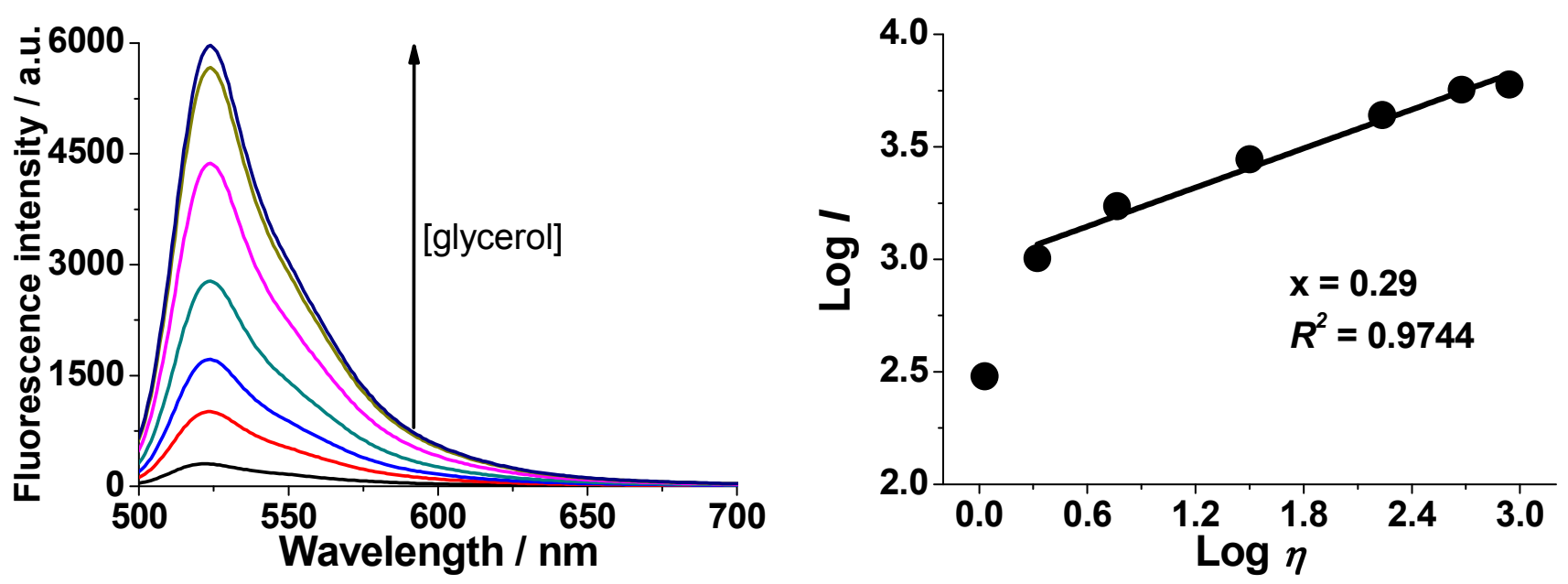

Figure S11. (left) Fluorescence emission (right) spectra of $\boldsymbol{p}$-OPhos $(10 \mu \mathrm{M})$ in ethanol-glycerol mixtures with different glycerol fraction $\left(f_{\text {glycerol }}(\mathrm{vol} \%)\right.$, bottom to top; $\left.0,10,25,50,75,90,99 \%\right)$, which correspond to viscosity (bottom to top; $1.07,2.11,5.83,31.7,172,475,873 \mathrm{cP}$ ) at $25^{\circ} \mathrm{C}$. Excited at $480 \mathrm{~nm}$. (right) Plot of $\log$ (fluorescence intensity, $I$ ) as a function of $\log$ (viscosity, $\eta$ ). 

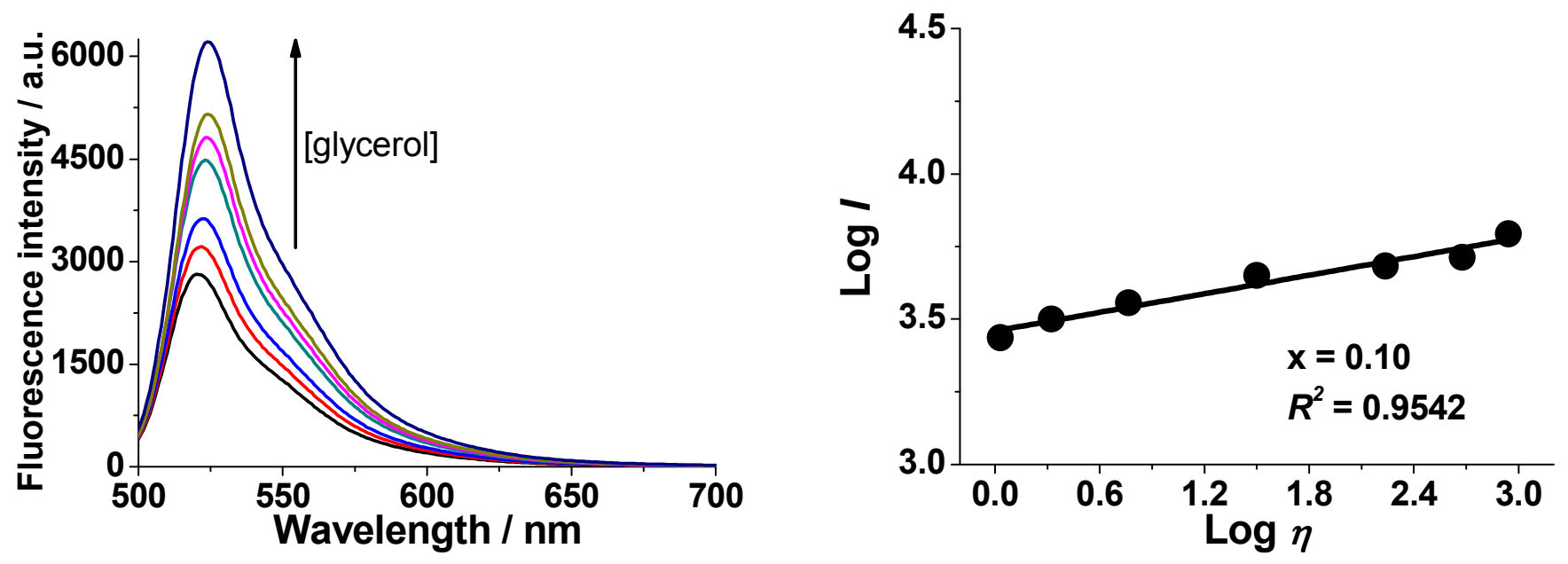

Figure S12. (left) Fluorescence emission (right) spectra of $\boldsymbol{o}-\mathbf{O C H}_{\mathbf{3}}(10 \mu \mathrm{M})$ in ethanol-glycerol mixtures with different glycerol fraction $\left(f_{\text {glycerol }}(\mathrm{vol} \%)\right.$, bottom to top; 0, 10, 25, 50, 75, 90, 99\%), which correspond to viscosity (bottom to top; 1.07, 2.11, 5.83, 31.7, 172, 475, $873 \mathrm{cP}$ ) at $25^{\circ} \mathrm{C}$. Excited at $480 \mathrm{~nm}$. (right) Plot of $\log$ (fluorescence intensity, $I$ ) as a function of $\log$ (viscosity, $\eta$ ). 


\section{Time-Resolved Photoluminescence Decay Dynamics}

Fluorescence lifetime decays were measured using an inverted-type scanning confocal microscope (MicroTime200, Picoquant, Germany) with a 20x objective. A $470 \mathrm{~nm}$ single-mode pulsed diode laser ( 100 ps pulse width) was used as an excitation source. A dichroic mirror (490 DCXR, AHF), a long-pass filter (HQ5001p, $\mathrm{AHF}$ ), a $50 \mu \mathrm{m}$ pinhole, and a single photon avalanche diode (PDM series, MPD) were used to collect emissions from the samples. Time-correlated single-photon counting technique was used to obtain fluorescence decay curves as a function of time with a resolution of 16 ps. Exponential fittings for the obtained fluorescence decays were performed by the iterative least-squares deconvolution fitting using the Symphotime software (version 5.3).

Table S2. Fluorescence decay of compounds

\begin{tabular}{|c|c|c|c|c|c|c|c|c|}
\hline Compound & Solvent & $\Phi_{\mathrm{FL}}^{b}$ & $\begin{array}{c}\tau_{1}\left(f_{1}\right)^{c} \\
{[\mathrm{~ns}]}\end{array}$ & $\begin{array}{c}\tau_{2}\left(f_{2}\right)^{c} \\
{[\mathrm{~ns}]}\end{array}$ & $\begin{array}{c}\tau_{3}\left(f_{3}\right)^{c} \\
{[\mathrm{~ns}]}\end{array}$ & $\begin{array}{l}\tau_{\text {avg }}{ }^{d} \\
{[\mathrm{~ns}]}\end{array}$ & $\begin{array}{c}k_{\mathrm{r}}^{e} \\
{\left[\mathrm{~s}^{-1}\right]}\end{array}$ & $\begin{array}{c}k_{\mathrm{nr}}^{f} \\
{\left[\mathrm{~s}^{-1}\right]}\end{array}$ \\
\hline \multirow[t]{3}{*}{$o-\mathrm{OH}$} & DMF & 0.002 & $0.04(0.659)$ & $0.21(0.34)$ & $4.53(0.0015)$ & 0.11 & $1.82 \times 10^{7}$ & $9.07 \times 10^{9}$ \\
\hline & EtOH & 0.008 & $0.19(0.996)$ & $1.02(0.004)$ & & 0.19 & $4.21 \times 10^{7}$ & $5.22 \times 10^{9}$ \\
\hline & Glycerol $^{a}$ & 0.04 & $0.62(0.66)$ & $1.29(0.34)$ & & 0.85 & $4.71 \times 10^{7}$ & $1.13 \times 10^{9}$ \\
\hline \multirow[t]{3}{*}{ o-OPhos } & DMF & 0.49 & $4.39(1)$ & & & 4.39 & $1.12 \times 10^{8}$ & $1.16 \times 10^{8}$ \\
\hline & $\mathrm{EtOH}$ & 0.62 & $4.51(1)$ & & & 4.51 & $1.37 \times 10^{8}$ & $8.43 \times 10^{7}$ \\
\hline & Glycerol $^{a}$ & 0.65 & $6.20(1)$ & & & 6.20 & $1.05 \times 10^{8}$ & $5.65 \times 10^{7}$ \\
\hline \multirow[t]{3}{*}{$p-\mathrm{OH}$} & DMF & 0.009 & $0.20(1)$ & & & 0.20 & $4.50 \times 10^{7}$ & $4.96 \times 10^{9}$ \\
\hline & $\mathrm{EtOH}$ & 0.029 & $0.32(1)$ & & & 0.32 & $9.06 \times 10^{7}$ & $3.03 \times 10^{9}$ \\
\hline & Glycerol $^{a}$ & 0.19 & $1.17(0.24)$ & $2.75(0.76)$ & & 2.37 & $8.02 \times 10^{7}$ & $3.42 \times 10^{8}$ \\
\hline \multirow[t]{3}{*}{ p-OPhos } & DMF & 0.023 & $0.27(1)$ & & & 0.27 & $8.52 \times 10^{7}$ & $3.62 \times 10^{9}$ \\
\hline & EtOH & 0.027 & $0.26(1)$ & & & 0.26 & $1.04 \times 10^{8}$ & $3.74 \times 10^{9}$ \\
\hline & Glycerol $^{a}$ & 0.48 & $4.98(1)$ & & & 4.98 & $9.64 \times 10^{7}$ & $1.04 \times 10^{8}$ \\
\hline
\end{tabular}

${ }^{a}$ Data were obtained in glycerol containing $1 \%$ EtOH. ${ }^{b}$ Quantum yields vs. Fluorescein in $0.1 \mathrm{~N} \mathrm{NaOH}\left(\Phi_{\mathrm{FL}}=0.95\right) .{ }^{1}$ ${ }^{c}$ Lifetime $(\tau)$ and fraction $(f)$ of shorter (1) and longer (2 and 3) lived species. ${ }^{d}$ The weighted mean lifetime. ${ }^{e} k_{\mathrm{r}}=\Phi_{\mathrm{FL}} / \tau .{ }^{f} k_{\mathrm{nr}}$ $=\left(1-\Phi_{\mathrm{FL}}\right) / \tau$.

In $\mathrm{EtOH}, \boldsymbol{o}-\mathbf{O H}$ shows a very short excited-state lifetime $\left(\tau_{\mathrm{av}} \sim 0.19 \mathrm{~ns}\right)$ with a low fluorescence quantum yield $\left(\Phi_{\mathrm{F}}=0.008\right)$. However, the bulkier $\boldsymbol{o}$-OPhos exhibits a dramatic increase in fluorescence quantum yield $\left(\Phi_{\mathrm{F}}=0.62\right)$ and excited-state lifetime $\left(\tau_{\mathrm{av}} \sim 4.51 \mathrm{~ns}\right)$, which is a typical excited-state lifetime for common BODIPY dyes that are highly emissive in solution (Figure S14). Fluorescence lifetime analysis shows a decreased rate constant for nonradiative deactivation $\left(k_{\mathrm{nr}}\right)$ and an increased rate constant for radiative deactivation $\left(k_{\mathrm{r}}\right)$ of $\boldsymbol{o}$-OPhos $\left(k_{\mathrm{nr}}=8.43 \times 10^{7} ; k_{\mathrm{r}}=1.37 \times 10^{8}\right)$, compared to those of $\boldsymbol{o}-\mathbf{O H}\left(k_{\mathrm{nr}}=5.22 \times 10^{9}\right.$; $\left.k_{\mathrm{r}}=4.21 \times 10^{7}\right)$ in EtOH. The result is consistent with the conversion of probe $\boldsymbol{o}-\mathbf{O H}$ upon reaction with DCP to the bulkier $\boldsymbol{o}$-OPhos, resulting in a significant fluorescence turn-on signal.

In contrast, the data for the two control compounds $\boldsymbol{p}-\mathbf{O H}$ and $\boldsymbol{p}$-OPhos, which allow free intramolecular rotation of the aryl group, are similar to that of $\boldsymbol{o}-\mathbf{O H}$ : low fluorescence quantum yields $\left(\boldsymbol{p}-\mathbf{O H}: \Phi_{\mathrm{F}}=0.029\right.$; p-OPhos: $\left.\Phi_{\mathrm{F}}=0.027\right)$ and short excited-state lifetimes $\left(\boldsymbol{p}\right.$-OH: $\tau_{\mathrm{av}}=0.32 \mathrm{~ns} ; \boldsymbol{p}$-OPhos: $\left.\tau_{\mathrm{av}}=0.26 \mathrm{~ns}\right)$ in EtOH (Figure S18). Fluorescence lifetime analysis shows that $\boldsymbol{p}-\mathbf{O H}$ and $\boldsymbol{p}$-OPhos have large rate constants for nonradiative deactivation $\left(k_{\mathrm{nr}}\right)\left(\boldsymbol{p}-\mathbf{O H} k_{\mathrm{nr}}=3.03 \times 10^{9} ; \boldsymbol{p}\right.$-OPhos $\left.k_{\mathrm{nr}}=3.74 \times 10^{9}\right)$ and small rate constants for radiative deactivation $\left(k_{\mathrm{r}}\right)\left(\boldsymbol{p}\right.$-OH $k_{\mathrm{r}}=9.06 \times 10^{7} ; \boldsymbol{p}$-OPhos $\left.k_{\mathrm{r}}=1.04 \times 10^{8}\right)$ in EtOH. 


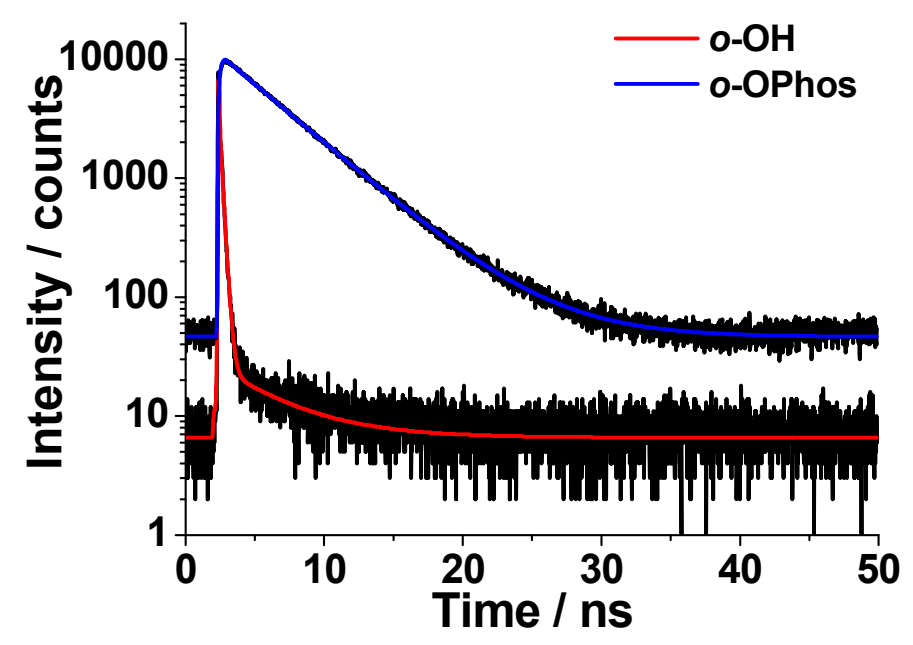

Figure S13. Time-resolved emission decays of $\boldsymbol{o}-\mathbf{O H}$ (red) and $\boldsymbol{o}$-OPhos (blue) in DMF. (red) $\boldsymbol{o}-\mathbf{O H}$ triexponential decays gave lifetimes of $0.044 \mathrm{~ns}(65.85 \%), 0.209 \mathrm{~ns}(34 \%)$ and $4.534 \mathrm{~ns}(0.15 \%)$. Average lifetime of 0.11 ns. (blue) $\boldsymbol{o}$-OPhos monoexponential decays gave lifetimes of $4.39 \mathrm{~ns}(100 \%)$.

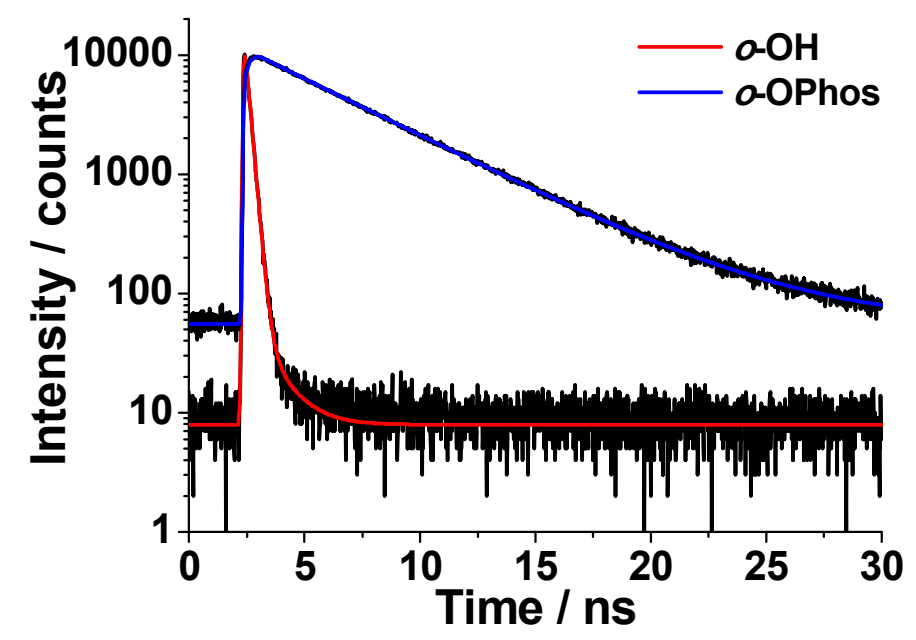

Figure S14. Time-resolved emission decays of $\boldsymbol{o}-\mathbf{O H}$ (red) and $\boldsymbol{o}$-OPhos (blue) in EtOH. (red) $\boldsymbol{o}-\mathbf{O H}$ biexponential decays gave lifetimes of $0.187 \mathrm{~ns}(99.58 \%)$ and $1.023 \mathrm{~ns}(0.42 \%)$. Average lifetime of $0.19 \mathrm{~ns}$. (blue) $\boldsymbol{o}$-OPhos monoexponential decays gave lifetimes of $4.51 \mathrm{~ns}(100 \%)$. 


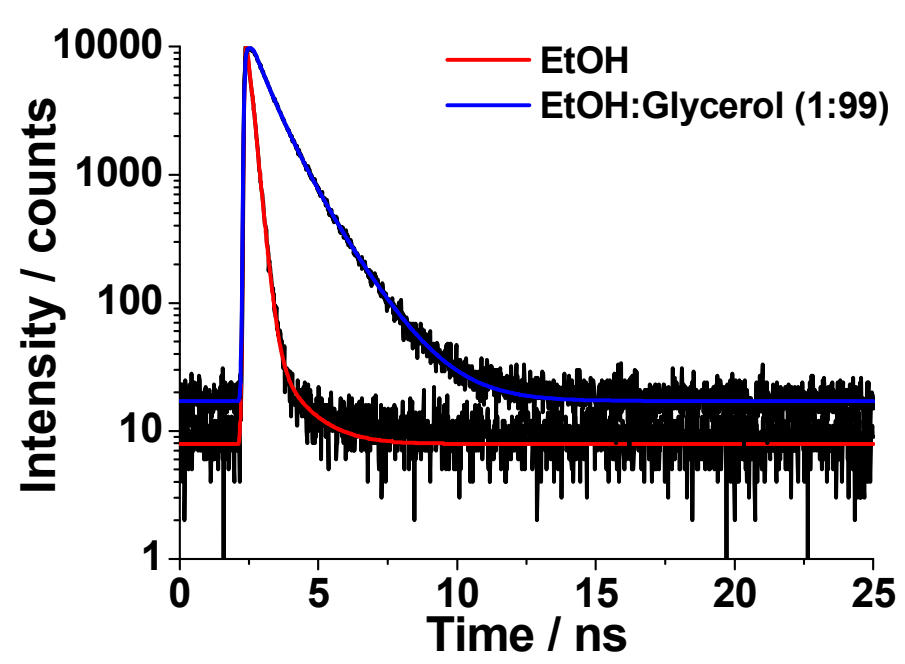

Figure S15. Time-resolved emission decays of $\boldsymbol{o}-\mathbf{O H}$ in EtOH (red) and in ethanol-glycerol (1:99, v/v) (blue). (red) Time-resolved emission decays of $\boldsymbol{o}-\mathbf{O H}$ in EtOH. $\boldsymbol{o}-\mathbf{O H}$ biexponential decays gave lifetimes of $0.187 \mathrm{~ns}$ $(99.58 \%)$ and $1.023 \mathrm{~ns}(0.42 \%)$. Average lifetime of $0.19 \mathrm{~ns}$. (blue) Time-resolved emission decays of $\boldsymbol{o}$-OH in ethanol-glycerol $(1: 99, \mathrm{v} / \mathrm{v}) . \boldsymbol{o}$-OH biexponential decays gave lifetimes of $1.285 \mathrm{~ns}(34.28 \%)$ and $0.62 \mathrm{~ns}$ $(65.72 \%)$. Average lifetime of $0.85 \mathrm{~ns}$.

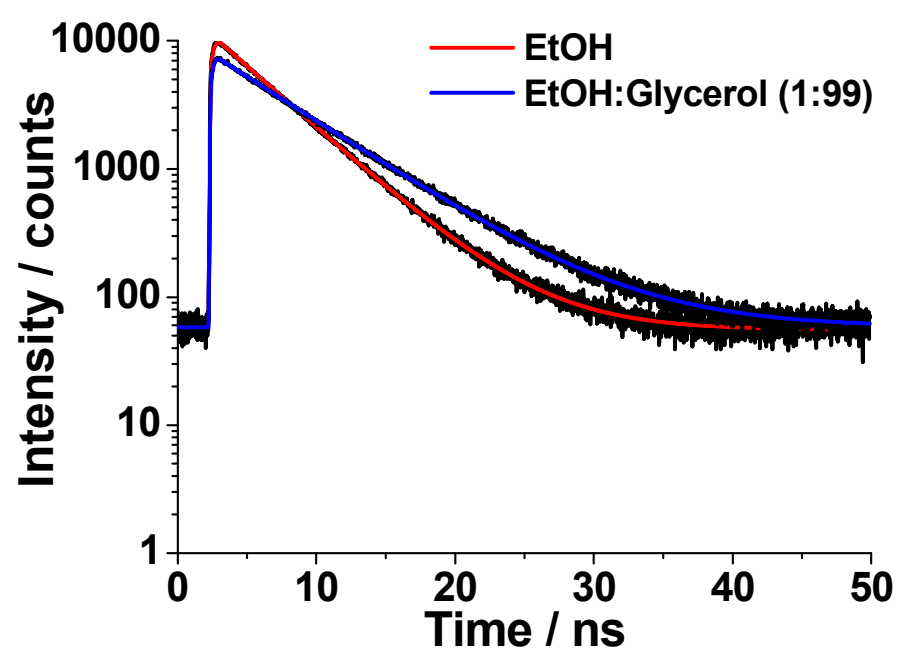

Figure S16. Time-resolved emission decays of $\boldsymbol{o}$-OPhos in EtOH (red) and in ethanol-glycerol $(1: 99, \mathrm{v} / \mathrm{v})$ (blue). (red) Time-resolved emission decays of $\boldsymbol{o}$-OPhos in EtOH. $\boldsymbol{o}$-OPhos monoexponential decays gave lifetimes of $4.51 \mathrm{~ns}(100 \%)$. (blue) Time-resolved emission decays of $\boldsymbol{o}$-OPhos in ethanol-glycerol $(1: 99, \mathrm{v} / \mathrm{v})$. $\boldsymbol{o}$-OPhos monoexponential decays gave lifetimes of $6.2 \mathrm{~ns}(100 \%)$. 


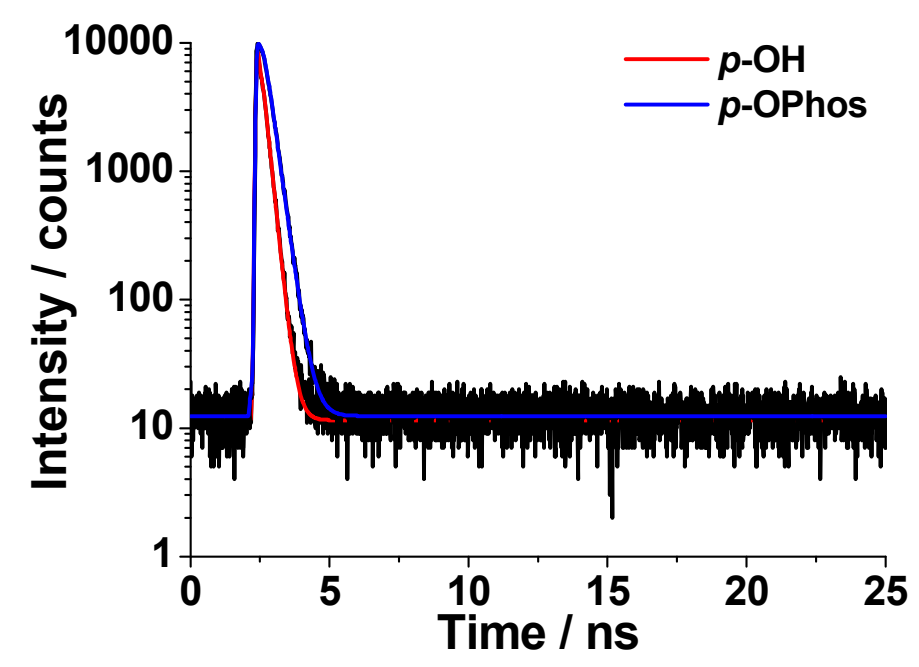

Figure S17. Time-resolved emission decays of $\boldsymbol{p}$-OH (red) and $\boldsymbol{p}$-OPhos (blue) in DMF. (red) $\boldsymbol{p}$-OH monoexponential decays gave lifetimes of 0.2 ns $(100 \%)$. (blue) p-OPhos monoexponential decays gave lifetimes of $0.27 \mathrm{~ns}(100 \%)$.

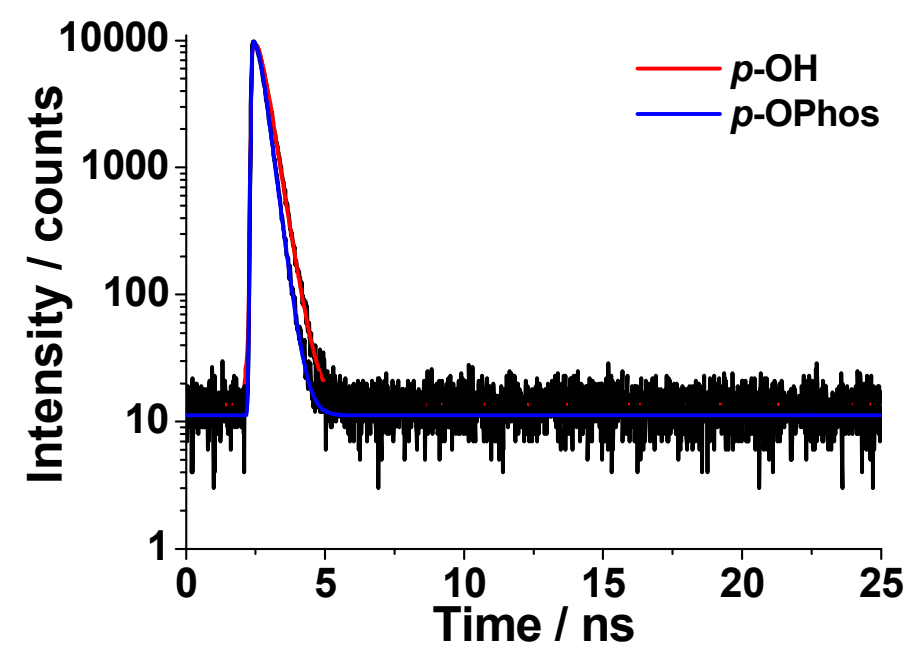

Figure S18. Time-resolved emission decays of $\boldsymbol{p}$-OH (red) and $\boldsymbol{p}$-OPhos (blue) in EtOH. (red) $\boldsymbol{p}$-OH monoexponential decays gave lifetimes of $0.32 \mathrm{~ns}(100 \%)$. (blue) $\boldsymbol{p}$-OPhos monoexponential decays gave lifetimes of $0.26 \mathrm{~ns}(100 \%)$. 


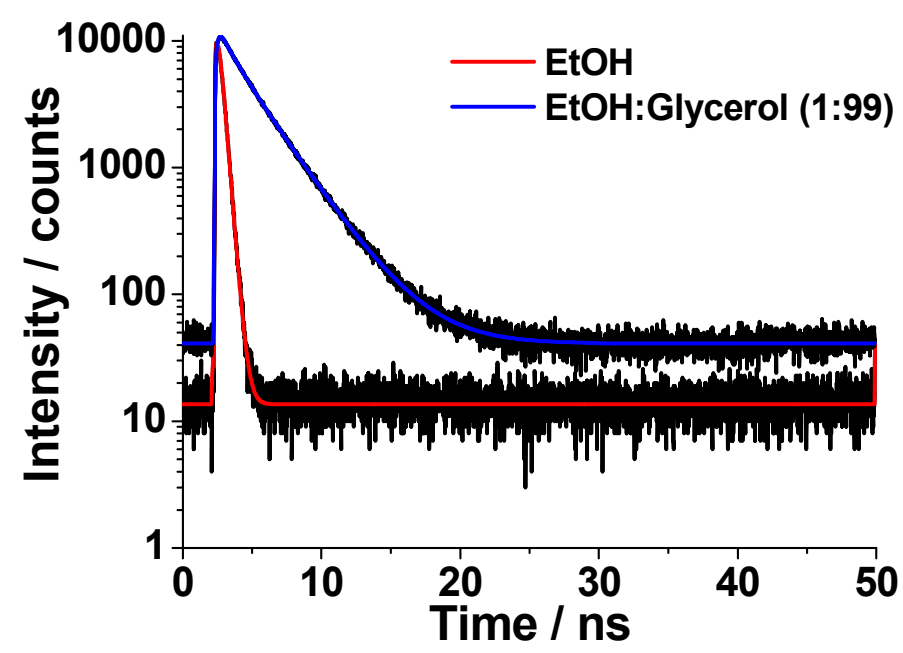

Figure S19. Time-resolved emission decays of $\boldsymbol{p}$-OH in EtOH (red) and in ethanol-glycerol (1:99, v/v) (blue). (red) Time-resolved emission decays of $\boldsymbol{p}-\mathbf{O H}$ in EtOH. $\boldsymbol{p}$ - $\mathbf{O H}$ monoexponential decays gave lifetimes of 0.32 ns $(100 \%)$. (blue) Time-resolved emission decays of $\boldsymbol{p}$ - $\mathbf{O H}$ in ethanol-glycerol $(1: 99, \mathrm{v} / \mathrm{v})$. $\boldsymbol{p}$-OH biexponential decays gave lifetimes of $1.166 \mathrm{~ns}(24.09 \%)$ and $2.751 \mathrm{~ns}(75.91 \%)$. Average lifetime of $2.37 \mathrm{~ns}$.

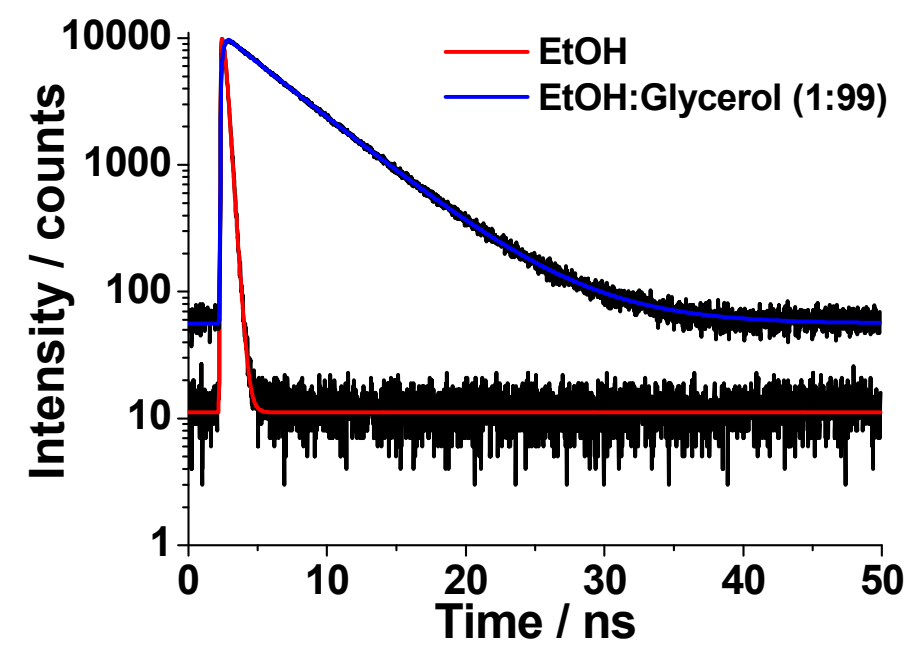

Figure S20. Time-resolved emission decays of $\boldsymbol{p}$-OPhos in EtOH (red) and in ethanol-glycerol $(1: 99, \mathrm{v} / \mathrm{v})$ (blue). (red) Time-resolved emission decays of $\boldsymbol{p}$-OPhos in EtOH. $\boldsymbol{p}$-OPhos monoexponential decays gave lifetimes of $0.26 \mathrm{~ns}(100 \%)$. (blue) Time-resolved emission decays of $\boldsymbol{p}$-OPhos in ethanol-glycerol (1:99, v/v). p-OPhos monoexponential decays gave lifetimes of $4.98 \mathrm{~ns}(100 \%)$. 


\section{Stability Studies}

The chemical stability of $\boldsymbol{o}-\mathbf{O H}$ and $\boldsymbol{o}-\mathbf{O H} / \mathrm{TEA} / \mathrm{DMAP}$ system was examined in DMF at $25^{\circ} \mathrm{C}$. As shown in Figure S21-22, Negligible change in the fluorescence spectra of both $\boldsymbol{o}-\mathbf{O H}$ and $\boldsymbol{o}-\mathbf{O H} / \mathrm{TEA} / \mathrm{DMAP}$ system was detected following incubation for $120 \mathrm{~min}$ in DMF at $25^{\circ} \mathrm{C}$, indicating excellent stability of $\boldsymbol{o}-\mathbf{O H}$ in assay solution. We also investigated photostabilities of $\boldsymbol{o}-\mathbf{O H}$ and $\boldsymbol{o - O H} / \mathrm{TEA} / \mathrm{DMAP}$ system in DMF at $25{ }^{\circ} \mathrm{C}$ (Figure S23). The photooxidation studies were performed by continuous UV irradiation of each solution using a $150 \mathrm{~W}$ steady-state Xe lamp as the irradiation source under aerobic conditions. The photoinduced degradation was quantified by monitoring the decrease of fluorescence intensity of $\boldsymbol{o}-\mathbf{O H}$ as a function of elapsed photolysis time.

(a) Chemical stability studies of o-OH and o-OH/TEA/DMAP system

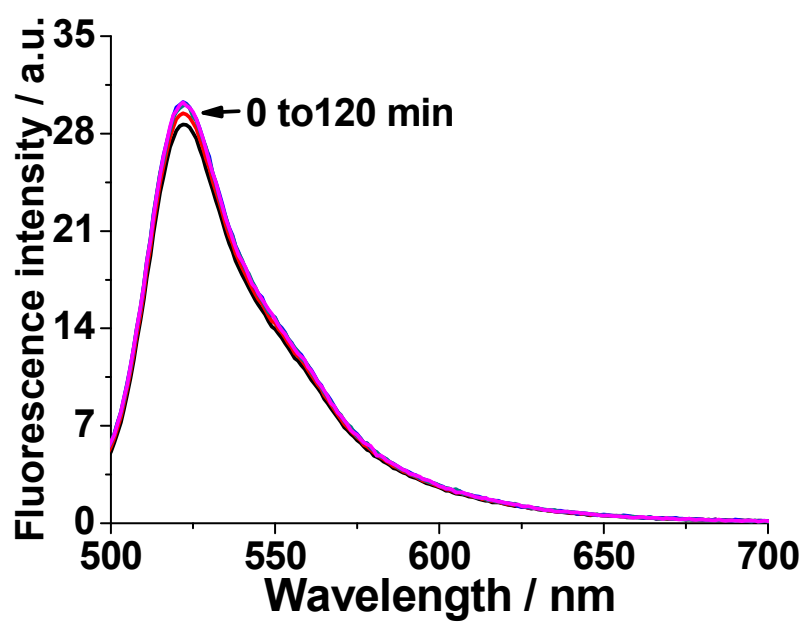

Figure S21. Time-dependent fluorescence emission spectra of $\boldsymbol{o - O H}$ in DMF at $25{ }^{\circ} \mathrm{C}$. The spectra were obtained every $30 \mathrm{~min}(0-120 \mathrm{~min})$. Excited at $480 \mathrm{~nm} .[\boldsymbol{o}-\mathbf{O H}]=10 \mu \mathrm{M}$.

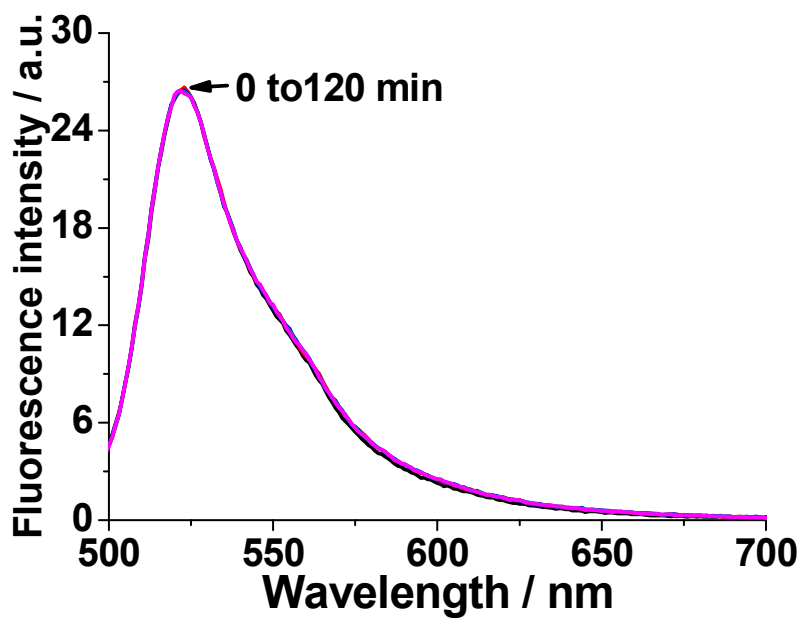

Figure S22. Fluorescence emission spectra of $\boldsymbol{o - O H} / \mathrm{TEA} / \mathrm{DMAP}$ system in DMF at $25{ }^{\circ} \mathrm{C}$. The spectra were obtained every $30 \mathrm{~min}(0-120 \mathrm{~min})$. Excited at $480 \mathrm{~nm}$. $[\boldsymbol{o}-\mathbf{O H}]=10 \mu \mathrm{M}$. [TEA] $=20 \mu \mathrm{M}$. [DMAP] $=10 \mu \mathrm{M}$. 


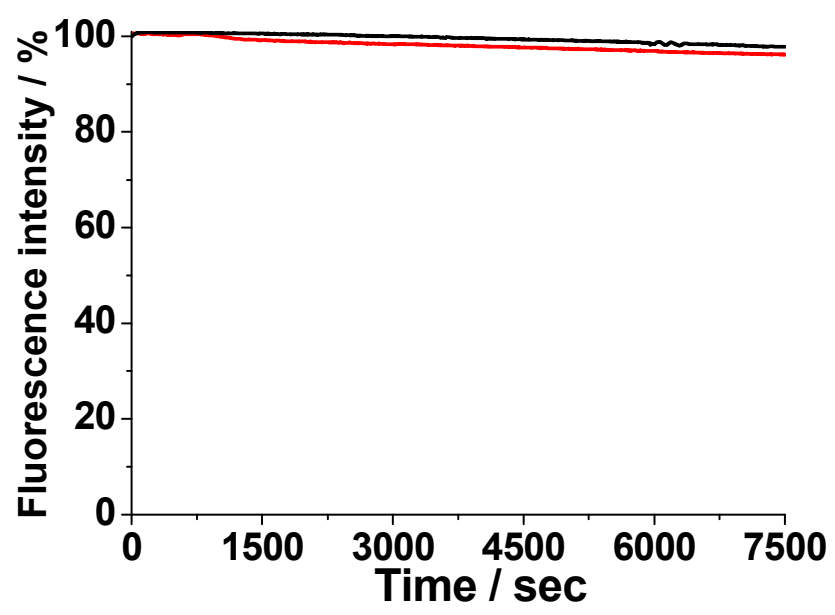

Figure S23. Photostability of $\boldsymbol{o}-\mathbf{O H}$ and $\boldsymbol{o}-\mathbf{O H} / \mathrm{TEA} / \mathrm{DMAP}$ system in DMF. The remaining fluorescence emission intensities of $\boldsymbol{o}-\mathbf{O H}$ (black) and $\boldsymbol{o}-\mathbf{O H} / \mathrm{TEA} / \mathrm{DMAP}$ system (red) as a function of irradiation time. Irradiated at $480 \mathrm{~nm}$. Fluorescence intensity was measured at $523 \mathrm{~nm}$. $[\boldsymbol{o}-\mathbf{O H}]=10 \mu \mathrm{M}$. [TEA] $=20 \mu \mathrm{M}$. $[\mathrm{DMAP}]=10 \mu \mathrm{M}$. 


\section{DFT Calculations}

Geometric optimizations and energy level calculations were performed in the gas phase at the B3LYP 6$311++\mathrm{G}(\mathrm{d}, \mathrm{p})$ level of theory, using the Gaussian 09 software package. ${ }^{7}$ Absolute energies in Hartrees are given without additional corrections.

For each fluorophore were obtained the energy levels of the HOMO of the meso arene substituent, that of the boron dipyrromethene core, and the energy difference $(\Delta)$ between the two. This energy difference was plotted against the reported fluorescence QY of literature dyes (Figure 4 of the manuscript). Whenever possible, reported QY in acetonitrile solvent were selected for the purposes of comparison. Otherwise, QY reported in a solvent of close polarity was privileged when available.

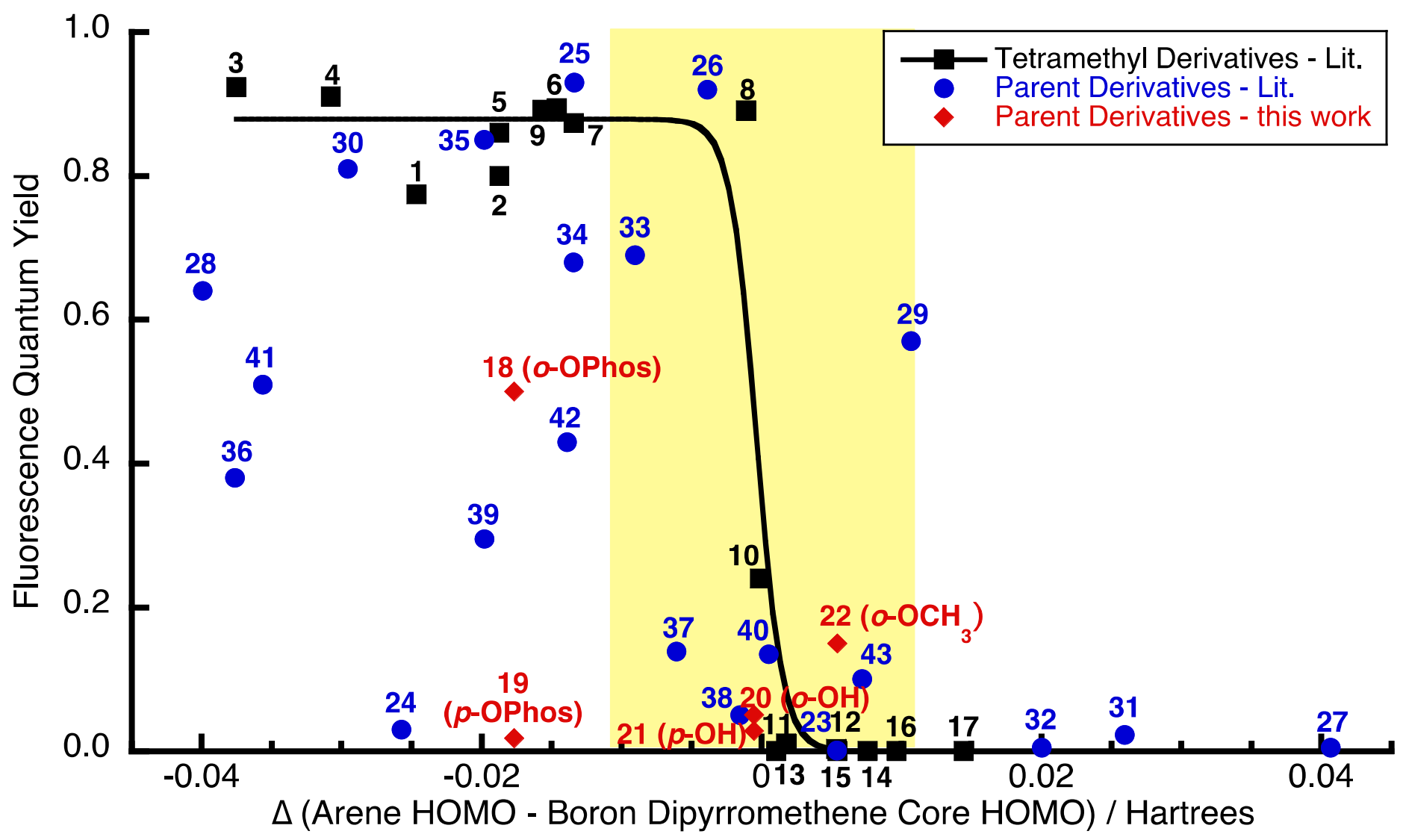

The black line on the above graph represents the best numerical fitting of the literature data for 1,3,5,7tetramethylBODIPY derivatives to a modified Marcus equation $\left(\Phi_{\mathrm{Max}}=0.879 ; a=4.11 \times 10^{-6} ; \Delta_{0}=-0.0119\right)$ :

$$
\Phi_{F}=\Phi_{M a x}\left(\frac{1}{1+k_{P e T}}\right)
$$

where:

$$
\begin{aligned}
& k_{P e T}=a \cdot e^{\left(\frac{\Delta-\Delta_{0}}{k_{B} T}\right)} \\
& k_{B}=3.167 \times 10^{-6} \text { Hartree } \cdot \mathrm{K}^{-1} \text { (Boltzmann constant) } \\
& T=295 \mathrm{~K}
\end{aligned}
$$




\begin{tabular}{|c|c|c|c|c|c|}
\hline Fluorophore & $\begin{array}{l}\text { Boron } \\
\text { Dipyrromethene } \\
\text { Core Energy } \\
\text { Levels }\end{array}$ & $\begin{array}{l}\text { Meso Arene } \\
\text { Substituent } \\
\text { Energy Levels }\end{array}$ & $\begin{array}{c}\Delta \\
\text { (Arene } \\
\text { HOMO - } \\
\text { Core } \\
\text { HOMO) }\end{array}$ & $\begin{array}{c}\Phi_{\mathrm{F}} \\
\text { (solvent) }\end{array}$ & Literature Reference \\
\hline \multicolumn{6}{|c|}{ 1. 1,3,5,7-TetramethyIBODIPY Derivatives } \\
\hline 1 & 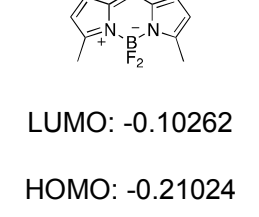 & $\begin{array}{l}\text { LUMO: }-0.02097 \\
\text { HOMO: }-0.23488\end{array}$ & -0.02464 & $\begin{array}{c}0.774 \\
(\mathrm{MeCN})\end{array}$ & $\begin{array}{c}\text { Kobayashi, T.; Komatsu, T.; Kamiya, M.; Campos, C.; } \\
\text { González-Gaitán, M.; Terai, T.; Hanaoka, K.; Nagano, } \\
\text { T.; Urano, Y. J. Am. Chem. Soc. 2012, 134, 11153- } \\
11160 .\end{array}$ \\
\hline 2 & $\begin{array}{l}\text { LUMO: }-0.10262 \\
\text { HOMO: }-0.21024\end{array}$ & $\begin{array}{l}\text { LUMO: }-0.01692 \\
\text { HOMO: }-0.22894\end{array}$ & -0.01870 & $\begin{array}{c}0.80 \\
\left(\mathrm{CH}_{2} \mathrm{Cl}_{2}\right)\end{array}$ & $\begin{array}{l}\text { (a) Zhu, S.; Zhang, J.; Vegesna, G.; Tiwari, A.; Luo, F.- } \\
\text { T.; Zeller, M.; Luck, R.; Li, H.; Green, S.; Liu, H. RSC } \\
\text { Advances 2012, 2, 404-407. } \\
\text { (b) Donuru, V. R.; Zhu, S.; Green, S.; Liu, H. Polymer } \\
\text { 2010, 51, 5359-5368. } \\
\text { (c) Meng, G.; Velayudham, S.; Smith, A.; Luck, R.; Liu, } \\
\text { H. Macromolecules, 2009, 42, 1995-2001. }\end{array}$ \\
\hline 3 & $\begin{array}{l}\text { LUMO: }-0.10262 \\
\text { HOMO: }-0.21024\end{array}$ & $\begin{array}{l}\text { LUMO: }-0.01594 \\
\text { HOMO: }-0.24773\end{array}$ & -0.03749 & $\begin{array}{c}0.923 \\
(\mathrm{MeCN})\end{array}$ & $\begin{array}{c}\text { Sunahara, H.; Urano, Y.; Kojima, H.; Nagano, T. J. Am. } \\
\text { Chem. Soc. 2007, 129, 5597-5604 }\end{array}$ \\
\hline 4 & $\begin{array}{l}\text { LUMO: }-0.10262 \\
\text { HOMO: }-0.21024\end{array}$ & $\begin{array}{l}\text { LUMO: }-0.01456 \\
\text { HOMO: }-0.24098\end{array}$ & -0.03074 & $\begin{array}{c}0.910 \\
(\mathrm{MeCN})\end{array}$ & $\begin{array}{c}\text { Sunahara, H.; Urano, Y.; Kojima, H.; Nagano, T. J. Am. } \\
\text { Chem. Soc. 2007, 129, 5597-5604 }\end{array}$ \\
\hline 5 & $\begin{array}{l}\text { LUMO: }-0.10262 \\
\text { HOMO: }-0.21024\end{array}$ & $\begin{array}{l}\text { LUMO: }-0.01692 \\
\text { HOMO: }-0.22894\end{array}$ & -0.01870 & $\begin{array}{l}0.860 \\
(\mathrm{MeCN})\end{array}$ & $\begin{array}{c}\text { Sunahara, H.; Urano, Y.; Kojima, H.; Nagano, T. J. Am. } \\
\text { Chem. Soc. 2007, 129, 5597-5604 }\end{array}$ \\
\hline 6 & $\begin{array}{l}\text { LUMO: }-0.10262 \\
\text { HOMO: }-0.21024\end{array}$ & $\begin{array}{l}\text { LUMO: }-0.05136 \\
\text { HOMO: }-0.22585\end{array}$ & -0.01561 & $\begin{array}{c}0.892 \\
(\mathrm{MeCN})\end{array}$ & $\begin{array}{c}\text { Sunahara, H.; Urano, Y.; Kojima, H.; Nagano, T. J. Am. } \\
\text { Chem. Soc. 2007, 129, 5597-5604 }\end{array}$ \\
\hline 7 & $\begin{array}{l}\text { LUMO: }-0.10262 \\
\text { HOMO: }-0.21024\end{array}$ & LUMO: -0.01116 & -0.01338 & $\begin{array}{c}0.873 \\
(\mathrm{MeCN})\end{array}$ & $\begin{array}{c}\text { Sunahara, H.; Urano, Y.; Kojima, H.; Nagano, T. J. Am. } \\
\text { Chem. Soc. 2007, 129, 5597-5604 }\end{array}$ \\
\hline
\end{tabular}




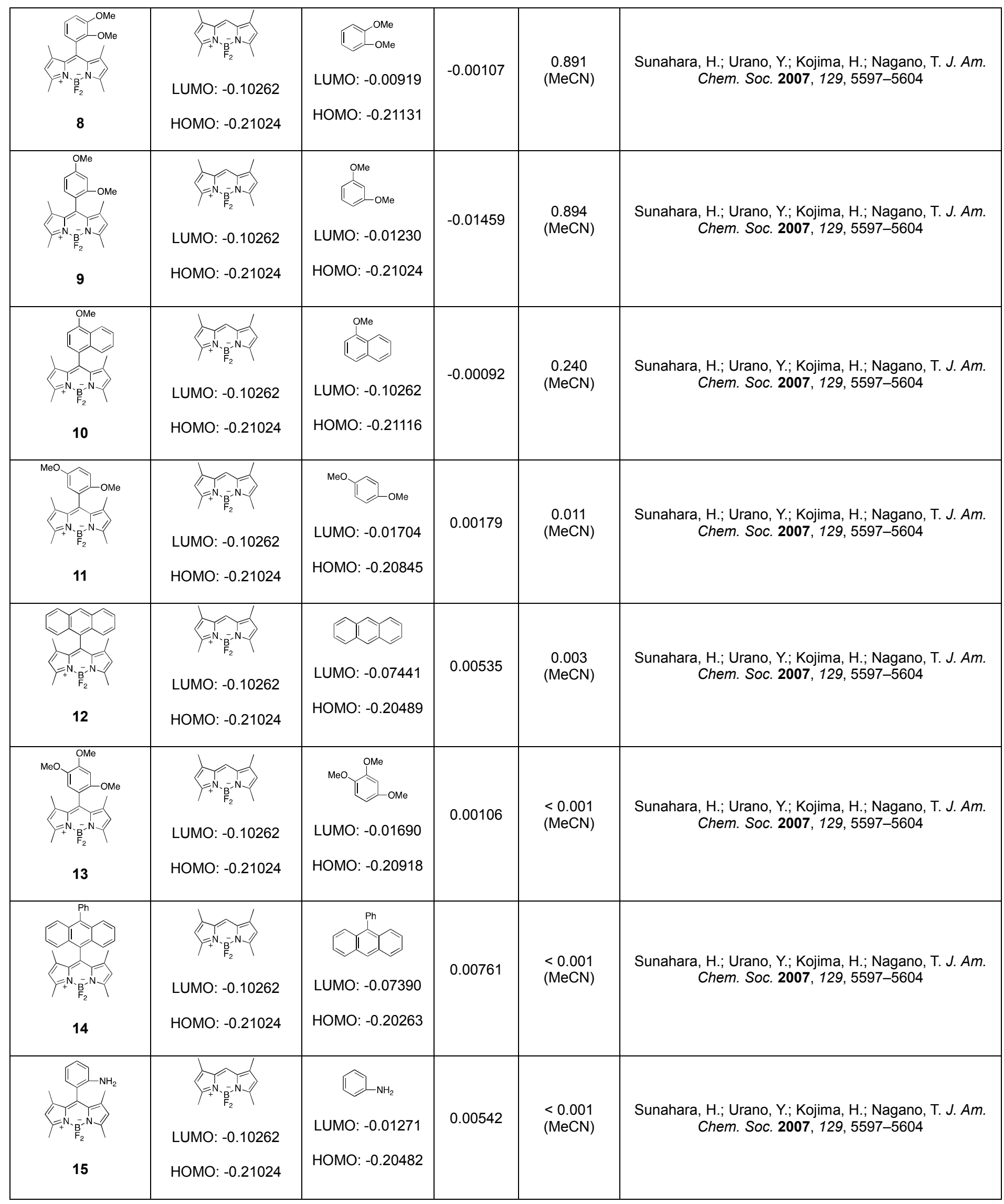




\begin{tabular}{|c|c|c|c|c|c|}
\hline (1) & $\begin{array}{l}\text { LUMO: }-0.10262 \\
\text { HOMO: }-0.21024\end{array}$ & $\begin{array}{l}\text { LUMO: }-0.07343 \\
\text { HOMO: }-0.20058\end{array}$ & 0.00966 & $\begin{array}{l}<0.001 \\
(\mathrm{MeCN})\end{array}$ & $\begin{array}{c}\text { Sunahara, H.; Urano, Y.; Kojima, H.; Nagano, T. J. Am. } \\
\text { Chem. Soc. 2007, 129, 5597-5604 }\end{array}$ \\
\hline 17 & $\begin{array}{l}\text { LUMO: }-0.10262 \\
\text { HOMO: }-0.21024\end{array}$ & $\begin{array}{l}\text { LUMO: }-0.01505 \\
\text { HOMO: }-0.19576\end{array}$ & 0.01448 & $\begin{array}{l}<0.001 \\
(\mathrm{MeCN})\end{array}$ & $\begin{array}{c}\text { Sunahara, H.; Urano, Y.; Kojima, H.; Nagano, T. J. Am. } \\
\text { Chem. Soc. 2007, 129, 5597-5604 }\end{array}$ \\
\hline \multicolumn{6}{|c|}{ 2a. Parent BODIPY Derivatives - This Work } \\
\hline 18 & $\begin{array}{l}\text { LUMO: }-0.12111 \\
\text { HOMO: }-0.23438\end{array}$ & $\begin{array}{l}\text { LUMO: }-0.02550 \\
\text { HOMO: }-0.25204\end{array}$ & -0.01766 & $\begin{array}{c}0.50 \\
(\mathrm{MeCN})\end{array}$ & this work \\
\hline 19 & $\begin{array}{l}\text { LUMO: }-0.12111 \\
\text { HOMO: }-0.23438\end{array}$ & $\begin{array}{l}\text { LUMO: }-0.02550 \\
\text { HOMO: }-0.25204\end{array}$ & -0.01766 & $\begin{array}{c}0.018 \\
(\mathrm{MeCN})\end{array}$ & this work \\
\hline 20 & $\begin{array}{l}\text { LUMO: }-0.12111 \\
\text { HOMO: }-0.23438\end{array}$ & $\begin{array}{l}\text { LUMO: }-0.02097 \\
\text { HOMO: }-0.23488\end{array}$ & -0.00050 & $\begin{array}{c}0.050 \\
(\mathrm{MeCN})\end{array}$ & this work \\
\hline 21 & $\begin{array}{l}\text { LUMO: }-0.12111 \\
\text { HOMO: }-0.23438\end{array}$ & $\begin{array}{l}\text { LUMO: }-0.02097 \\
\text { HOMO: }-0.23488\end{array}$ & -0.00050 & $\begin{array}{c}0.028 \\
(\mathrm{MeCN})\end{array}$ & this work \\
\hline 22 & $\begin{array}{l}\text { LUMO: }-0.12111 \\
\text { HOMO: }-0.23438\end{array}$ & $\begin{array}{l}\text { LUMO: }-0.01692 \\
\text { HOMO: }-0.22894\end{array}$ & 0.00544 & $\begin{array}{c}0.15 \\
(\mathrm{MeCN})\end{array}$ & this work \\
\hline \multicolumn{6}{|c|}{ 2b. Parent BODIPY Derivatives - Literature Data } \\
\hline${ }^{N} \mathrm{~B}_{2}$ & $\begin{array}{c}\text { LUMO: }-0.12111 \\
\text { HOMO: }-0.23438\end{array}$ & LUMO: -0.01692 & 0.00544 & $\begin{array}{c}0.0013 \\
(\mathrm{MeCN})\end{array}$ & $\begin{array}{l}\text { (a) Lakshmi, V.; Ravikanth, M. Chem. Phys. Lett. 2013, } \\
\text { 564, 93-97. } \\
\text { (b) Lakshmi, V.; Ravikanth, M. Dalton Trans. 2012, 41, } \\
\text { 5903-5911. }\end{array}$ \\
\hline
\end{tabular}




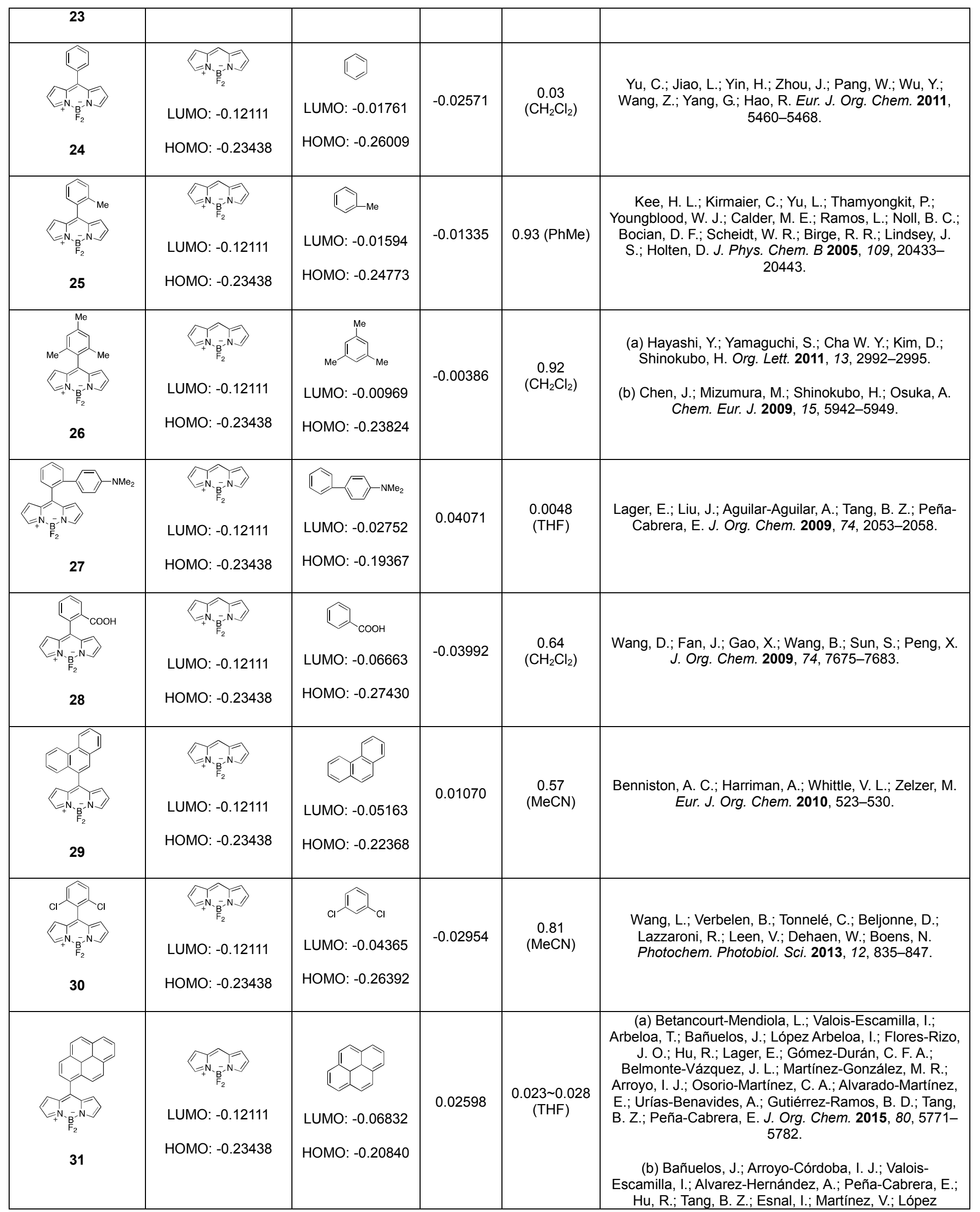




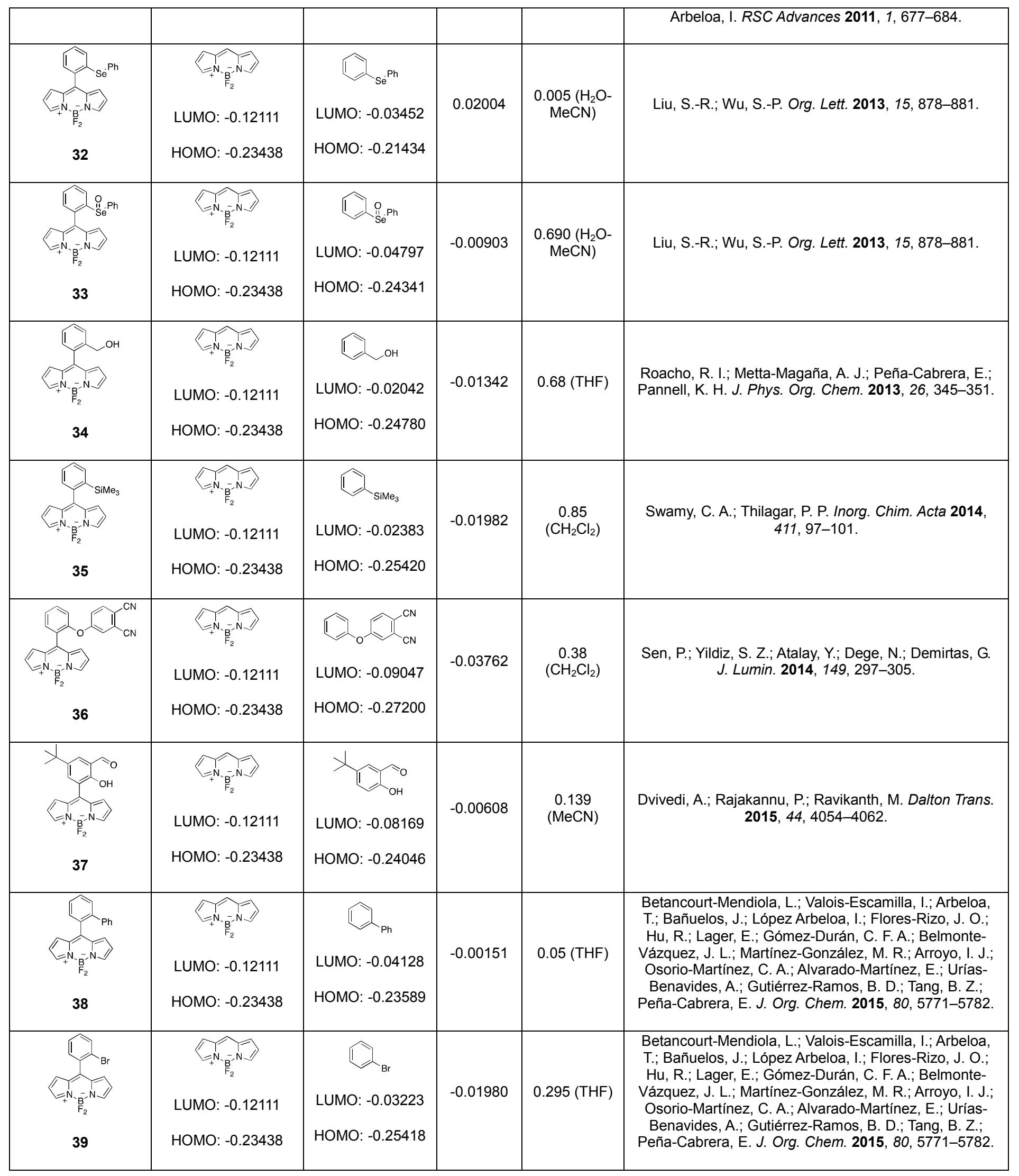




\begin{tabular}{|c|c|c|c|c|c|}
\hline 40 & $\begin{array}{l}\text { LUMO: }-0.12111 \\
\text { HOMO: }-0.23438\end{array}$ & LUMO: -0.05148 & 0.00053 & 0.135 (THF) & $\begin{array}{l}\text { Betancourt-Mendiola, L.; Valois-Escamilla, I.; Arbeloa, } \\
\text { T.; Bañuelos, J.; López Arbeloa, I.; Flores-Rizo, J. O.; } \\
\text { Hu, R.; Lager, E.; Gómez-Durán, C. F. A.; Belmonte- } \\
\text { Vázquez, J. L.; Martínez-González, M. R.; Arroyo, I. J.; } \\
\text { Osorio-Martínez, C. A.; Alvarado-Martínez, E.; Urías- } \\
\text { Benavides, A.; Gutiérrez-Ramos, B. D.; Tang, B. Z.; } \\
\text { Peña-Cabrera, E. J. Org. Chem. 2015, 80, 5771-5782. }\end{array}$ \\
\hline 41 & $\begin{array}{l}\text { LUMO: }-0.12111 \\
\text { HOMO: }-0.23438\end{array}$ & $\begin{array}{l}\text { LUMO: }-0.06016 \\
\text { HOMO: }-0.27001\end{array}$ & -0.03563 & 0.51 (THF) & $\begin{array}{l}\text { Betancourt-Mendiola, L.; Valois-Escamilla, I.; Arbeloa, } \\
\text { T.; Bañuelos, J.; López Arbeloa, I.; Flores-Rizo, J. O.; } \\
\text { Hu, R.; Lager, E.; Gómez-Durán, C. F. A.; Belmonte- } \\
\text { Vázquez, J. L.; Martínez-González, M. R.; Arroyo, I. J.; } \\
\text { Osorio-Martínez, C. A.; Alvarado-Martínez, E.; Urías- } \\
\text { Benavides, A.; Gutiérrez-Ramos, B. D.; Tang, B. Z.; } \\
\text { Peña-Cabrera, E. J. Org. Chem. 2015, 80, 5771-5782. }\end{array}$ \\
\hline 42 & $\begin{array}{l}\text { LUMO: }-0.12111 \\
\text { HOMO: }-0.23438\end{array}$ & $\begin{array}{l}\text { OHC }-0.06764 \\
\text { HOMO: }-0.24827\end{array}$ & -0.01389 & 0.43 (THF) & $\begin{array}{l}\text { Betancourt-Mendiola, L.; Valois-Escamilla, I.; Arbeloa, } \\
\text { T.; Bañuelos, J.; López Arbeloa, I.; Flores-Rizo, J. O.; } \\
\text { Hu, R.; Lager, E.; Gómez-Durán, C. F. A.; Belmonte- } \\
\text { Vázquez, J. L.; Martínez-González, M. R.; Arroyo, I. J.; } \\
\text { Osorio-Martínez, C. A.; Alvarado-Martínez, E.; Urías- } \\
\text { Benavides, A.; Gutiérrez-Ramos, B. D.; Tang, B. Z.; } \\
\text { Peña-Cabrera, E. J. Org. Chem. 2015, 80, 5771-5782. }\end{array}$ \\
\hline 43 & $\begin{array}{l}\text { LUMO: }-0.12111 \\
\text { HOMO: }-0.23438\end{array}$ & $\begin{array}{l}\text { LUMO: }-0.03281 \\
\text { HOMO: }-0.22717\end{array}$ & 0.00721 & $\begin{array}{c}0.10 \\
\left(\mathrm{CH}_{2} \mathrm{Cl}_{2}\right)\end{array}$ & $\begin{array}{l}\text { Papalia, T.; Lappano, R.; Barattucci, A.; Pisano, A.; } \\
\text { Bruno, G.; Santolla, M. F.; Campagna, S.; De Marco, P.; } \\
\text { Puntoriero, F.; De Francesco, E. M.; Rosano, C.; } \\
\text { Maggiolini, M.; Bonaccorsi, P. Org. Biomol. Chem. } \\
\text { 2015, 13, 10437-10441. }\end{array}$ \\
\hline
\end{tabular}




\section{Fluorometric Assay Studies}

Preparation of stock solution and general procedure: A stock solution of o-OH (1 mM in DMF, $20 \mu \mathrm{L})$ was diluted with DMF (1.97 mL). $0.5 \mu \mathrm{L}$ of 4-dimethylaminopyridine (DMAP, $10 \mathrm{mg}$ ) dissolved in $\mathrm{CH}_{3} \mathrm{CN}(2 \mathrm{~mL})$ was used to give a final concentration of $10 \mu \mathrm{M}$ DMAP. Solutions of diethyl chlorophosphate (DCP) dissolved in $\mathrm{CH}_{3} \mathrm{CN}$ were prepared at various concentrations. The $\boldsymbol{o}-\mathbf{O H} / \mathrm{TEA} / \mathrm{DMAP}$ system was prepared by the addition of triethylamine (TEA, $5 \mu \mathrm{L})$ and DMAP solution $(0.5 \mu \mathrm{L})$ to the solution of $\boldsymbol{o}-\mathbf{O H}(1.99 \mathrm{~mL})$. Final concentrations of $\boldsymbol{o}-\mathbf{O H}$, TEA, and DMAP in $\boldsymbol{o}-\mathbf{O H} / \mathrm{TEA} / \mathrm{DMAP}$ system were $10 \mu \mathrm{M}, 20 \mu \mathrm{M}$, and $10 \mu \mathrm{M}$, respectively. Fluorescence response of $\boldsymbol{o}-\mathbf{O H} / \mathrm{TEA} / \mathrm{DMAP}$ system was measured $\left(\lambda_{\mathrm{exc}}=480 \mathrm{~nm}\right)$ upon addition of DCP $(2 \mu \mathrm{L})$.

To find optimized fluorimetric assay conditions, effects of TEA, DMAP, and assay solvents on fluorescence turn-on response were investigated.

(a) Effect of TEA on emission properties of o-OH
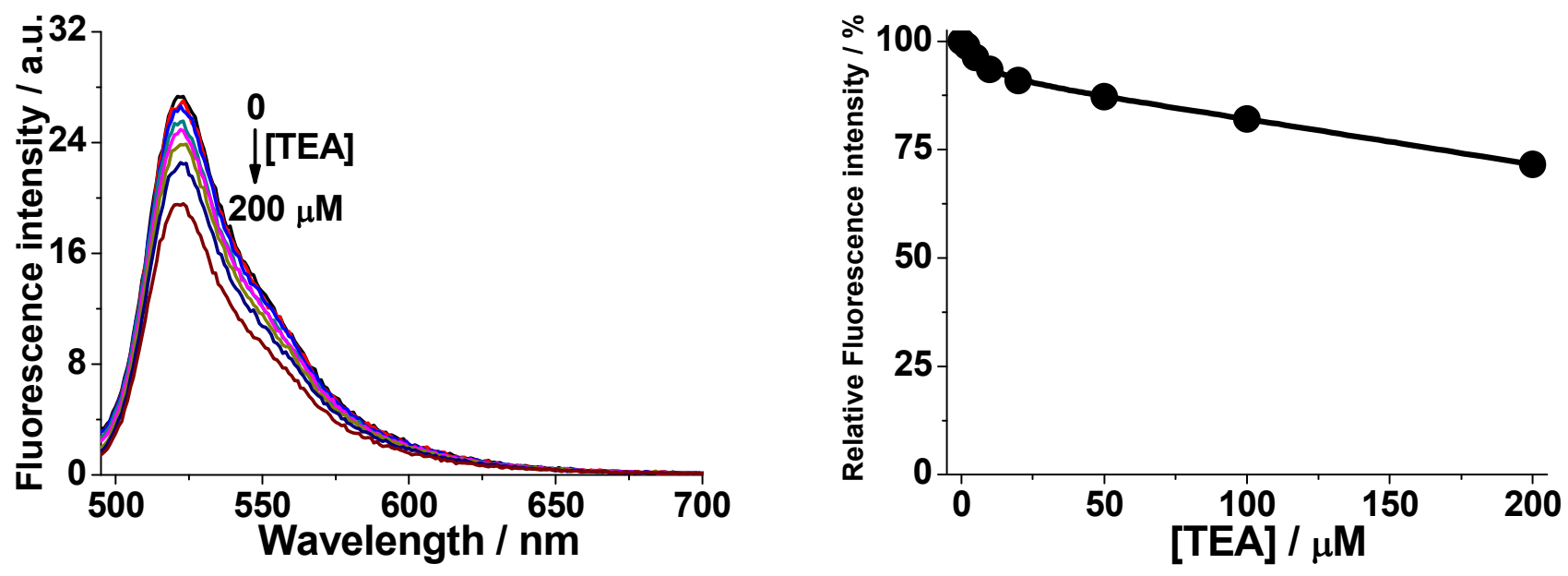

Figure S24. (left) Fluorescence emission spectra of $\boldsymbol{o - O H}(10 \mu \mathrm{M})$ in DMF upon addition of TEA at different concentrations ( 0 to $200 \mu \mathrm{M}$ ). Excited at $480 \mathrm{~nm}$. (right) Relative fluorescence intensity at $523 \mathrm{~nm}$ as a function of concentration of TEA. 

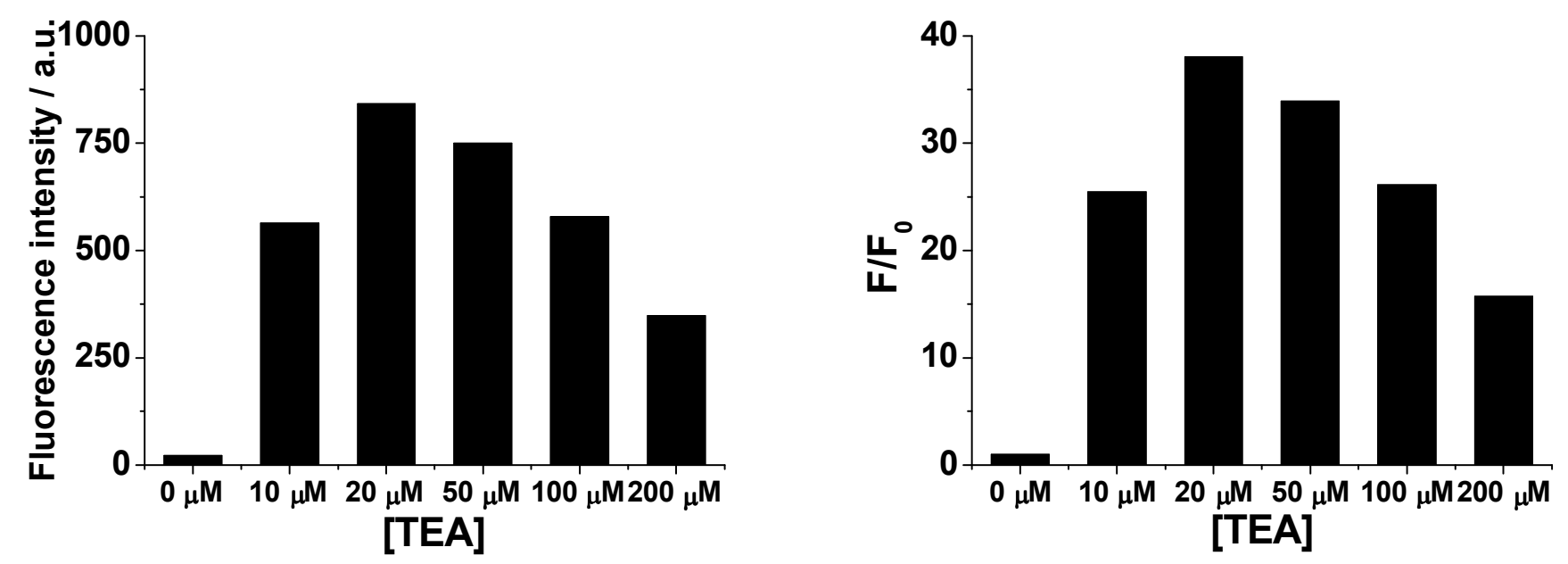

Figure S25. Fluorescence turn-on response of $\boldsymbol{o}-\mathbf{O H}$ upon addition of DCP $(150 \mathrm{mg} / \mathrm{L})$ in DMF containing different amounts of TEA in the absence of DMAP. Excited at $480 \mathrm{~nm}$. All emission spectra were obtained after incubation for $10 \mathrm{~min}$ and fluorescence intensity at $527 \mathrm{~nm}$ were recorded. $[\boldsymbol{o}-\mathbf{O H}]=10 \mu \mathrm{M}$. [TEA] $=$ left to right: $0,10,20,50,100,200 \mu \mathrm{M}$.

(c) Effect of DMAP alone on fluorescence turn-on response of o-OH toward DCP (150 mg/L)
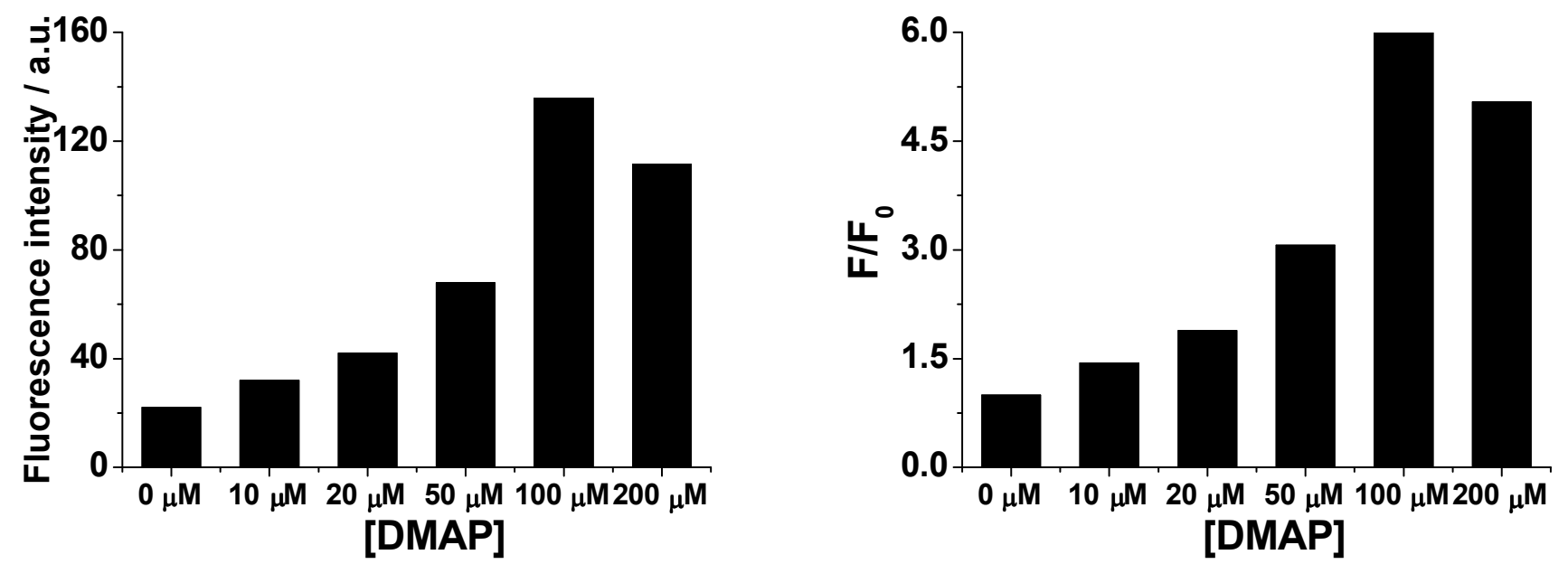

Figure S26. Fluorescence turn-on response of $\boldsymbol{o}-\mathbf{O H}$ upon addition of DCP $(150 \mathrm{mg} / \mathrm{L})$ in DMF containing different amounts of DMAP in the absence of TEA. Excited at $480 \mathrm{~nm}$. All emission spectra were obtained after incubation for $10 \mathrm{~min}$ and fluorescence intensity at $527 \mathrm{~nm}$ were recorded. $[\boldsymbol{o}-\mathbf{O H}]=10 \mu \mathrm{M}$. [DMAP] $=1$ eft to right: $0,10,20,50,100,200 \mu \mathrm{M}$. 
(d) Effect of DMAP in the presence of TEA (2equiv) on fluorescence turn-on response of o-OH toward $\operatorname{DCP}(150 \mathrm{mg} / \mathrm{L})$
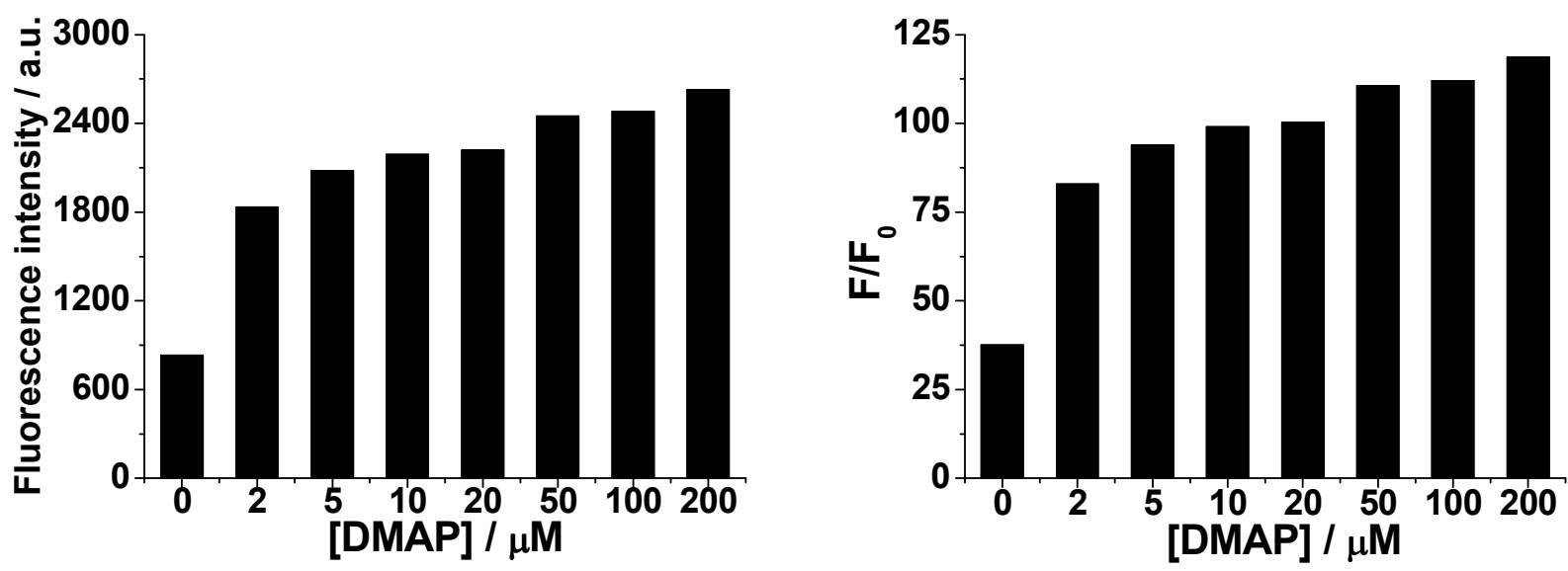

Figure S27. Fluorescence turn-on response of $\boldsymbol{o}-\mathbf{O H}$ upon addition of DCP $(150 \mathrm{mg} / \mathrm{L})$ in DMF containing different amounts of DMAP in the presence of TEA (2 equiv). Excited at $480 \mathrm{~nm}$. All emission spectra were obtained after incubation for $10 \mathrm{~min}$. Fluorescence intensity at $527 \mathrm{~nm}$ was recorded. $[\boldsymbol{o}-\mathbf{O H}]=10 \mu \mathrm{M}$. [TEA] $=$ $20 \mu \mathrm{M}$. [DMAP] $=$ left to right: $0,2,5,10,20,50,100,200 \mu \mathrm{M}$. 
(e) Fluorescence turn-on response of o-OH/TEA/DMAP system toward DCP (150 mg/L) in different solvents
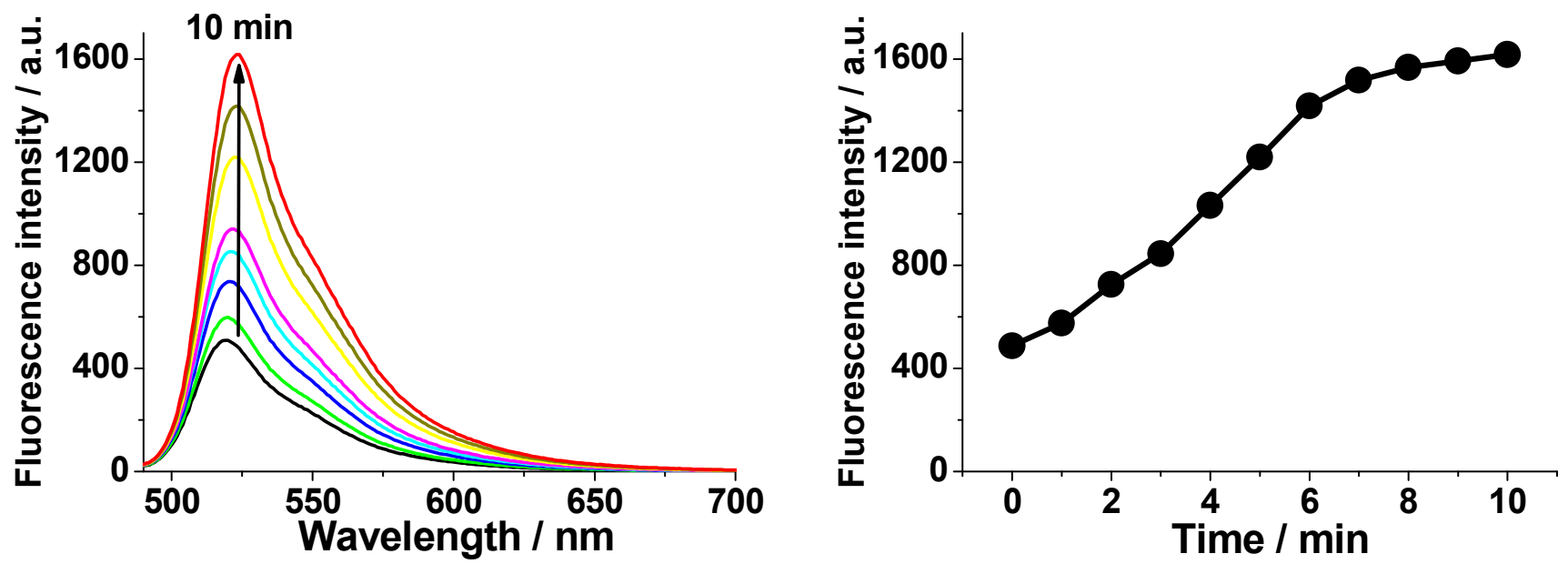

Figure S28. (left) Fluorescence turn-on response of $\boldsymbol{o - O H / T E A / D M A P ~ s y s t e m ~ u p o n ~ a d d i t i o n ~ o f ~ D C P ~ ( 1 5 0 ~}$ $\mathrm{mg} / \mathrm{L})$ in acetone at $25{ }^{\circ} \mathrm{C}$. The spectra were obtained every $1 \mathrm{~min}(0-10 \mathrm{~min})$ after the addition of DCP. Excited at $480 \mathrm{~nm}$. (right) Relative fluorescence intensity at $523 \mathrm{~nm}$ as a function of incubation time. $[\boldsymbol{o}-\mathbf{O H}]=$ $10 \mu \mathrm{M}$. [TEA] $=20 \mu \mathrm{M}$. [DMAP] $=10 \mu \mathrm{M}$.
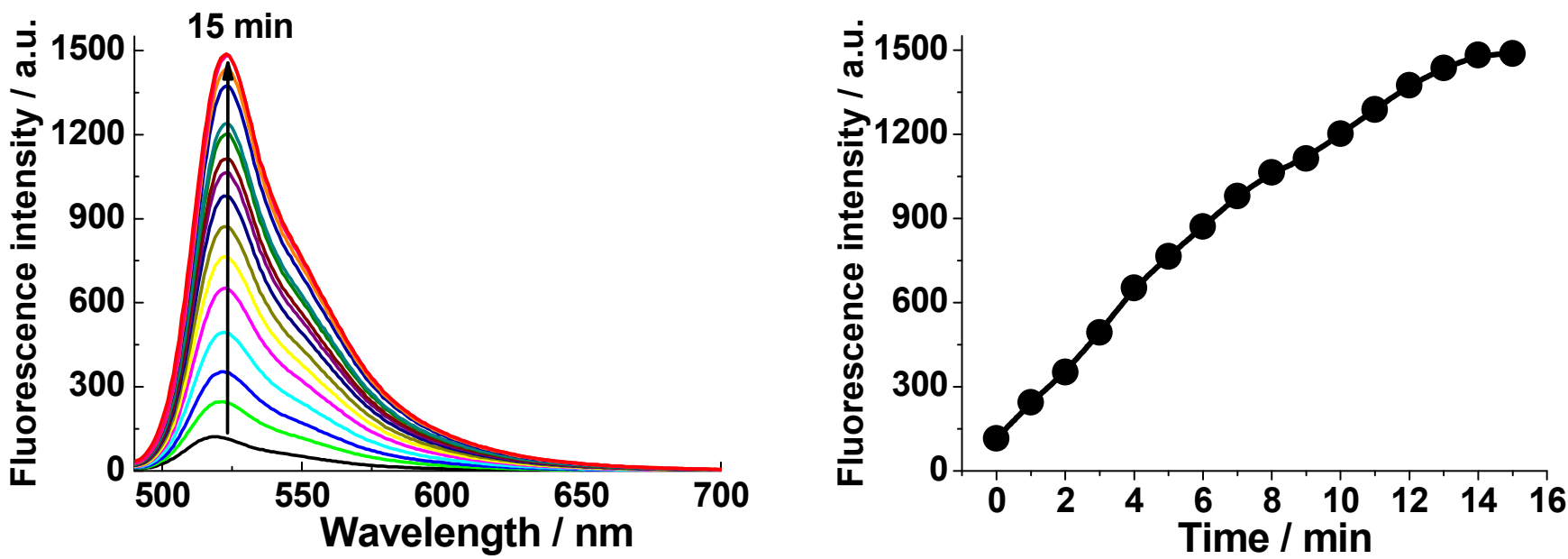

Figure S29. (left) Fluorescence turn-on response of $\boldsymbol{o - O H} / \mathrm{TEA} / \mathrm{DMAP}$ system upon addition of DCP (150 $\mathrm{mg} / \mathrm{L})$ in ethanol at $25^{\circ} \mathrm{C}$. The spectra were obtained every $1 \mathrm{~min}(0-8 \mathrm{~min})$ after the addition of DCP. Excited at $480 \mathrm{~nm}$. (right) Relative fluorescence intensity at $523 \mathrm{~nm}$ as a function of incubation time. $[\boldsymbol{o}-\mathbf{O H}]=10 \mu \mathrm{M}$. $[\mathrm{TEA}]=20 \mu \mathrm{M}$. [DMAP] $=10 \mu \mathrm{M}$. 

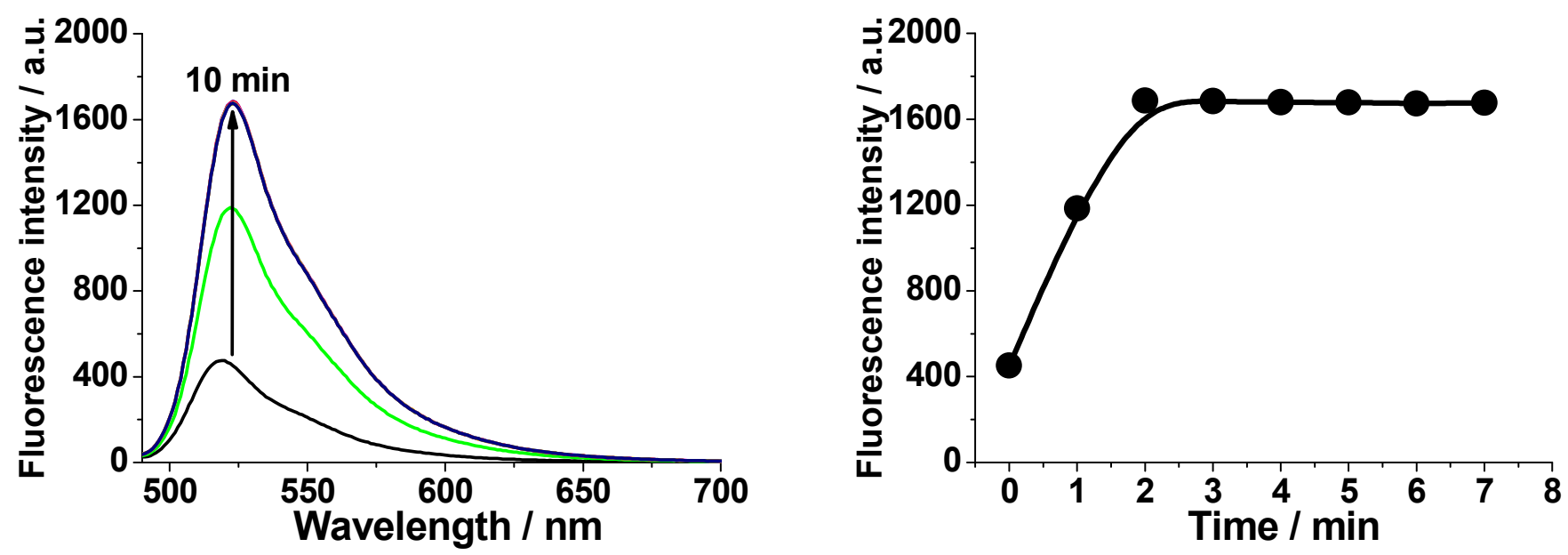

Figure S30. (left) Fluorescence turn-on response of $\boldsymbol{o - O H} / \mathrm{TEA} / \mathrm{DMAP}$ system upon addition of DCP (150 $\mathrm{mg} / \mathrm{L})$ in acetonitrile at $25^{\circ} \mathrm{C}$. The spectra were obtained every $1 \mathrm{~min}(0-8 \mathrm{~min})$ after the addition of DCP. Excited at $480 \mathrm{~nm}$. (right) Relative fluorescence intensity at $523 \mathrm{~nm}$ as a function of incubation time. $[\boldsymbol{o}-\mathbf{O H}]=$ $10 \mu \mathrm{M} .[\mathrm{TEA}]=20 \mu \mathrm{M}$. [DMAP] $=10 \mu \mathrm{M}$.
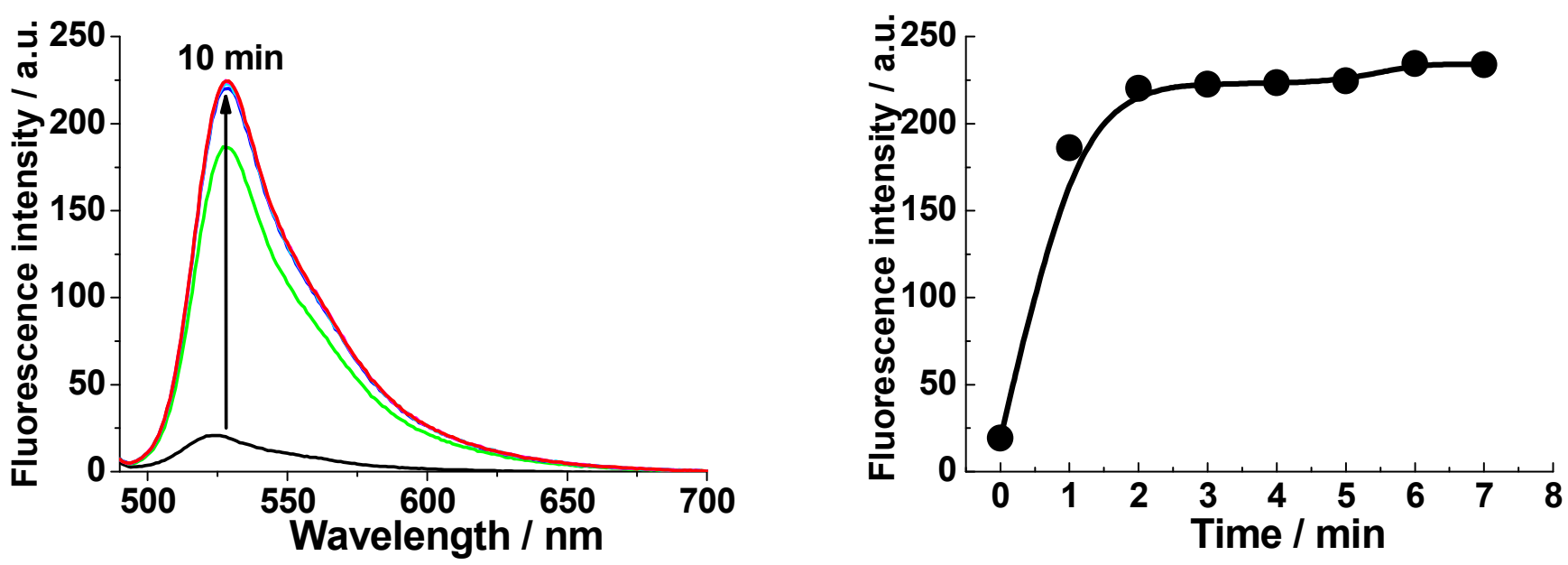

Figure S31. (left) Fluorescence turn-on response of $\boldsymbol{o - O H} / \mathrm{TEA} / \mathrm{DMAP}$ system upon addition of DCP (150 $\mathrm{mg} / \mathrm{L})$ in DMSO at $25^{\circ} \mathrm{C}$. The spectra were obtained every $1 \mathrm{~min}(0-8 \mathrm{~min})$ after the addition of DCP. Excited at $480 \mathrm{~nm}$. (right) Relative fluorescence intensity at $529 \mathrm{~nm}$ as a function of incubation time. $[\boldsymbol{o}-\mathbf{O H}]=10 \mu \mathrm{M}$. $[\mathrm{TEA}]=20 \mu \mathrm{M}$. [DMAP] $=10 \mu \mathrm{M}$. 

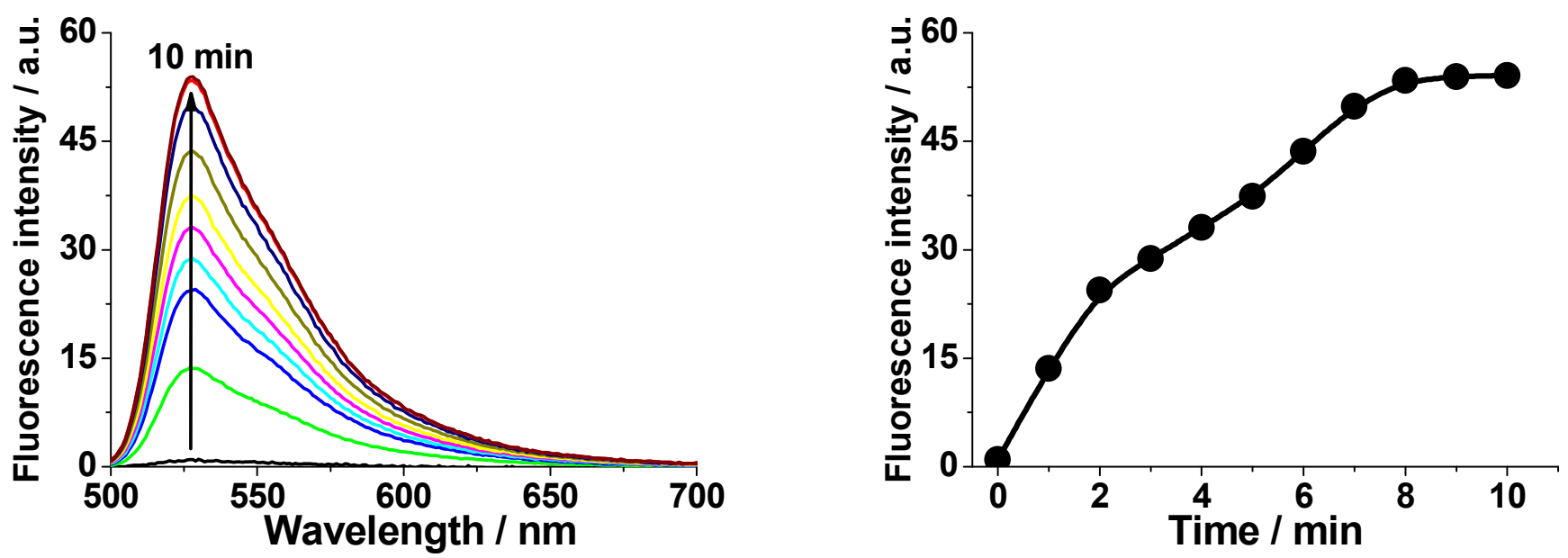

Figure S32. (left) Fluorescence turn-on response of $\boldsymbol{o - O H}$ /TEA/DMAP system upon addition of DCP (150 $\mathrm{mg} / \mathrm{L})$ in phosphate buffer $(10 \mathrm{mM}, \mathrm{pH} 7.4)$ containing $1 \% \mathrm{DMF}$ as a cosolvent at $25{ }^{\circ} \mathrm{C}$. The spectra were obtained every $1 \mathrm{~min}(0-8 \mathrm{~min})$ after the addition of DCP. Excited at $480 \mathrm{~nm}$. (right) Relative fluorescence intensity at $524 \mathrm{~nm}$ as a function of incubation time. $[\boldsymbol{o}-\mathbf{O H}]=10 \mu \mathrm{M}$. [TEA] $=20 \mu \mathrm{M}$. [DMAP] $=10 \mu \mathrm{M}$.

(f) Effect of pH on fluorescence response of o-OH toward DCP $(150 \mathrm{mg} / \mathrm{L})$ in aqueous media

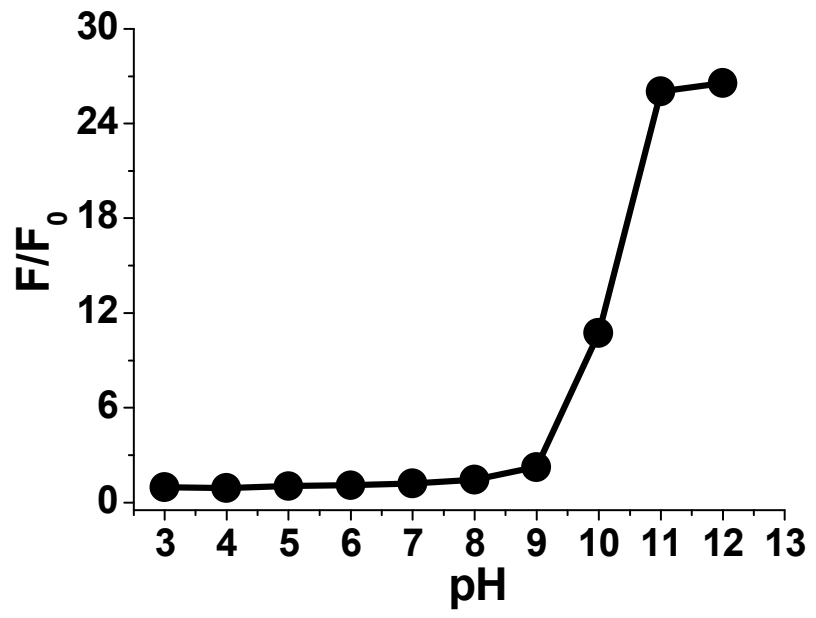

Figure S33. Fluorescence emission response of $\boldsymbol{o}-\mathbf{O H}(10 \mu \mathrm{M})$ upon treatment with DCP $(150 \mathrm{mg} / \mathrm{L})$ in buffer system at various $\mathrm{pH}$ (3 to 12). Excited at $480 \mathrm{~nm}$. 


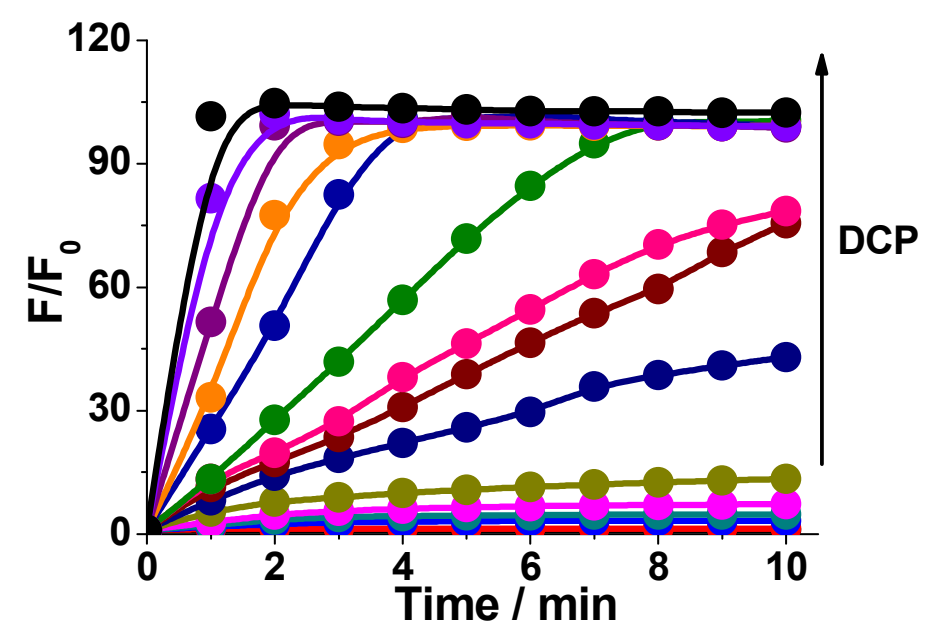

Figure S34. Fluorescence turn-on response of $\boldsymbol{o}-\mathbf{O H} / \mathrm{TEA} / \mathrm{DMAP}$ upon the reaction with different amounts of DCP (from bottom to top: 0, 0.1, 0.5, 1, 1.5, 3, 5, 10, 15, 25, 50, 75, 100, 150, $200 \mathrm{mg} / \mathrm{L}$ ) in DMF at $25^{\circ} \mathrm{C}$. The spectra were obtained every $1 \mathrm{~min}(0-10 \mathrm{~min})$ after the addition of DCP, and fluorescence intensity at $527 \mathrm{~nm}$ was measured with excitation at $480 \mathrm{~nm} .[\boldsymbol{o}-\mathbf{O H}]=10 \mu \mathrm{M}$. [TEA $]=20 \mu \mathrm{M}$. [DMAP] $=10 \mu \mathrm{M}$. 


\section{(h) Determination of detection limit of o-OH/TEA/DMAP toward DCP}

$\boldsymbol{o}-\mathbf{O H} / \mathrm{TEA} / \mathrm{DMAP}$ system was simply prepared by mixing $\boldsymbol{o}-\mathbf{O H}$, TEA, and DMAP in DMF at $25^{\circ} \mathrm{C}$. The fluorescence emission spectra of $\boldsymbol{o}-\mathbf{O H} / \mathrm{TEA} / \mathrm{DMAP}$ system in DMF were collected for 25 times to determine the background noise $\sigma$. Then fluorescence turn-on response of the $\boldsymbol{o}-\mathbf{O H} / \mathrm{TEA} / \mathrm{DMAP}$ to concentrations of DCP ranging from 0 to $200 \mathrm{mg} / \mathrm{L}$ upon incubation for $10 \mathrm{~min}$ were monitored (Figure S35). A linear regression curve was then fitted $\left(R^{2}=0.9982\right)$ according to fluorescence intensities at $527 \mathrm{~nm}$ as a function of amount of

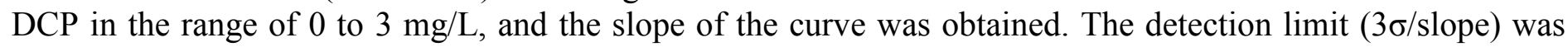
then determined to be $0.71 \mu \mathrm{g} / \mathrm{L}$.

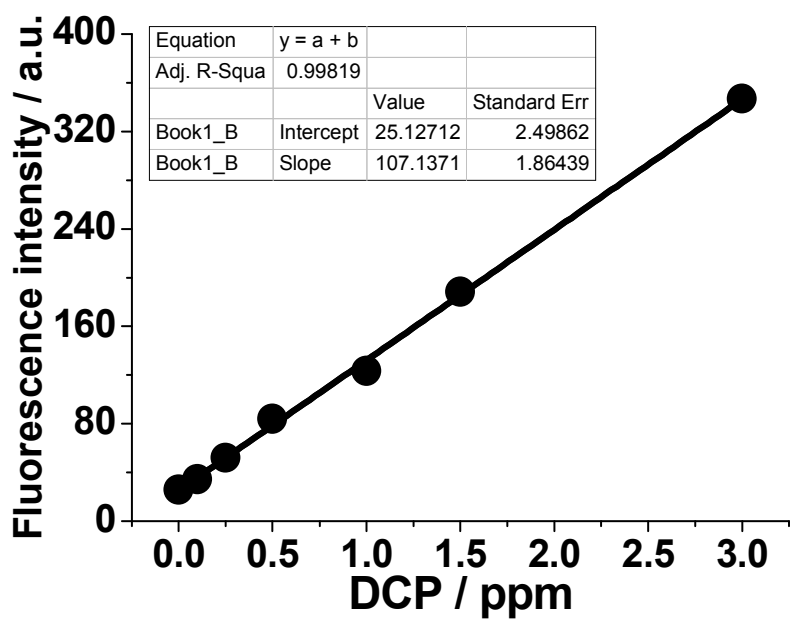

Figure S35. A linear relationship between fluorescence intensity at $527 \mathrm{~nm}$ and amounts of DCP $(0-3 \mathrm{mg} / \mathrm{L})$. Fluorescence intensity was measured $10 \mathrm{~min}$ after the addition of each DCP to $\boldsymbol{o}-\mathbf{O H} / \mathrm{TEA} / \mathrm{DMAP}$ system in $\mathrm{DMF}$ at $25^{\circ} \mathrm{C}$. Excited at $480 \mathrm{~nm} .[\boldsymbol{o}-\mathbf{O H}]=10 \mu \mathrm{M}$. [TEA $]=20 \mu \mathrm{M}$. [DMAP] $=10 \mu \mathrm{M}$. 
Under the pseudo first-order kinetics condition, rate constant $(k)$ was determined for the reaction between $\boldsymbol{o - O H}$ $(10 \mu \mathrm{M})$ and DCP $(150 \mathrm{mg} / \mathrm{L})$ in DMF containing TEA $(20 \mu \mathrm{M})$ and DMAP $(10 \mu \mathrm{M})$ at $25^{\circ} \mathrm{C}$, by monitoring the fluorescence intensity at $527 \mathrm{~nm}\left(\lambda_{\text {exc }}=480 \mathrm{~nm}\right)$ and fitting the fluorescence intensities to the pseudo firstorder equation 1:

$$
\ln \left[\left(\mathrm{F}_{\max }-\mathrm{F}_{\mathrm{t}}\right) / \mathrm{F}_{\max }\right]=-k_{\text {obs }} t \quad \text { eq. } 1
$$

where $F_{t}$ is the fluorescence intensity at $527 \mathrm{~nm}$ at each time interval $(\mathrm{t})$ measured and $\mathrm{F}_{\max }$ is the maximum fluorescence intensity obtained after the reaction was completed. $k_{\text {obs }}$ is the observed rate constant. Figure S36 is the pseudo first-order plot for the reaction of $\boldsymbol{o - O H} / \mathrm{TEA} / \mathrm{DMAP}$ system with DCP $(150 \mathrm{mg} / \mathrm{L})$. The negative slope of the plot provides the observed rate constant $\left(k_{\text {obs }}\right)$ with value of $0.0276 \mathrm{~s}^{-1}$. Therefore the half-life was calculated $\left(t_{1 / 2}=\ln 2 / k\right)$ to be approximately $25 \mathrm{~s}$ for DCP $(150 \mathrm{mg} / \mathrm{L})$.

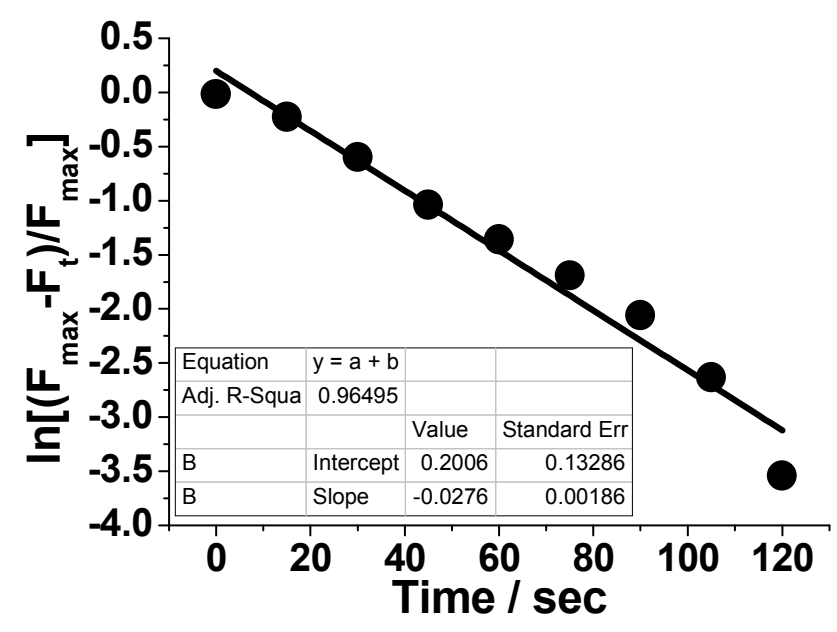

Figure S36. Pseudo first-order kinetic plot for the fluorescence turn-on response of $\boldsymbol{o}-\mathbf{O H} / \mathrm{TEA} / \mathrm{DMAP}$ upon the reaction with DCP $(150 \mathrm{mg} / \mathrm{L})$ in DMF at $25^{\circ} \mathrm{C}$. The spectra were obtained every $20 \mathrm{sec}(0-120 \mathrm{sec})$ after the addition of DCP, and fluorescence intensity at $527 \mathrm{~nm}$ was measured with excitation at $480 \mathrm{~nm}$. $[\boldsymbol{o}-\mathbf{O H}]=$ $10 \mu \mathrm{M} .[\mathrm{TEA}]=20 \mu \mathrm{M} .[\mathrm{DMAP}]=10 \mu \mathrm{M}$. 


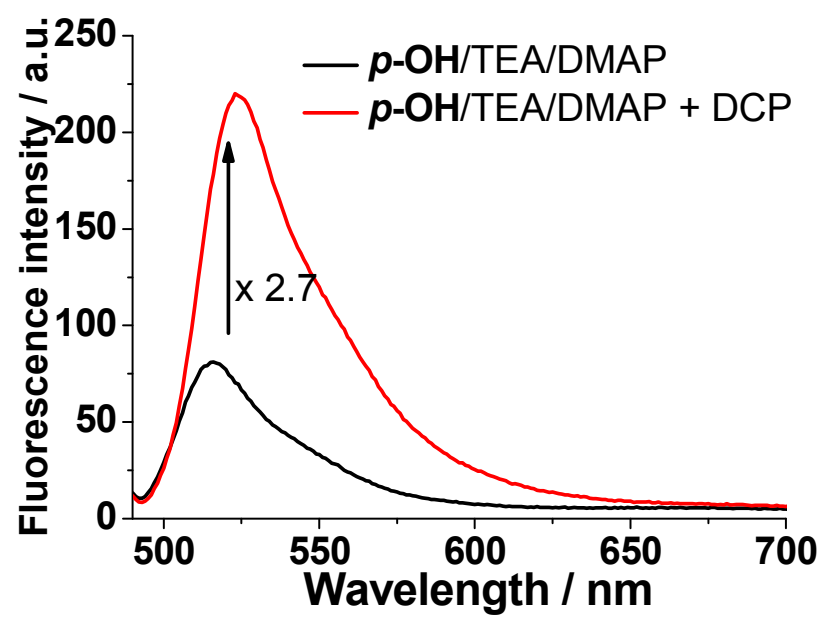

Figure S37. Fluorescence response of $\boldsymbol{p}-\mathbf{O H}(10 \mu \mathrm{M})$ upon addition of DCP $(150 \mathrm{mg} / \mathrm{L})$ in DMF containing TEA $(20 \mu \mathrm{M})$ and DMAP $(10 \mu \mathrm{M})$. Excited at $480 \mathrm{~nm}$. The spectrum was obtained 10 min after the addition of DCP to $\boldsymbol{p}$-OH/TEA/DMAP in DMF at $25^{\circ} \mathrm{C}$.

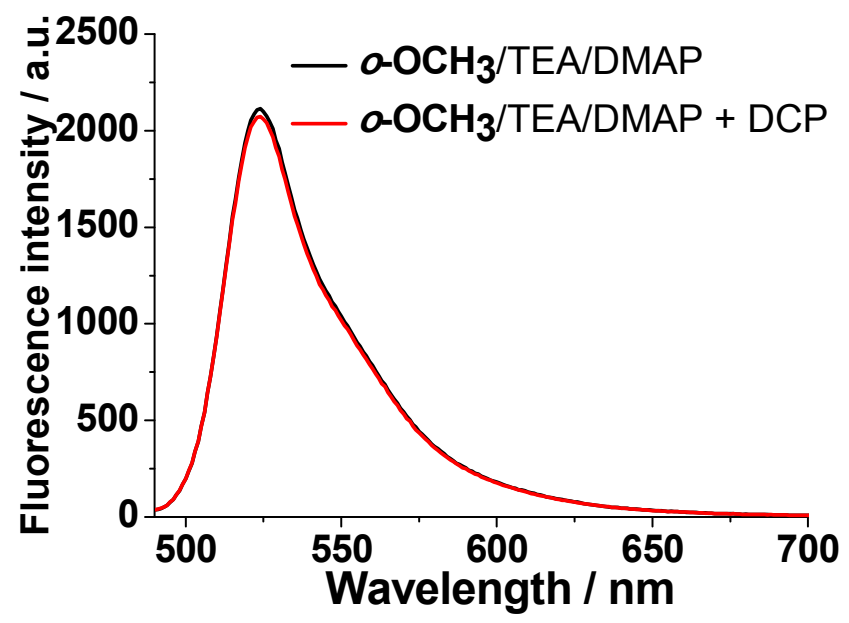

Figure S38. Fluorescence response of $\boldsymbol{o}-\mathbf{O C H}_{3}(10 \mu \mathrm{M})$ upon addition of DCP $(150 \mathrm{mg} / \mathrm{L})$ in DMF containing TEA $(20 \mu \mathrm{M})$ and DMAP $(10 \mu \mathrm{M})$. Excited at $480 \mathrm{~nm}$. The spectrum was obtained $10 \mathrm{~min}$ after the addition of DCP to $\boldsymbol{o}-\mathrm{OCH}_{3} / \mathrm{TEA} / \mathrm{DMAP}$ in DMF at $25^{\circ} \mathrm{C}$. 


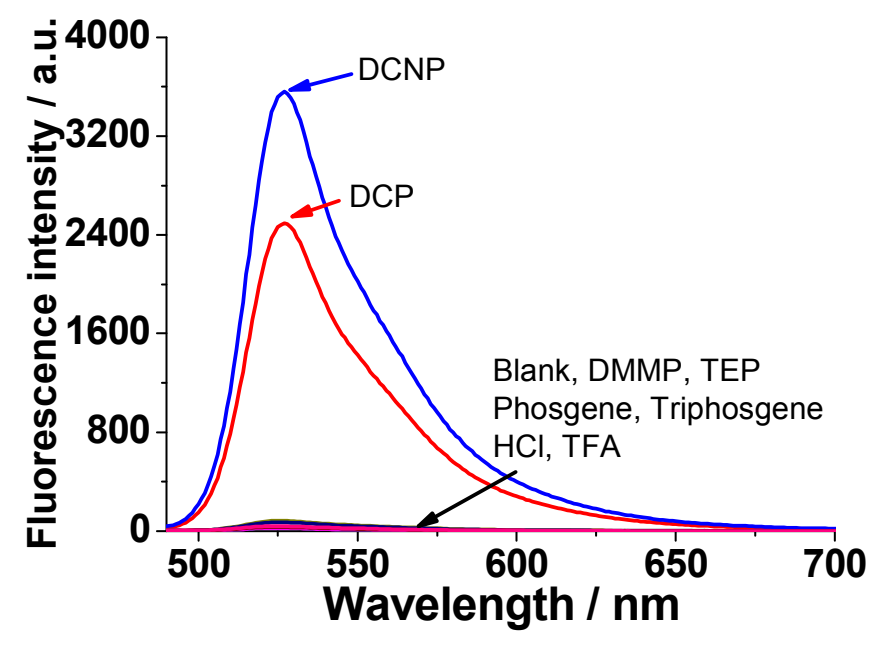

Figure S39. Fluorescence response of $\boldsymbol{o - O H} / \mathrm{TEA} / \mathrm{DMAP}$ system upon addition of various analytes in DMF. Excited at $480 \mathrm{~nm}$. The spectra were obtained $10 \mathrm{~min}$ after the addition of each analyte to $\boldsymbol{o}-\mathbf{O H} / \mathrm{TEA} / \mathrm{DMAP}$ system in DMF at $25^{\circ} \mathrm{C}$. [o-OH] $=10 \mu \mathrm{M}$. [TEA] $=20 \mu \mathrm{M}$. [DMAP] $=10 \mu \mathrm{M}$. [DCP] $=[\mathrm{DCNP}]=25 \mathrm{mg} / \mathrm{L}$; $[\mathrm{DMMP}]=[\mathrm{TEP}]=[$ phosgene $]=[$ triphosgene $]=100 \mathrm{mg} / \mathrm{L} ;[\mathrm{HCl}]=120 \mathrm{mM},[\mathrm{TFA}]=130 \mathrm{mM}$. 


\section{(l) Solid-phase applications}

$\boldsymbol{o}-\mathbf{O H} / \mathrm{TEA} / \mathrm{DMAP}$-coated paper was prepared by dropping $2 \mu \mathrm{L}$ of pre-mixed solution of $\boldsymbol{o}$-OH $(50 \mu \mathrm{M})$, TEA $(500 \mu \mathrm{M})$, and DMAP $(50 \mu \mathrm{M})$ in DMF, on a small piece of filter paper and drying under air. DCP vapor was prepared by charging DCP $(500 \mu \mathrm{L})$ in a cylindrical chamber $(\mathrm{O} . \mathrm{D}=4 \mathrm{~cm}$, height $=8 \mathrm{~cm})$, and then saturating over 8 hours with closed tightly a lid. The fluorescence change of $\boldsymbol{o - O H} / \mathrm{TEA} / \mathrm{DMAP}$-coated paper upon exposure to DCP vapor was observed under $365 \mathrm{~nm}$ UV light illumination.

(a)

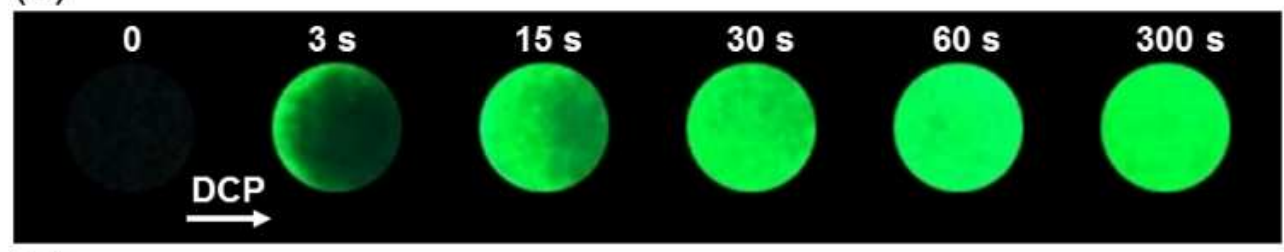

(b)

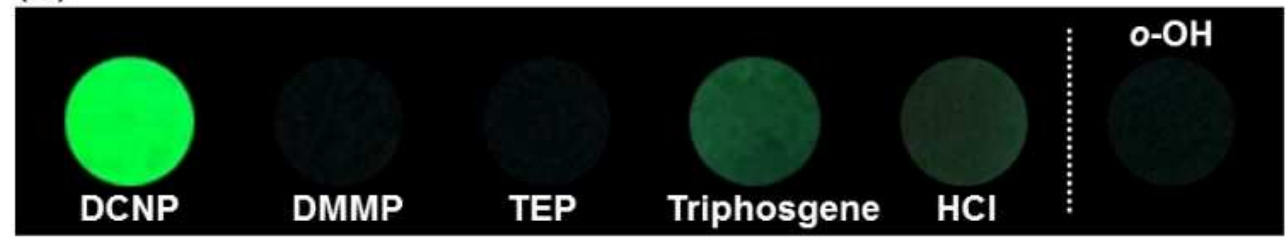

Figure S40. (a) Photographs of time-dependent emission changes of filter papers impregnated with $\boldsymbol{o}$ OH/TEA-DMAP upon exposure to DCP vapor for (left to right) $0,3 \mathrm{~s}, 15 \mathrm{~s}, 30 \mathrm{~s}, 60 \mathrm{~s}$, and $300 \mathrm{~s}$ upon irradiation at $365 \mathrm{~nm}$. (b) Photographs of emission changes of filter paper impregnated with o-OH/TEADMAP upon exposure to DCNP (208 ppm (v/v)), DMMP (1579 ppm (v/v)), TEP (517 ppm (v/v)), triphosgene $(342 \mathrm{ppm}(\mathrm{v} / \mathrm{v})), \mathrm{HCl}(250,000 \mathrm{ppm}(\mathrm{v} / \mathrm{v}))$ vapors, respectively, for $1 \mathrm{~min}$. The filter paper prepared with only $\boldsymbol{o}-\mathbf{O H}$ in the absence of TEA-DMAP in DMF is shown in the last as a control.

(a) o-OH/TEA-DMAP-DMF

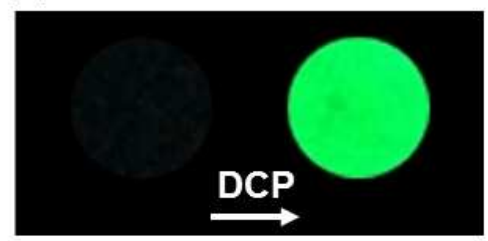

(b) o-OH/TEA-DMAP- $\mathrm{CH}_{2} \mathrm{Cl}_{2}$

vs.

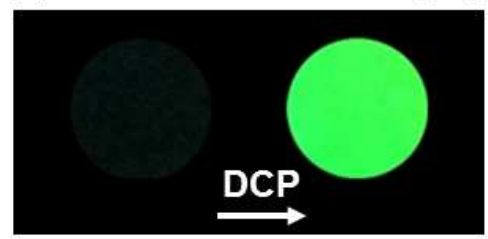

Figure S41. Comparison of photographs of filter papers impregnated with (a) $\boldsymbol{o}-\mathbf{O H} / \mathrm{TEA}-\mathrm{DMAP}-\mathrm{DMF}$ and (b) $\boldsymbol{o}-\mathbf{O H} / \mathrm{TEA}-\mathrm{DMAP}-\mathrm{CH}_{2} \mathrm{Cl}_{2}$ before (left) and after (right) DCP vapor (132 ppm (v/v)) for $1 \mathrm{~min}$, respectively, upon irradiation at $365 \mathrm{~nm}$. The filter paper was prepared by depositing with $\boldsymbol{o}$-OH/TEADMAP in (a) DMF and (b) $\mathrm{CH}_{2} \mathrm{Cl}_{2}$, respectively, and air-drying. 
(a)

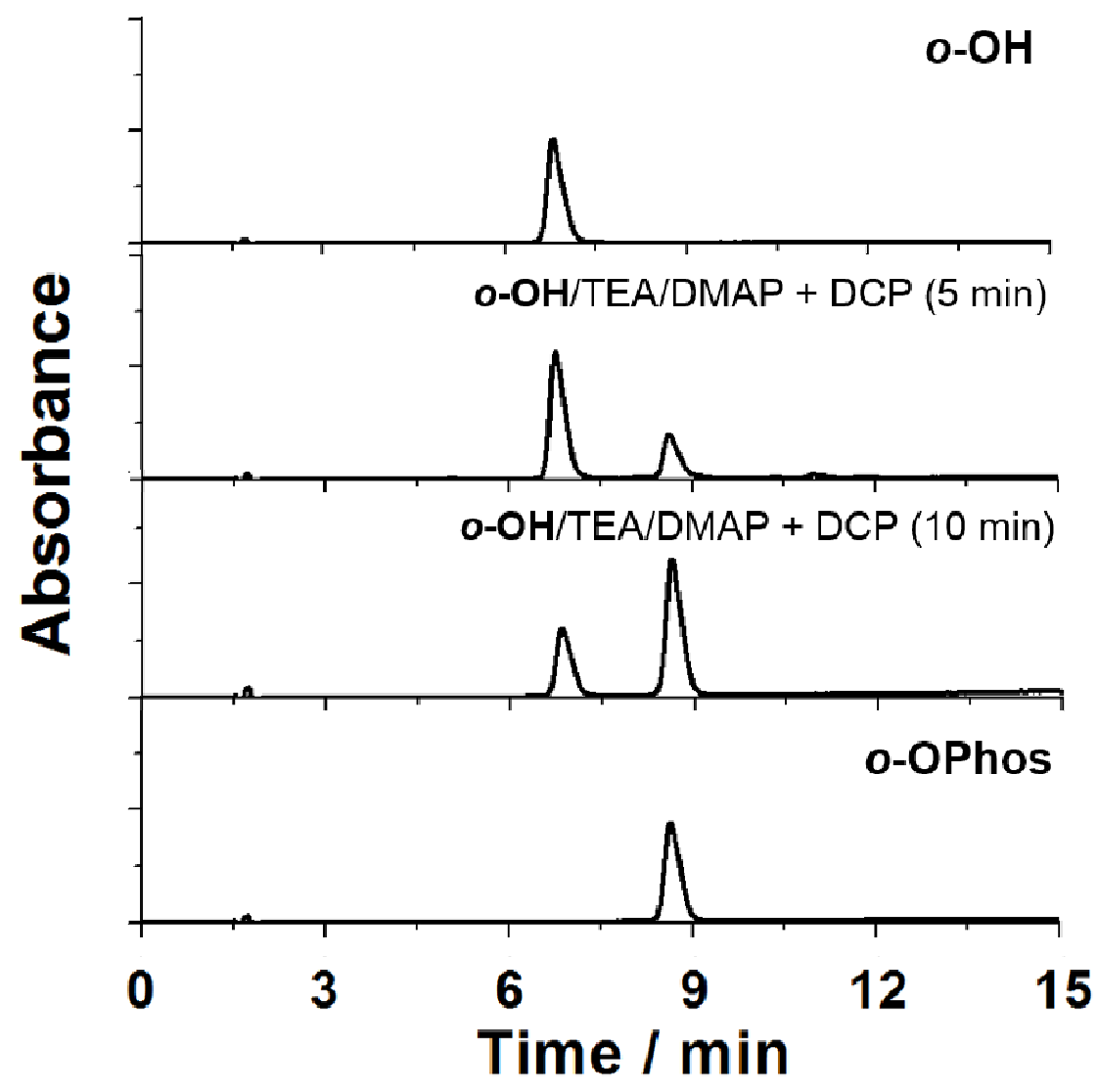

(b)

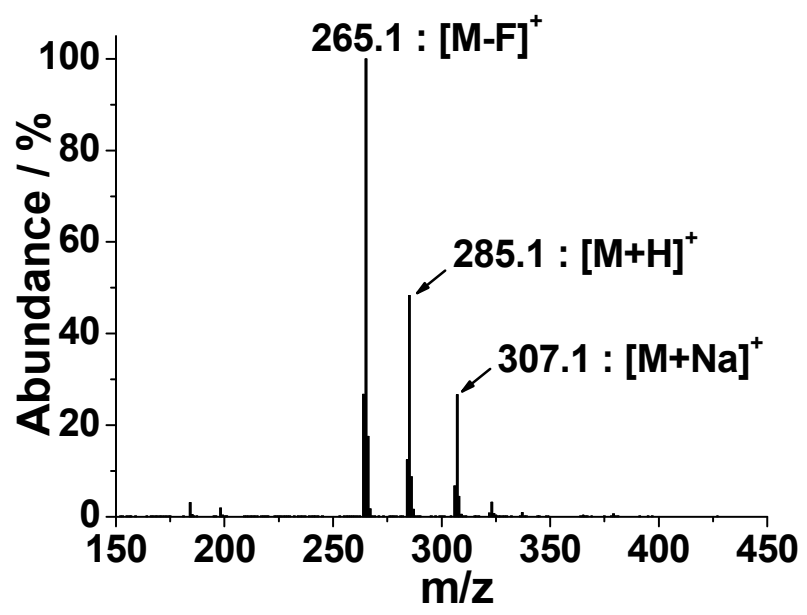

(c)

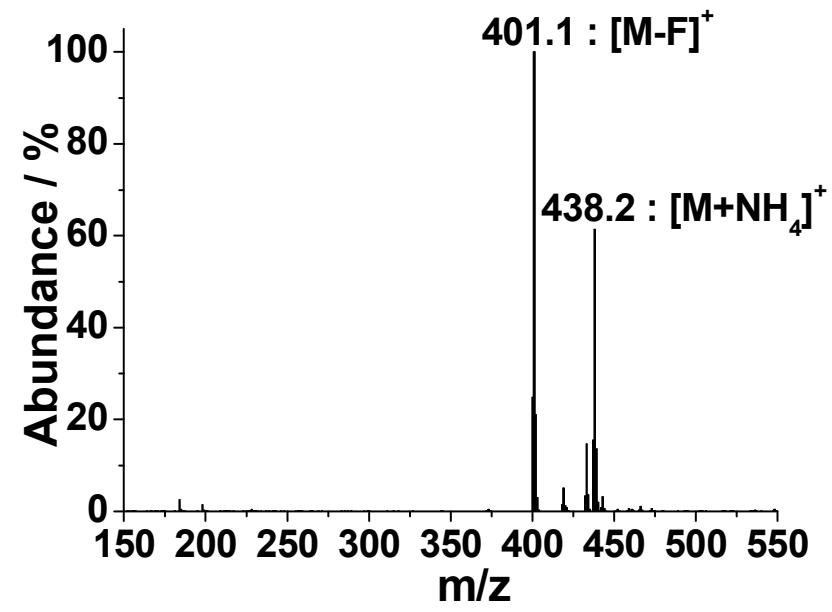

Figure S42. (a) HPLC chromatograms of $\boldsymbol{o}-\mathbf{O H}$ only (top); $\boldsymbol{o}-\mathbf{O H} / \mathrm{TEA} / \mathrm{DMAP}$ system upon treatment with DCP $(25 \mathrm{mg} / \mathrm{L})$ for $5 \mathrm{~min}$ and $10 \mathrm{~min}$ at $25{ }^{\circ} \mathrm{C}$, respectively (middle); $\boldsymbol{o}$-OPhos only (bottom). The samples were analyzed by LC-MS with a linear gradient elution (from 40 to $60 \% \mathrm{~B}, \mathrm{~A}$ : deionized water, B: methanol with $5 \mathrm{mM}$ ammonium formate, flow rate $0.3 \mathrm{~mL} / \mathrm{min}$, UV: $340 \mathrm{~nm}$ ). ESI-MS spectra of the peak of retention time at (b) $6.9 \mathrm{~min}$ and (c) $8.8 \mathrm{~min}$. MW of the retention time at $6.9 \mathrm{~min}$ is 285.1 , which corresponds to $[\mathrm{M}+\mathrm{H}]^{+}$for $\boldsymbol{o}-\mathbf{O H}$ and $\mathrm{MW}$ of the retention time at $8.8 \mathrm{~min}$ is 438.2 , which corresponds to $\left[\mathrm{M}+\mathrm{NH}_{4}\right]^{+}$for $\boldsymbol{o}$-OPhos. $[\boldsymbol{o}-\mathbf{O H}]=[\boldsymbol{o}$-OPhos $]=10 \mu \mathrm{M}$. $[\mathrm{TEA}]=20 \mu \mathrm{M}$. [DMAP] $=10 \mu \mathrm{M}$. 


\section{8. ${ }^{1}$ H-NMR and ${ }^{13}$ C-NMR Spectra}

${ }^{1} \mathrm{H}-\mathrm{NMR}$ spectrum of $\boldsymbol{o}-\mathbf{O H}$ in $\mathrm{CDCl}_{3}(400 \mathrm{MHz})$ :

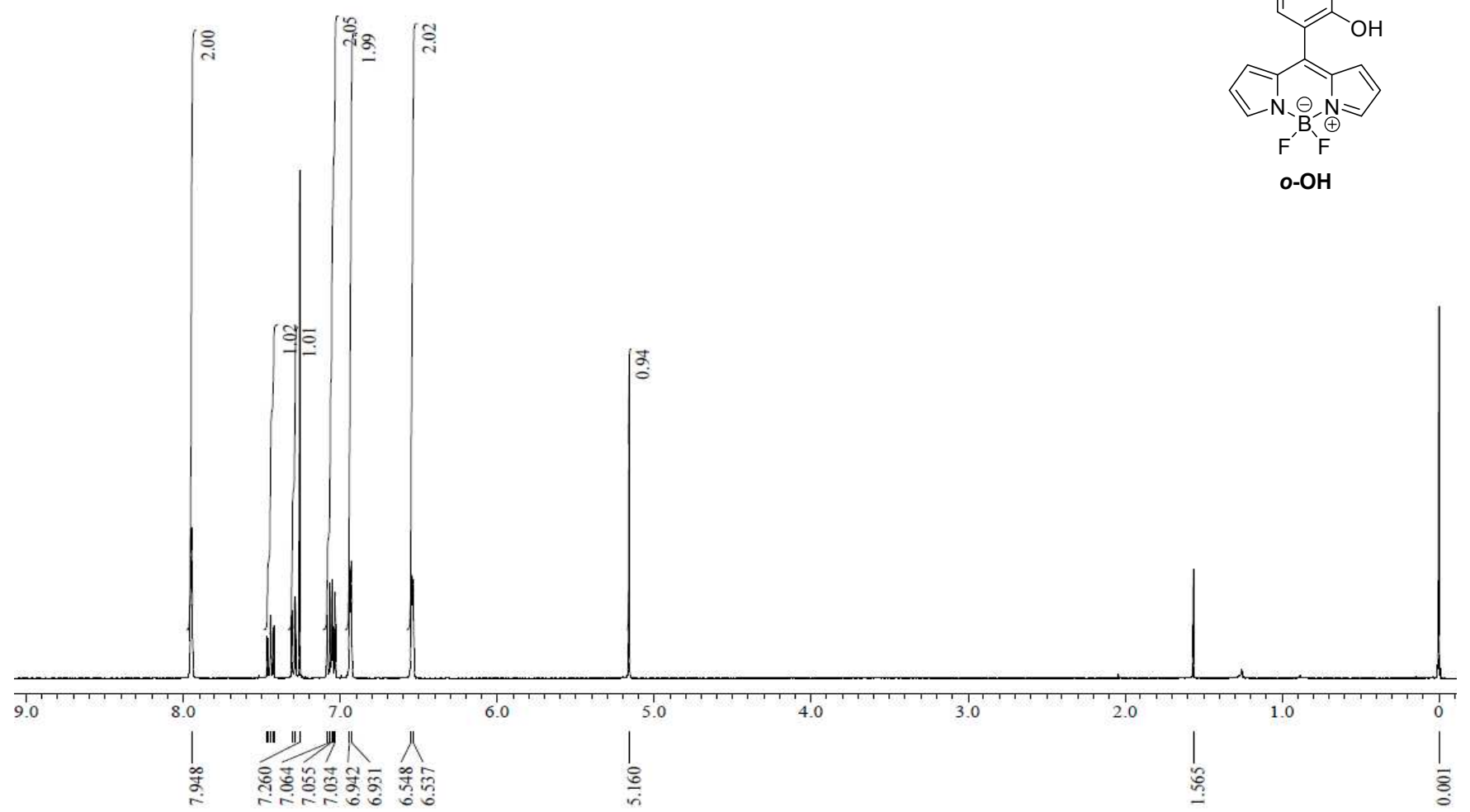

${ }^{13} \mathrm{C}-\mathrm{NMR}$ spectrum of $\boldsymbol{o}-\mathbf{O H}$ in $\mathrm{CDCl}_{3}(100 \mathrm{MHz})$ :

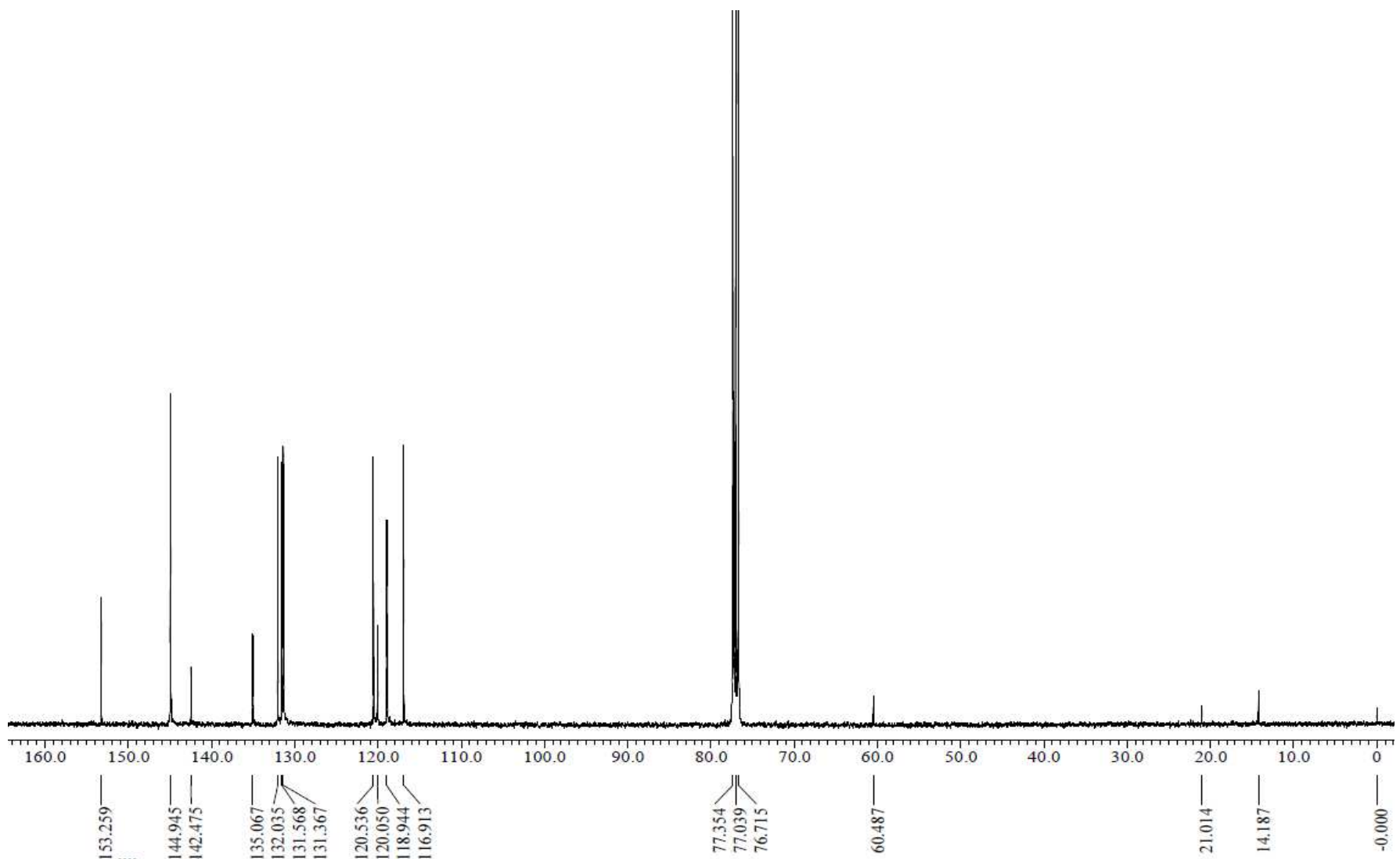


${ }^{1} \mathrm{H}-\mathrm{NMR}$ spectrum of $\boldsymbol{o}$-OPhos in $\mathrm{CDCl}_{3}(400 \mathrm{MHz})$ :

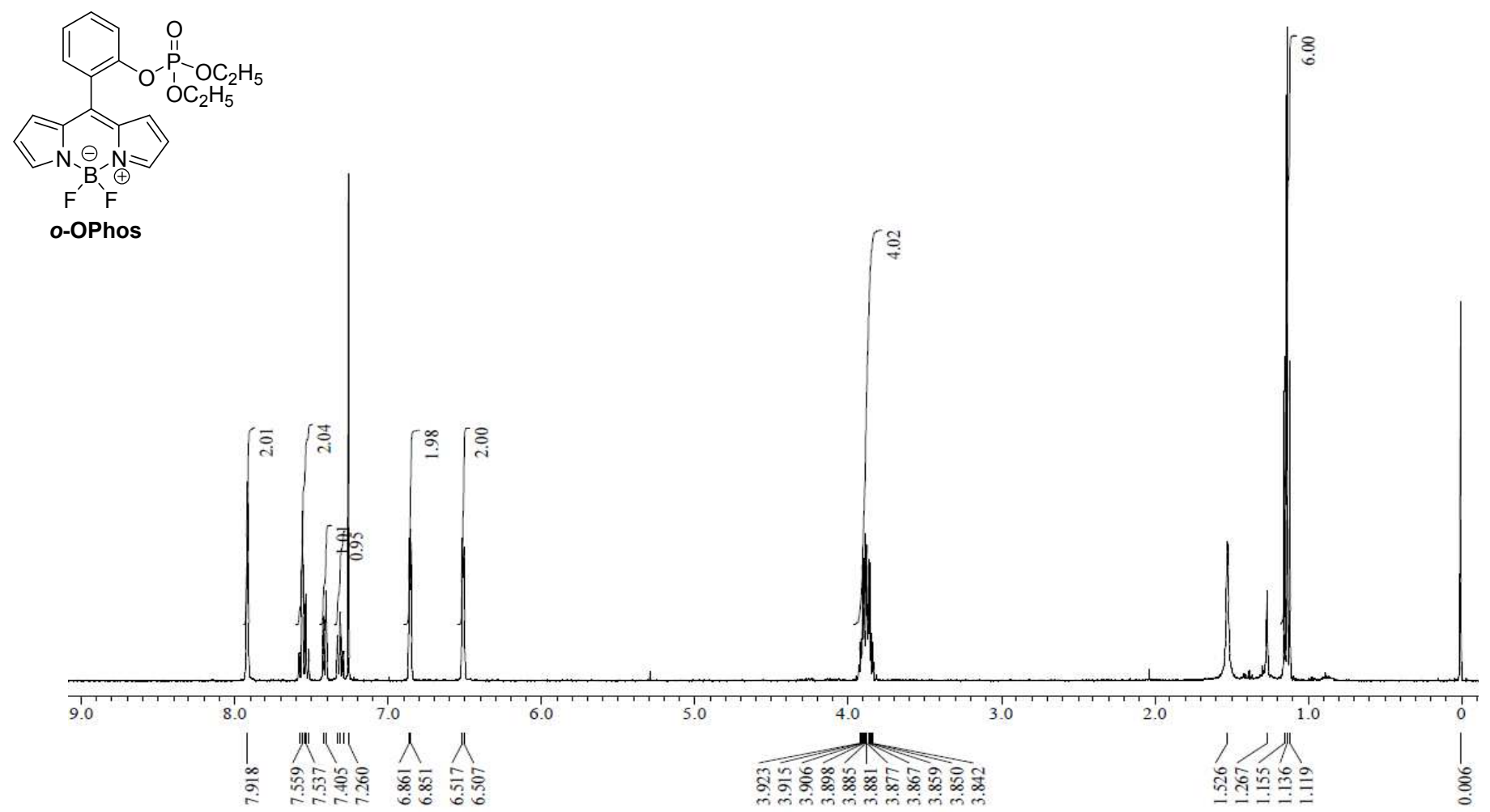

${ }^{13} \mathrm{C}$-NMR spectrum of $\boldsymbol{o}$-OPhos in $\mathrm{CDCl}_{3}(100 \mathrm{MHz})$ :

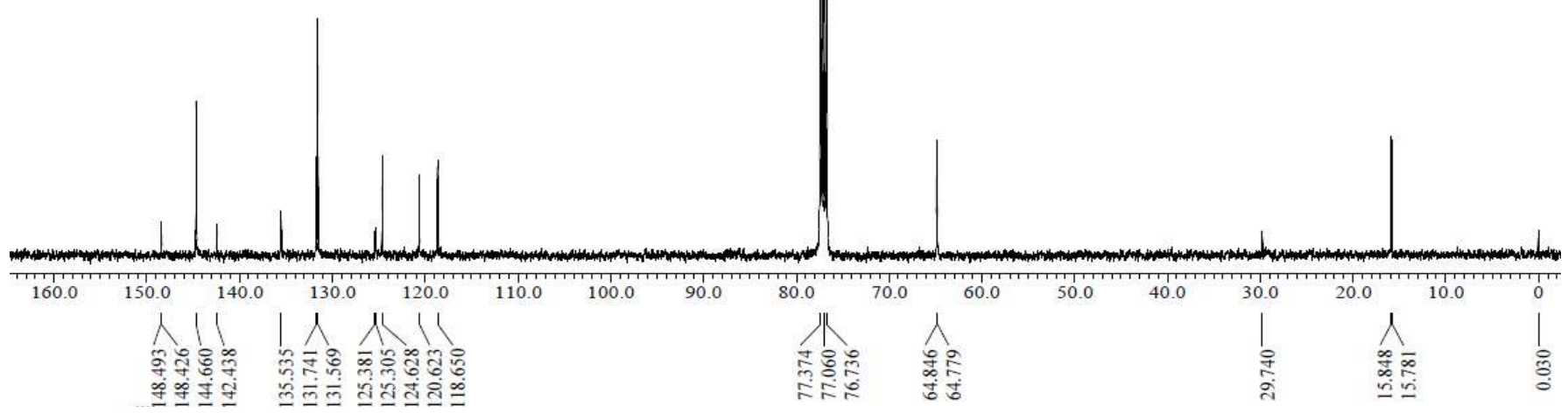


${ }^{1} \mathrm{H}-\mathrm{NMR}$ spectrum of $\boldsymbol{p}$-OH in $\mathrm{CDCl}_{3}(400 \mathrm{MHz})$ :

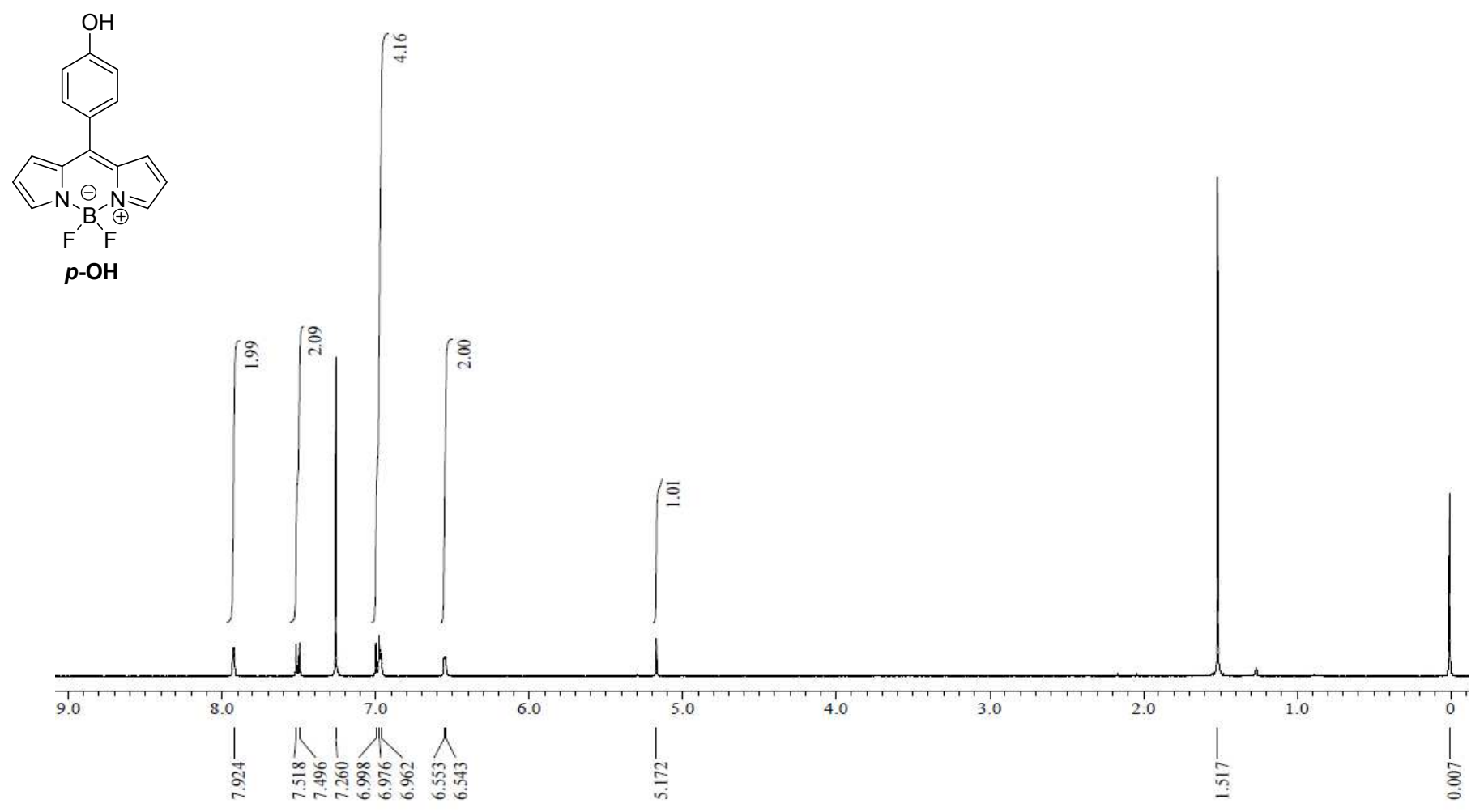

${ }^{13} \mathrm{C}$-NMR spectrum of $\boldsymbol{p}$-OH in $\mathrm{CDCl}_{3}(100 \mathrm{MHz})$ :

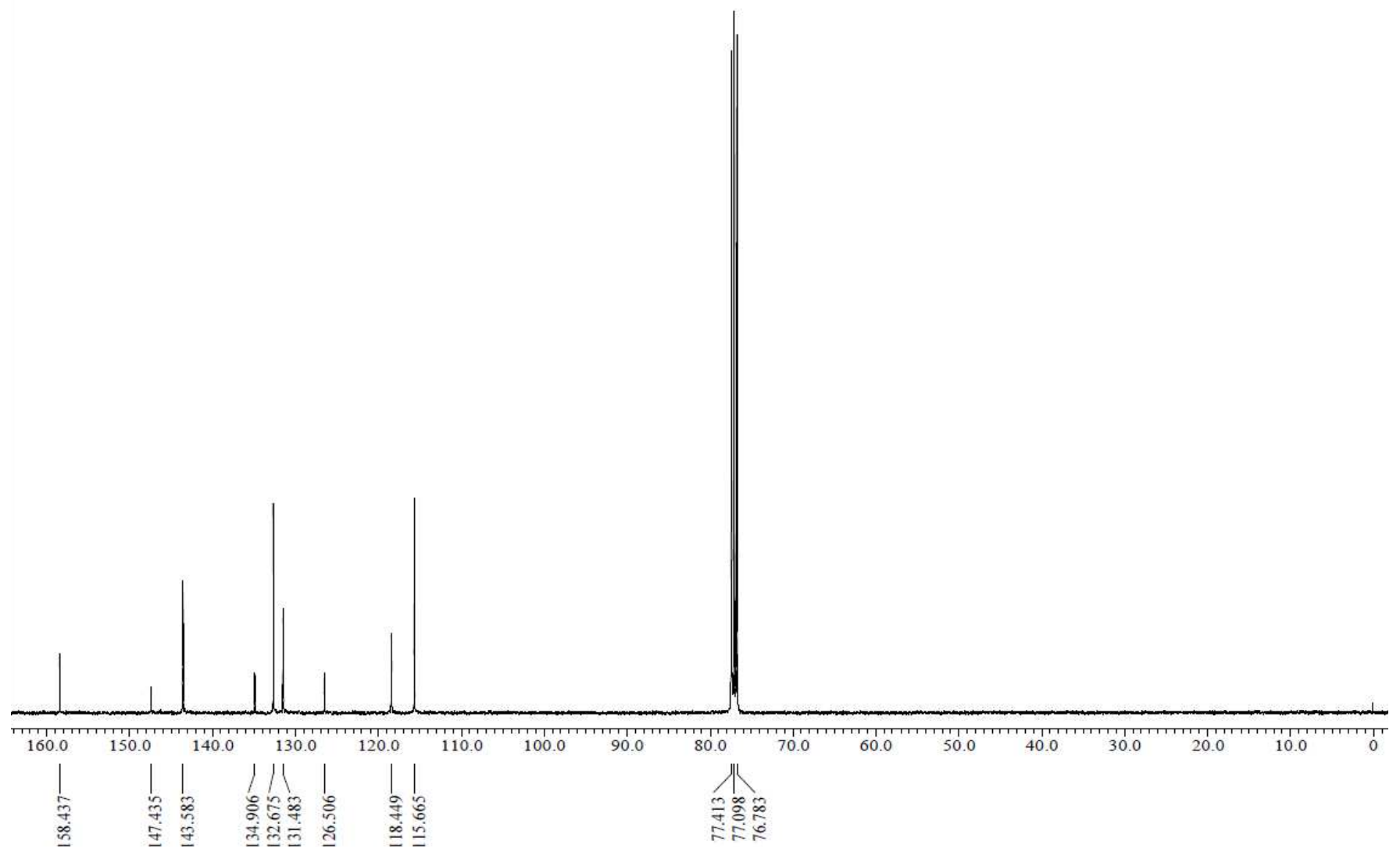


${ }^{1} \mathrm{H}-\mathrm{NMR}$ spectrum of $\boldsymbol{p}$-OPhos in $\mathrm{CDCl}_{3}(400 \mathrm{MHz})$ :

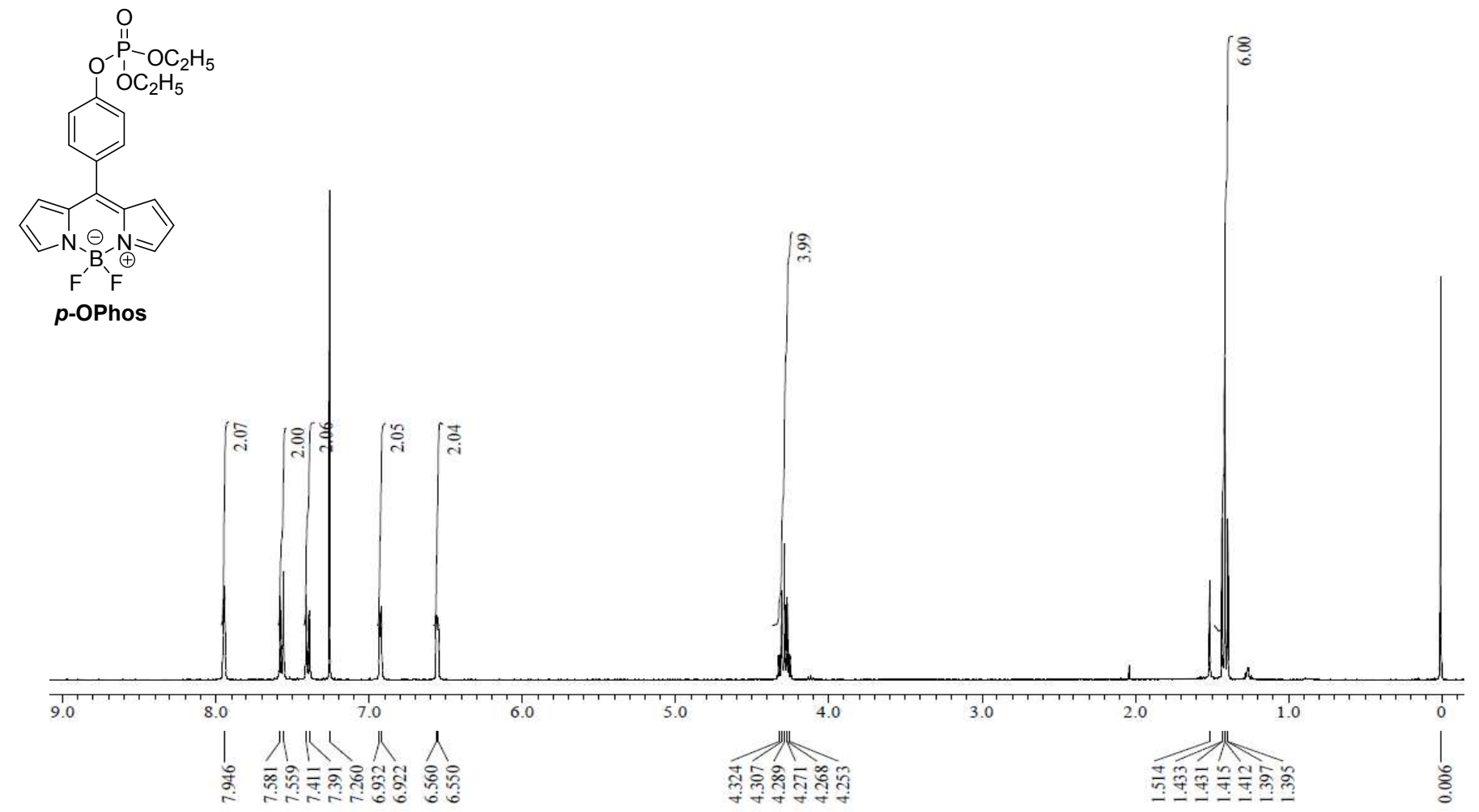

${ }^{13} \mathrm{C}$-NMR spectrum of $\boldsymbol{p}$-OPhos in $\mathrm{CDCl}_{3}(100 \mathrm{MHz})$ :

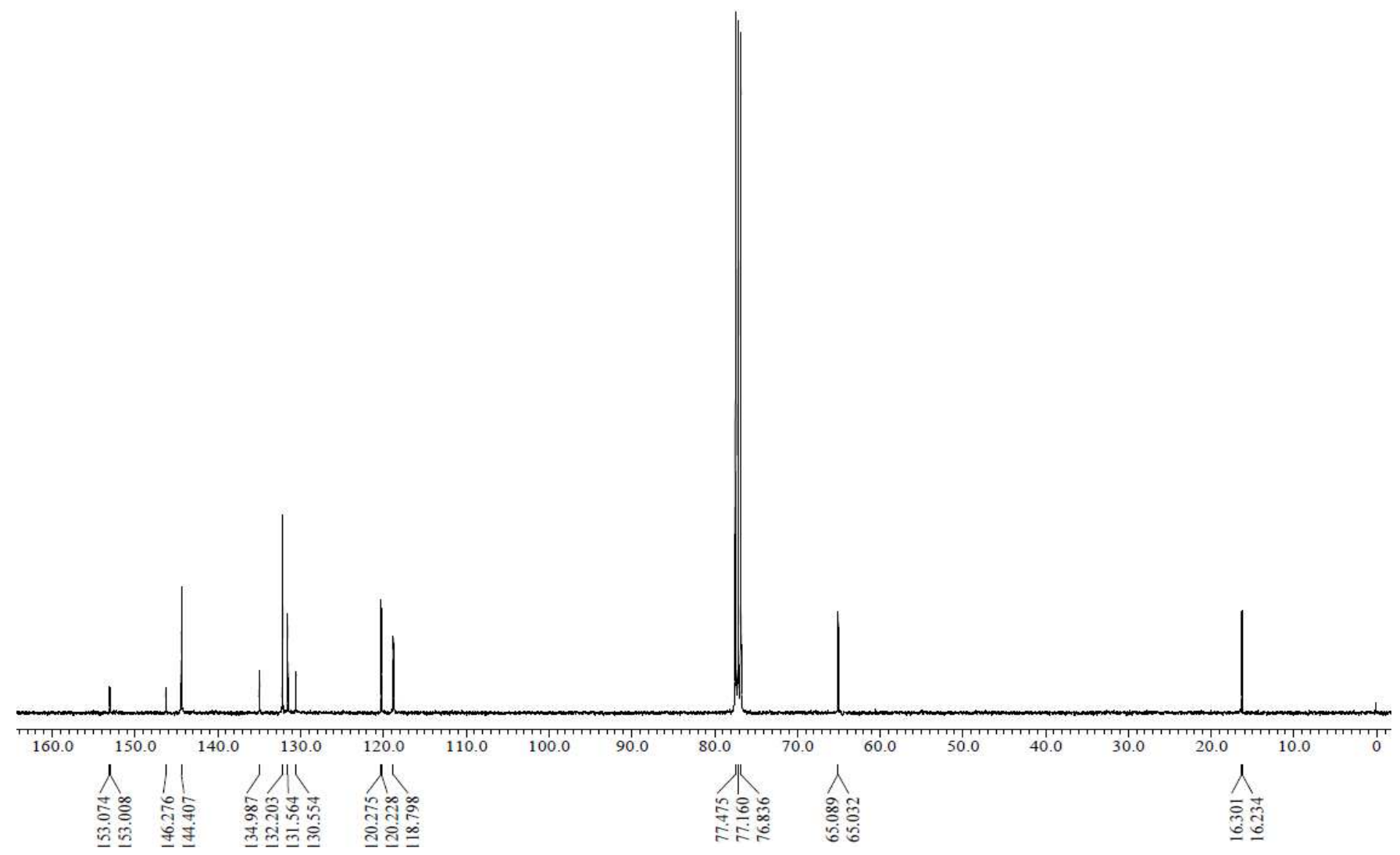


${ }^{1} \mathrm{H}-\mathrm{NMR}$ spectrum of $\boldsymbol{o}-\mathbf{O C H}_{3}$ in $\mathrm{CDCl}_{3}(400 \mathrm{MHz})$ :

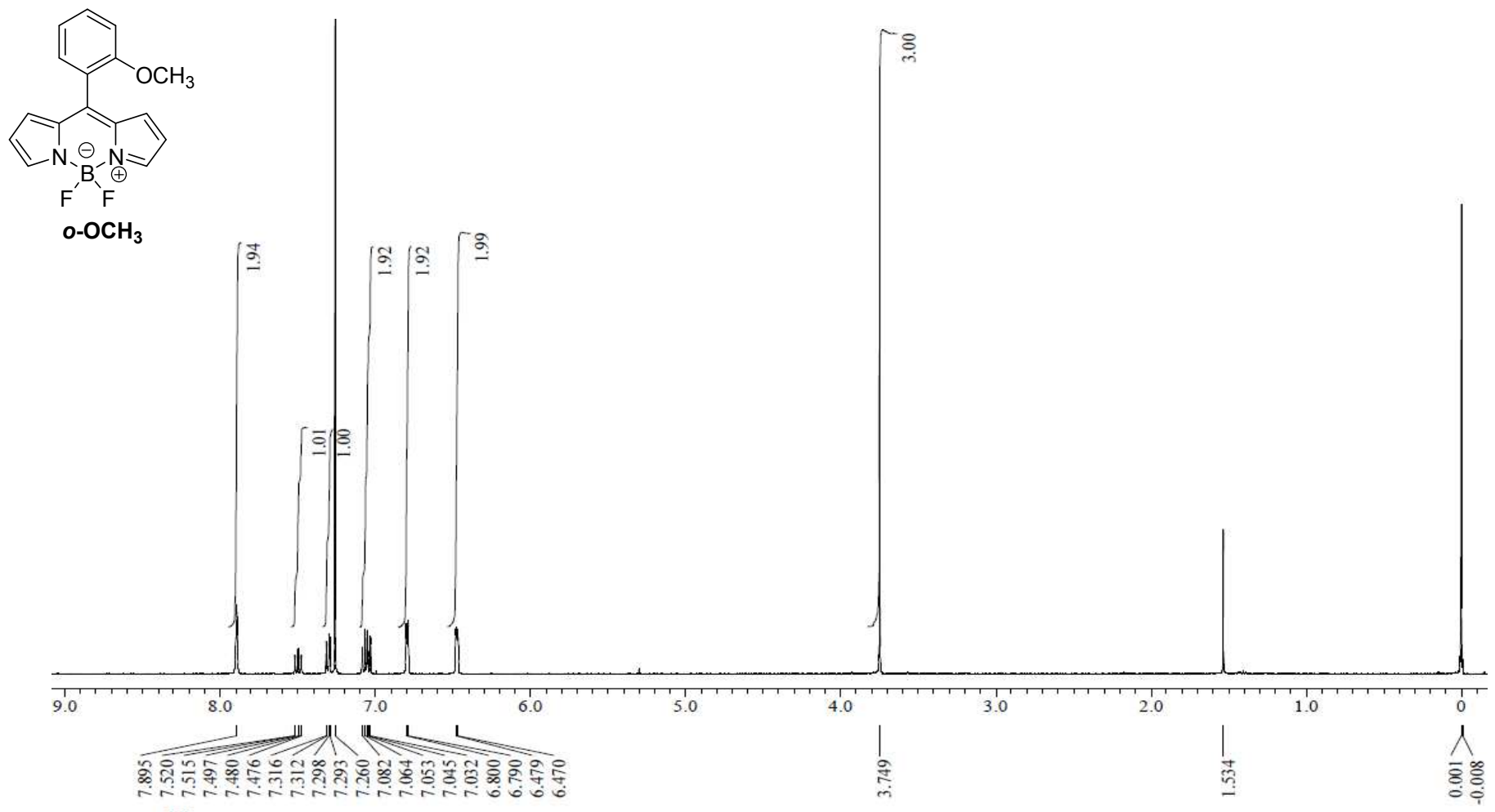

${ }^{13} \mathrm{C}-\mathrm{NMR}$ spectrum of $\boldsymbol{o}-\mathbf{O C H}_{3}$ in $\mathrm{CDCl}_{3}(100 \mathrm{MHz})$ :

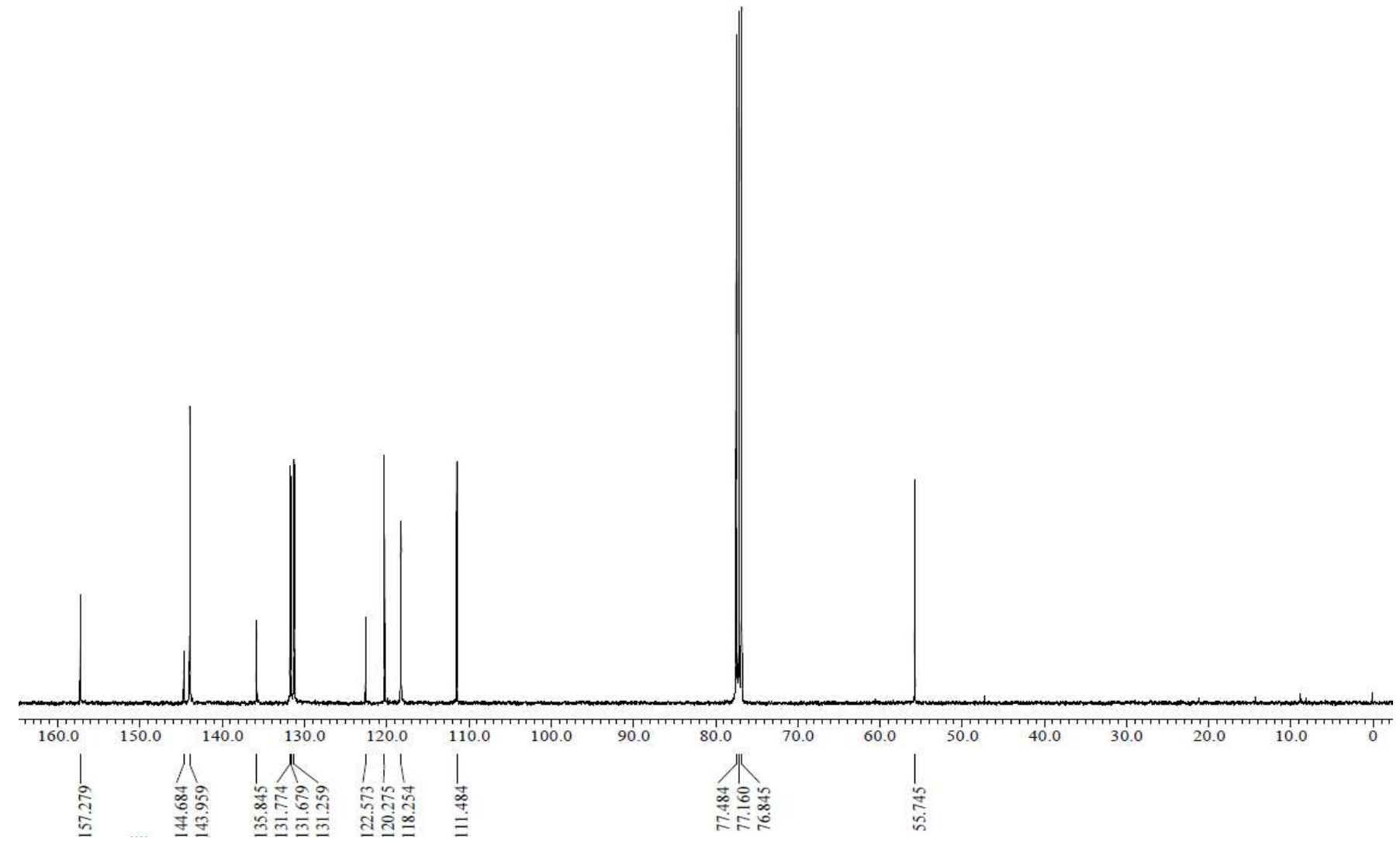




\section{References}

(1) Williams, A. T. R.; Winfield, S. A.; Miller, J. N. Analyst 1983, 108, 1067-1071.

(2) Rao, M. R.; Bolligarla, R.; Butcher, R. J.; Ravikanth, M. Inorg. Chem. 2010, 49, 10606-10616.

(3) (a) Kendall, J.; Monroe, K. P. J. Am. Chem. Soc. 1917, 39, 1787-1802; (b) Jouyban, A.; Khoubnasabjafari, M.; Vaez-Gharamaleki, Z.; Fekari, Z.; Acree, W. E., Jr. Chem. Pharm. Bull. 2005, 53, 519-523.

(4) Chung, P.-H. Advanced Fluorescence Lifetime Imaging and Spectroscopy Techniques for Biological Samples. Ph. D. Thesis, King's College London, U.K., March 2012.

(5) Förster, T.; Hoffmann, G. Z. Phys. Chem. 1971, 75, 63-76.

(6) For examples and discussion, see: (a) Haidekker, M. A.; Theodorakis, E. A. Org. Biomol. Chem. 2007, 5, 1669-1678; (b) Kuimova, M. K.; Yahiogly, G.; Levitt, J. A.; Suhling, K. J. Am. Chem. Soc. 2008, 130, 6672-6673; (c) Levitt, J. A.; Kuimova, M. K.; Yahioglu, G.; Chung, P.-H.; Suhling, K.; Phillips, D. J. Phys. Chem. C 2009, 113, 11634-11642; (d) Haidekker, M. A.; Theodorakis, E. A. J. Biol. Eng. 2010, 4, 11; (e) Howell, S.; Dakanali, M.; Theodorakis, E. A.; Haidekker, M. A. J. Fluoresc. 2012, 22, 457-465; (f) Wu, Y.; Stefl, M.; Olzynska, A.; Hof, M.; Yahioglu, G.; Yip, P.; Casey, D. R.; Ces, O.; Humpolickova, J.; Kuimova, M. K. Phys. Chem. Chem. Phys. 2013, 15, 14986-14933; (g) Haidekker, M. A.; Thedorakis, E. A. J. Mater. Chem. C 2016, 4, 2707-2718.

(7) Gaussian 09, Revision C.01, Frisch, M. J.; Trucks, G. W.; Schlegel, H. B.; Scuseria, G. E.; Robb, M. A.; Cheeseman, J. R.; Scalmani, G.; Barone, V.; Mennucci, B.; Petersson, G. A.; Nakatsuji, H.; Caricato, M.; Li, X.; Hratchian, H. P.; Izmaylov, A. F.; Bloino, J.; Zheng, G.; Sonnenberg, J. L.; Hada, M.; Ehara, M.; Toyota, K.; Fukuda, R.; Hasegawa, J.; Ishida, M.; Nakajima, T.; Honda, Y.; Kitao, O.; Nakai, H.; Vreven, T.; Montgomery, J. A., Jr.; Peralta, J. E.; Ogliaro, F., Bearpark, M.; Heyd, J. J.; Brothers, E.; Kudin, K. N.; Staroverov, V. N.; Keith, T.; Kobayashi, R.; Normand, J.; Raghavachari, K.; Rendell, A.; Burant, J. C.; Iyengar, S. S.; Tomasi, J.; Cossi, M.; Rega, N.; Millam, J. M.; Klene, M.; Knox, J. E.; Cross, J. B.; Bakken, V.; Adamo, C.; Jaramillo, J.; Gomperts, R.; Stratmann, R. E.; Yazyev, O.; Austin, A. J.; Cammi, R.; Pomelli, C.; Ochterski, J. W.; Martin, R. L.; Morokuma, K.; Zakrzewski, V. G.; Voth, G. A.; Salvador, P.; Dannenberg, J. J.; Dapprich, S.; Daniels, A. D.; Farkas, O.; Foresman, J. B.; Ortiz, J. V.; Cioslowski, J.; Fox, D. J. Gaussian, Inc., Wallingford CT, 2010. 